\title{
Deep Resistivity Structure of Yucca Flat, Nevada Test Site, Nevada
}

Open-File Report 2006-1261 


\section{Deep Resistivity Structure of Yucca Flat, Nevada Test Site, Nevada}

By Theodore H. Asch, Brian D. Rodriguez, Jay A. Sampson, Erin L. Wallin, and Jackie M. Williams

Open-File Report 2006-1261 


\section{U.S. Department of the Interior DIRK KEMPTHORNE, Secretary

\author{
U.S. Geological Survey \\ P. Patrick Leahy, Acting Director
}

U.S. Geological Survey, Reston, Virginia: 2006

For product and ordering information:

World Wide Web: http://www.usgs.gov/pubprod

Telephone: 1-888-ASK-USGS

For more information on the USGS — the Federal source for science about the Earth,

its natural and living resources, natural hazards, and the environment:

World Wide Web: http://www.usgs.gov

Telephone: 1-888-ASK-USGS

Any use of trade, product, or firm names is for descriptive purposes only and does not imply endorsement by the U.S. Government.

Although this report is in the public domain, permission must be secured from the individual copyright owners to reproduce any copyrighted materials contained within this report.

Suggested citation:

Asch, T.H., Rodriguez, B.D., Sampson, J.A., Wallin, E.L., and Williams, J.M., 2006, Deep Resistivity Structure of Yucca Flat, Nevada Test Site, Nevada: U.S. Geological Survey Open-File Report 2006-1261, 88 p. 


\section{Contents}

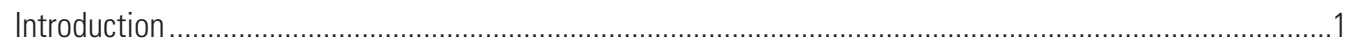

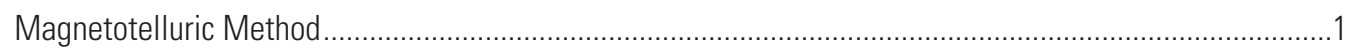

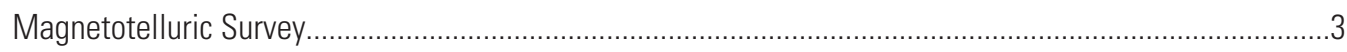

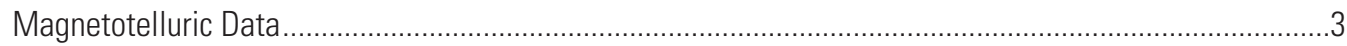

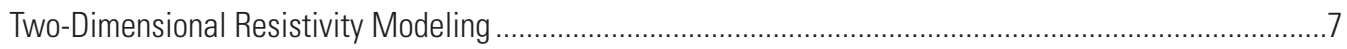

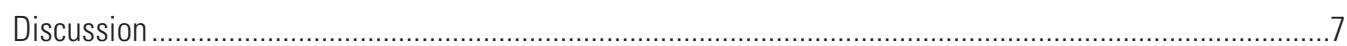

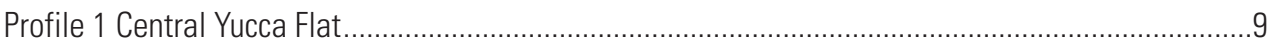

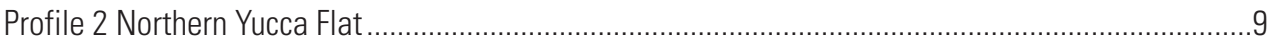

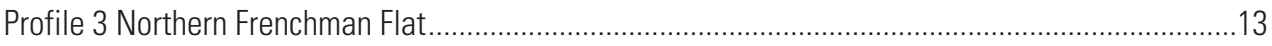

Profile 4 Southern Yucca Flat.................................................................................................... 13

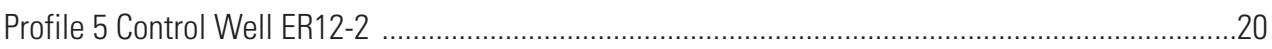

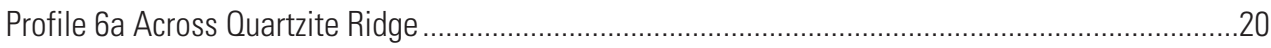

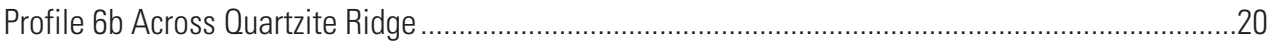

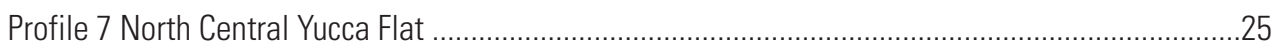

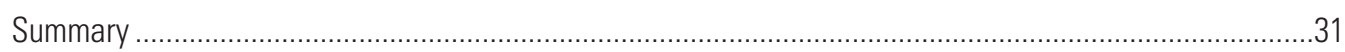

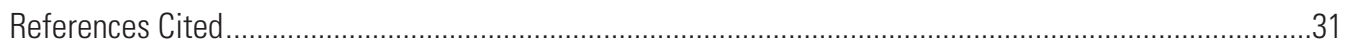

A. Profiles 1-7: Resistivity models, Apparent Resistivity, and Phase Data (fig. A1-A55) .........................33

\section{Figures}

1. Schematic image showing magnetotelluric (MT) stations in and near Yucca Flat, Nevada Test Site, Nevada

2. Schematic image showing magnetotelluric (MT) stations in and near Yucca Flat grouped into

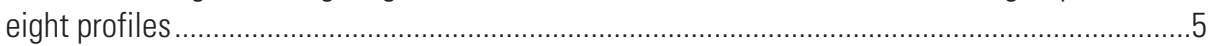

3. Hydrostratigraphic correlation chart for the Yucca Flat area .............................................

4. Profile 1, Model 128 with hydrogeologic interpretation ........................................................ 10

5. Profile 1, Model 129 with hydrogeologic interpretation ......................................................11

6. Profile 1, Model 130 with hydrogeologic interpretation ............................................................12

7. Profile 2, Model 48 with hydrogeologic interpretation ........................................................ 14

8. Profile 2, Model 51 with hydrogeologic interpretation .............................................................15

9. Profile 3, Model 92 with hydrogeologic interpretation .......................................................16

10. Profile 3, Model 93 with hydrogeologic interpretation .....................................................17

11. Profile 4, Model 53 with hydrogeologic interpretation .....................................................18

12. Profile 4, Model 60 with hydrogeologic interpretation ............................................................19

13. Profile 5, Model 24 with hydrogeologic interpretation .....................................................21

14. Profile 5, Model 31 with hydrogeologic interpretation ....................................................22

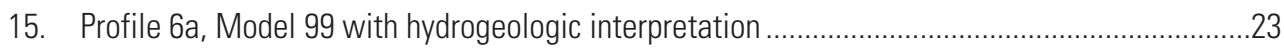

16. Profile 6a, Model 100 with hydrogeologic interpretation ........................................................24

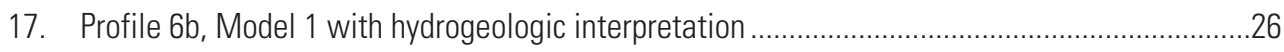

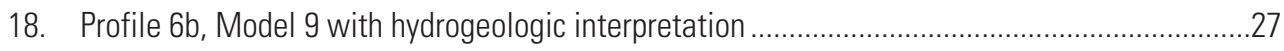

19. Profile 7, Model 44 with hydrogeologic interpretation ............................................................28

20. Profile 7, Model 51 with hydrogeologic interpretation .............................................................29

21. Profile 7, Model 52 with hydrogeologic interpretation ...........................................................30 


\section{Plate}

1. Geologic image of a portion of the Nevada Test Site illustrating locations of magnetotelluric data acquired in 2003

\section{Tables}

1. Magnetotelluric station locations and remote reference pairs...........................................

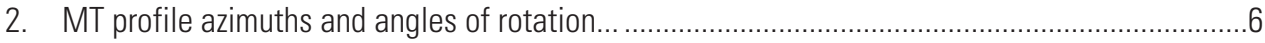

3. 2-D inversion (RLM2DI) and forward (PW2D) numerical model meshes for

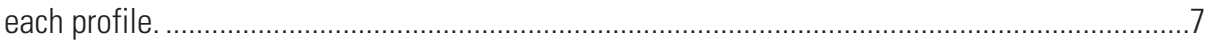

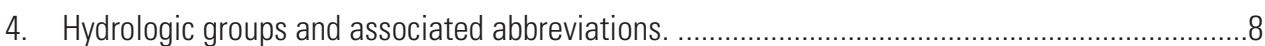

\section{Conversion Factors}

\begin{tabular}{lll}
\hline Multiply & By & To obtain \\
\hline inch (in.) & 2.54 & centimeter (cm) \\
inch (in.) & 25.4 & millimeter (mm) \\
foot (ft) & 0.3048 & meter (m) \\
mile (mi) & 1.609 & kilometer (km) \\
centimeter (cm) & 0.3937 & inch (in.) \\
millimeter (mm) & 0.03937 & inch (in.) \\
meter (m) & 3.281 & foot (ft) \\
kilometer $(\mathrm{km})$ & 0.6214 & mile (mi) \\
\hline
\end{tabular}

Vertical coordinate information is referenced to the World Geodetic System of 1984 (WGS 84).

Horizontal coordinate information is referenced to the North American Datum of 1983 (NAD 83).

Altitude, as used in this report, refers to distance above the vertical datum. 


\title{
Deep Resistivity Structure of Yucca Flat, Nevada Test Site, Nevada
}

\author{
By Theodore H. Asch, Brian D. Rodriguez, Jay A. Sampson, Erin L. Williams, and Jackie M. Williams
}

\section{Introduction}

The Department of Energy (DOE) and the National Nuclear Security Administration (NNSA) at their Nevada Site Office (NSO) are addressing groundwater contamination resulting from historical underground nuclear testing through the Environmental Management (EM) program and, in particular, the Underground Test Area (UGTA) project.

From 1951 to 1992,828 underground nuclear tests were conducted at the Nevada Test Site northwest of Las Vegas (U.S. Department of Energy, 2003). Most of these tests were conducted hundreds of feet above the groundwater table; however, more than 200 of the tests were near, or within, the water table. This underground testing was limited to specific areas of the Nevada Test Site including Frenchman Flat and Yucca Flat.

One issue of concern is the nature of the somewhat poorly constrained pre-Tertiary geology and its effects on ground-water flow in the area adjacent to a nuclear test. Ground-water modelers would like to know more about the hydrostratigraphy and geologic structure to support a hydrostratigraphic framework model that is under development for the Yucca Flat Corrective Action Unit (CAU) (Bechtel Nevada, 2006).

During 2003, the U.S. Geological Survey (USGS), supported by the DOE and NNSA-NSO, collected and processed data from 51 magnetotelluric (MT) and audio-magnetotelluric (AMT) stations at the Nevada Test Site in and near Yucca Flat (fig. 1) to assist in characterizing the pre-Tertiary geology in that area. This work will help to refine the character, thickness, and lateral extent of pre-Tertiary confining units. In particular, a major goal has been to define the upper clastic confining unit (UCCU - late Devonian - Mississippian-age siliciclastic rocks assigned to the Eleana Formation and Chainman Shale) in the Yucca Flat area. The MT and AMT data have been released in separate USGS Open File Reports (Williams and others, 2005a, 2005b, 2005c, 2005d, 2005e, and 2005f).

The Nevada Test Site magnetotelluric data interpretation presented in this report includes the results of detailed two-dimensional (2-D) resistivity modeling for each profile (including alternative interpretations) and gross inferences on the three-dimensional (3-D) character of the geology beneath each station.

\section{Magnetotelluric Method}

The MT method is a passive surface geophysical technique that uses the Earth's natural electromagnetic fields to investigate the electrical resistivity structure of the subsurface. The resistivity of geologic units is largely dependent upon their fluid content, porosity, degree of fracturing, temperature, and conductive mineral content (Keller, 1989). Saline fluids within pore spaces and fracture openings can reduce the resistivity of a resistive rock matrix. Resistivity also can be lowered by the presence of conductive clay minerals, carbon, and metallic mineralization. It is common for altered volcanic rocks to contain authigenic minerals that have resistivities that are one tenth of those of the surrounding rocks (Nelson and Anderson, 1992). Increased temperatures cause higher ionic mobility and mineral activation energy, reducing rock resistivities significantly. Unaltered, unfractured igneous rocks are moderately to highly resistive (hundreds to thousands of ohm-m), whereas fault zones will show low resistivity (less than $100 \mathrm{ohm}-\mathrm{m}$ ) when they are composed of rocks that are fractured enough to have hosted fluid transport and consequent mineralogical alteration (Eberhart-Phillips and others, 1995). Carbonate rocks are moderately to highly resistive (hundreds to thousands of ohm-m) depending upon their fluid content, porosity, fracturing, and impurities. Marine shales, mudstones, and clay-rich alluvium normally are conductive (a few ohm-m to tens of ohm-m). Unaltered metamorphic rocks (non-graphitic) are moderately to highly resistive (hundreds to thousands of ohm-m). Tables of electrical resistivity for a variety of rocks, minerals, and geological environments are included in Keller (1987) and Palacky (1987).

The MT method can be used to probe the Earth's crust from depths of tens of meters to tens of kilometers (Vozoff, 1991). Natural variations of the Earth's magnetic and electric field are measured and recorded at each MT station. The primary frequency bands used by the MT method include the 10,000 hertz $(\mathrm{Hz})$ to $1 \mathrm{~Hz}$ range using worldwide lightning activity as signal sources and the 1 to $0.0001 \mathrm{~Hz}$ range that measures signals due to geomagnetic micro-pulsations. The natural electromagnetic waves propagate vertically in the Earth because the large resistivity contrast between the air and the Earth causes a vertical refraction of the electromagnetic wave transmitted into the Earth (Vozoff, 1972). 


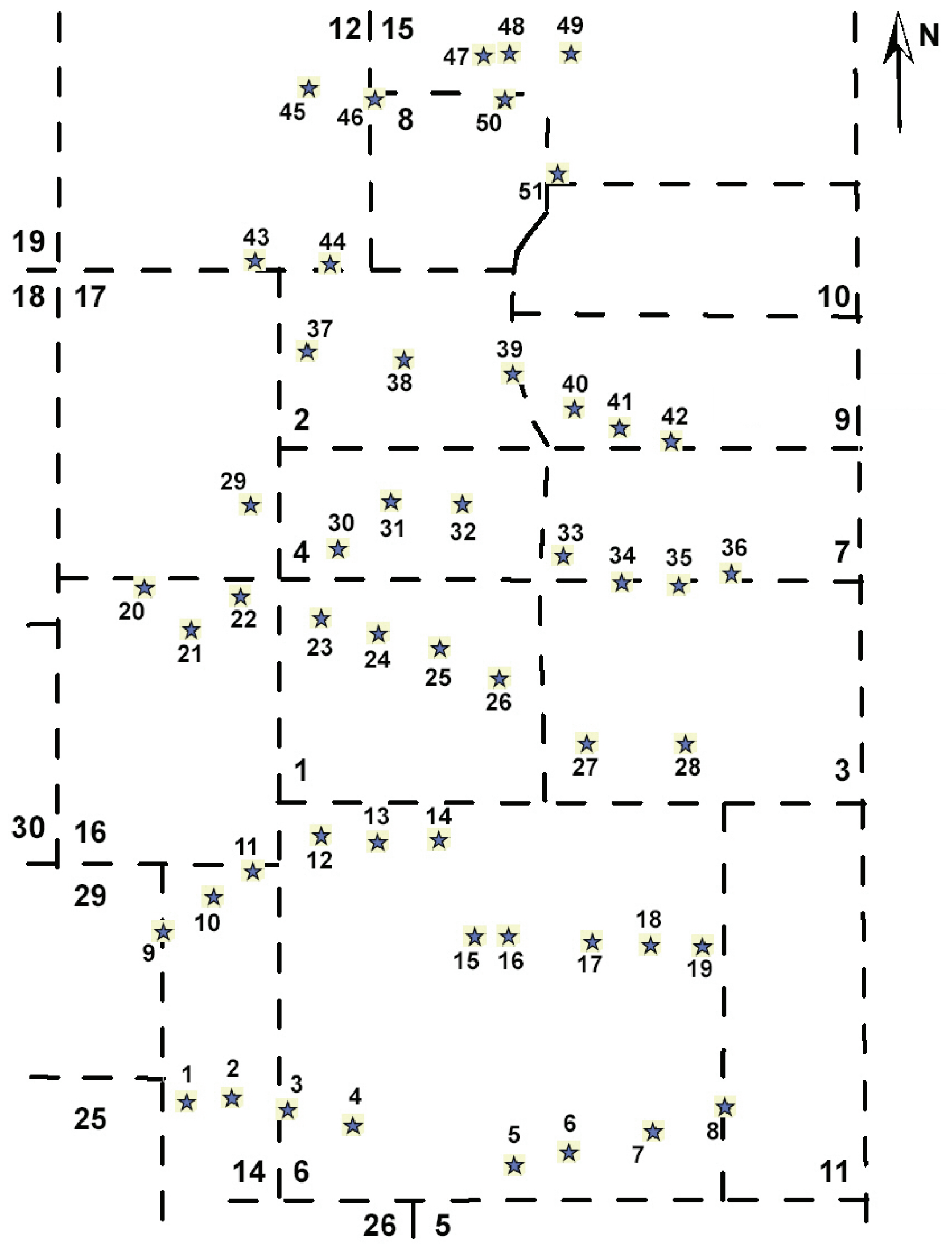

Figure 1. Schematic image showing magnetotelluric (MT) stations in and near Yucca Flat, Nevada Test Site, Nevada. MT stations acquired in 2003 are numbered stars 1-51. Dashed lines are boundaries of Nevada Test Site Areas 1-7, 9-12, 14-19, $25,26,29$, and 30 . 
The natural electric and magnetic fields are recorded in two orthogonal, horizontal directions and the vertical magnetic field component ("tipper") is also recorded. The resulting time-series signals are used to derive tensor apparent resistivities and phases. First, the signals are converted to complex cross-spectra using fast-fourier-transform (FFT) techniques. Then, a least-squares, cross-spectral analysis (Bendat and Piersol, 1971) is used to solve for a transfer function that relates the observed electric fields to the observed magnetic fields, with the assumption that the Earth consists of a two-input, two-output linear system. Prior to conversion to apparent resistivity and phase, the tensor is normally rotated. This rotation may be into principal directions that correspond to the direction of maximum and minimum apparent resistivity, or it may be made perpendicular to the survey traverse. For a 2-D Earth, in which the Earth's resistivity structure varies with depth and in one lateral direction, the MT fields can then be decoupled into transverse electric (TE) and transversemagnetic TM modes. Two-dimensional resistivity modeling is generally computed to fit both modes. When the geology satisfies the 2-D assumption and the MT survey is perpendicular to the geologic strike, the MT data for the TE mode represents the electric field parallel to geologic strike, and the data for the TM mode represents the electric field across strike. The MT method is well suited for studying complicated geological environments because the electric and magnetic relations are sensitive to vertical and horizontal variations in resistivity. The method is capable of establishing whether the electromagnetic fields are responding to subsurface rock bodies of effectively 1,2 , or 3 dimensions. An introduction to the MT method and references for a more advanced understanding are in Dobrin and Savit (1988) and Vozoff (1991).

\section{Magnetotelluric Survey}

Data were collected at 51 stations across the Yucca Flat Basin from October to December of 2003. The station locations were chosen to help constrain the geologic/hydrostratigraphic interpretation and were selected based on proximity to roads and to avoid, where possible, electrical noise from power lines and vehicles. The low frequency data $(0.0002$ to $200 \mathrm{~Hz}$ ) were collected with an Electromagnetic Instruments, Inc., (EMI) MT24/LF 24-bit system (EMI, 2002), and the high-frequency data (4 Hz to $23,000 \mathrm{~Hz}$ ) were collected with a portable EMI MT-1 system (EMI, 1996). Low-frequency horizontal electric fields were measured using three copper/copper sulfate porous pot electrodes placed in an L-shaped array with dipole lengths of 30 meters $(\mathrm{m})$. Titanium electrodes were used in a similar array for the high-frequency data acquisition. Orthogonal, horizontal magnetic fields in the direction of the electric-field measurement array were sensed using EMI's high-magnetic-permeability, mu-metal-cored BF-4 and BF-6 induction coils. For the low-frequency data, two single-station recordings of the orthogonal, horizontal components of the electric and magnetic fields and the vertical magnetic field were acquired at Global Positioning System (GPS)-referenced times and were used as remote references for each other. The high-frequency data were recorded as non-remote referenced single stations.

Table 1 lists the locations of the 51 MT stations. A Garmin E-Trex GPS was used to record the locations during each site setup. Coordinates are referenced to the 1866 Clarke spheroid and North American 1983 Western United States datum. Longitude and latitude format is degrees, minutes, seconds. Universal Transverse Mercator (UTM) Zone 11 North units are in meters. Station elevation is given in meters (NGVD29). The displayed accuracy of the $x, y, z$ component is $\pm 2-5 \mathrm{~m}$. The last column of table 1 lists the remotely referenced MT site for each station.

\section{Magnetotelluric Data}

The recorded time-series data were transformed to the frequency domain and processed to determine a 2-D apparent resistivity and phase tensor at each site. Time-series data sets were selected for optimal signal-to-noise characteristics prior to the cross-power calculations. Cross-power files were created with Egbert's (1997) multiple-station, remote-reference magnetotelluric data-processing algorithms. The MT stations were grouped into seven sounding profiles (fig. 2) based on acquisition and processing preferences. During the analysis and interpretation process, each station was rotated to a fixed angle determined by the given nominal profile orientation. Rotation of the impedance tensor allows for decoupling into the TE and TM modes. Table 2 lists the nominal line azimuths and the fixed, orthogonal angles of rotation for each profile. Low-frequency time-series data were edited with ACQ24, EMI's MT data analysis program to remove noisy data points. 
Table 1. Magnetotelluric station locations. Latitudes and longitudes in WGS 84 and UTM 11N in NAD83 meters. Elevations in NGVD29 (meters). Last column are remote reference MT station pairs.

\begin{tabular}{|c|c|c|c|c|c|c|}
\hline Stations & Latitude & Longitude & Elevation & UTM 11N North & UTM 11N East & Remote \\
\hline 1 & $36,53,51.5$ & $116,11^{\prime} 50.3$ & 1456 & 4083613 & 571518 & 34 \\
\hline 2 & $36,54^{\prime} 37.5$ & $116,10 ’ 21.7$ & 1373 & 4085052 & 573699 & None \\
\hline 3 & $36,54^{\prime} 23.0$ & $116,08^{\prime} 57.9$ & 1304 & 4084623 & 575799 & None \\
\hline 4 & $36,54^{\prime} 04.6$ & $116,07^{\prime} 37.5$ & 1254 & 4084071 & 577772 & 16 \\
\hline 5 & $36,53 ’ 27.0$ & $116,03^{\prime} 46.3$ & 1149 & 4082968 & 583504 & None \\
\hline 6 & $36,53 ’ 36.9$ & $116,02 ’ 23.8$ & 1101 & 4083296 & 585543 & 36 \\
\hline 7 & $36,53,52.5$ & $116,00^{\prime} 47.0$ & 1100 & 4083795 & 587935 & 30 \\
\hline 8 & $36,54^{\prime} 18.2$ & $115,59^{\prime} 08.6$ & 1229 & 4084622 & 590362 & None \\
\hline 9 & $36,57^{\prime} 36.4$ & $116,12^{\prime} 18.9$ & 1536 & 4090540 & 570753 & 46 \\
\hline 10 & $36,58^{\prime} 01.6$ & $116,11^{\prime} 05.3$ & 1437 & 4091331 & 572566 & 47 \\
\hline 11 & $36,58^{\prime} 44.4$ & $116,09^{\prime} 53.3$ & 1445 & 4092663 & 574335 & 50 \\
\hline 12 & $36,59^{\prime} 36.6$ & $116,08^{\prime} 07.0$ & 1463 & 4094297 & 576949 & 49 \\
\hline 13 & $36,599^{\prime} 25.0$ & $116,06^{\prime} 52.1$ & 1335 & 4093950 & 578802 & 48 \\
\hline 14 & $36,59^{\prime} 27.5$ & $116,05^{\prime} 36.6$ & 1243 & 4094053 & 580670 & $48 \mathrm{a}$ \\
\hline 15 & $36,57^{\prime} 34.8$ & $116,04^{\prime} 48.9$ & 1299 & 4090592 & 581884 & 51 \\
\hline 16 & $36,57^{\prime} 38.3$ & $116,04^{\prime} 02.2$ & 1236 & 4090710 & 583035 & 4 \\
\hline 17 & $36,57^{\prime} 26.7$ & $116,02 ’ 16.2$ & 1182 & 4090375 & 585659 & 29 \\
\hline 18 & $36,57^{\prime} 26.5$ & $116,00 ’ 34.3$ & 1186 & 4090400 & 588182 & None \\
\hline 19 & $36,57^{\prime} 22.4$ & $115,59^{\prime} 29.2$ & 1199 & 4090289 & 589792 & 35 \\
\hline 20 & $37,04^{\prime} 01.5$ & $116,12^{\prime} 12.2$ & 1528 & 4102410 & 570816 & 45 \\
\hline 21 & $37,03 ’ 20.9$ & $116,11 ' 12.8$ & 1490 & 4101166 & 572297 & 44 \\
\hline 22 & $37,04^{\prime} 02.3$ & 116,10’01.1 & 1438 & 4102458 & 574055 & 43 \\
\hline 23 & $37,03 ’ 23.6$ & $116,08^{\prime} 16.2$ & 1347 & 4101290 & 576659 & 37 \\
\hline 24 & $37,03^{\prime} 06.3$ & $116,06^{\prime} 52.0$ & 1306 & 4100781 & 578746 & 38 \\
\hline 25 & $37,02^{\prime} 54.4$ & $116,05^{\prime} 09.4$ & 1261 & 4100434 & 581280 & 39 \\
\hline 26 & $37,02 ' 14.0$ & $116,04^{\prime} 05.3$ & 1240 & 4099202 & 582876 & 40 \\
\hline 27 & $37,01^{\prime} 07.0$ & $116,02^{\prime} 00.7$ & 1209 & 4097167 & 585977 & 41 \\
\hline 28 & $37,01^{\prime} 06.3$ & $115,59^{\prime} 45.8$ & 1210 & 4097185 & 589311 & 42 \\
\hline 29 & $37,05^{\prime} 38.3$ & $116,09^{\prime} 55.2$ & 1501 & 4105419 & 574177 & 17 \\
\hline 30 & $37,04,54.5$ & $116,08 ' 10.0$ & 1367 & 4104092 & 576786 & 7 \\
\hline 31 & $37,05^{\prime} 42.2$ & $116,06^{\prime} 51.2$ & 1334 & 4105583 & 578716 & None \\
\hline 32 & $37,05^{\prime} 41.0$ & $116,04 ’ 57.9$ & 1270 & 4105571 & 581515 & None \\
\hline 33 & $37,04^{\prime} 56.9$ & $116,02^{\prime} 58.0$ & 1240 & 4104238 & 584489 & None \\
\hline 34 & $37,04^{\prime} 07.5$ & 116,01 '20.1 & 1241 & 4102745 & 586922 & 1 \\
\hline 35 & $37,04^{\prime} 04.8$ & $115,59 ’ 59.5$ & 1265 & 4102681 & 588914 & 19 \\
\hline 36 & $37,04^{\prime} 19.6$ & $115,58^{\prime} 36.3$ & 1327 & 4103157 & 590961 & 6 \\
\hline 37 & $37,08^{\prime} 26.4$ & $116,08^{\prime} 34.4$ & 1489 & 4110620 & 576125 & 23 \\
\hline 38 & $37,08^{\prime} 16.7$ & $116,06 ’ 16.5$ & 1331 & 4110353 & 579528 & 24 \\
\hline 39 & $37,07^{\prime} 46.8$ & $116,04 ’ 18.5$ & 1292 & 4109457 & 582448 & 25 \\
\hline 40 & $37,07^{\prime} 23.2$ & $116,02 ’ 24.8$ & 1275 & 4108755 & 585262 & 26 \\
\hline 41 & $37,07^{\prime} 06.8$ & $116,01 ' 19.1$ & 1317 & 4108275 & 586891 & 27 \\
\hline 42 & $37,06^{\prime} 45.2$ & $115,59^{\prime} 55.7$ & 1373 & 4107623 & 588955 & 28 \\
\hline 43 & $37,10^{\prime} 03.5$ & $116,088^{\prime} 33.9$ & 1531 & 4113609 & 576110 & 22 \\
\hline 44 & $37,10^{\prime} 07.6$ & $116,08^{\prime} 00.0$ & 1486 & 4113742 & 576943 & 21 \\
\hline 45 & $37,13 ’ 13.1$ & $116,08^{\prime} 41.3$ & 1612 & 4119451 & 575875 & 20 \\
\hline 46 & $37,12 ’ 25.4$ & $116,07^{\prime} 13.2$ & 1564 & 4118000 & 578059 & 9 \\
\hline 47 & $37,13 ’ 35.5$ & $116,04 ' 19.3$ & 1575 & 4120201 & 582325 & 10 \\
\hline 48 & $37,13,50.6$ & 116,03 '39.5 & 1560 & 4120677 & 583300 & 13 \\
\hline 49 & $37,13,54.7$ & $116,02 ’ 25.7$ & 1486 & 4120819 & 585119 & 12 \\
\hline 50 & $37,13^{\prime} 12.2$ & $116,03 ’ 52.7$ & 1536 & 4119490 & 582990 & 11 \\
\hline 51 & $37,11 ' 50.5$ & $116,02 ’ 44.8$ & 1356 & 4116992 & 584688 & 15 \\
\hline
\end{tabular}




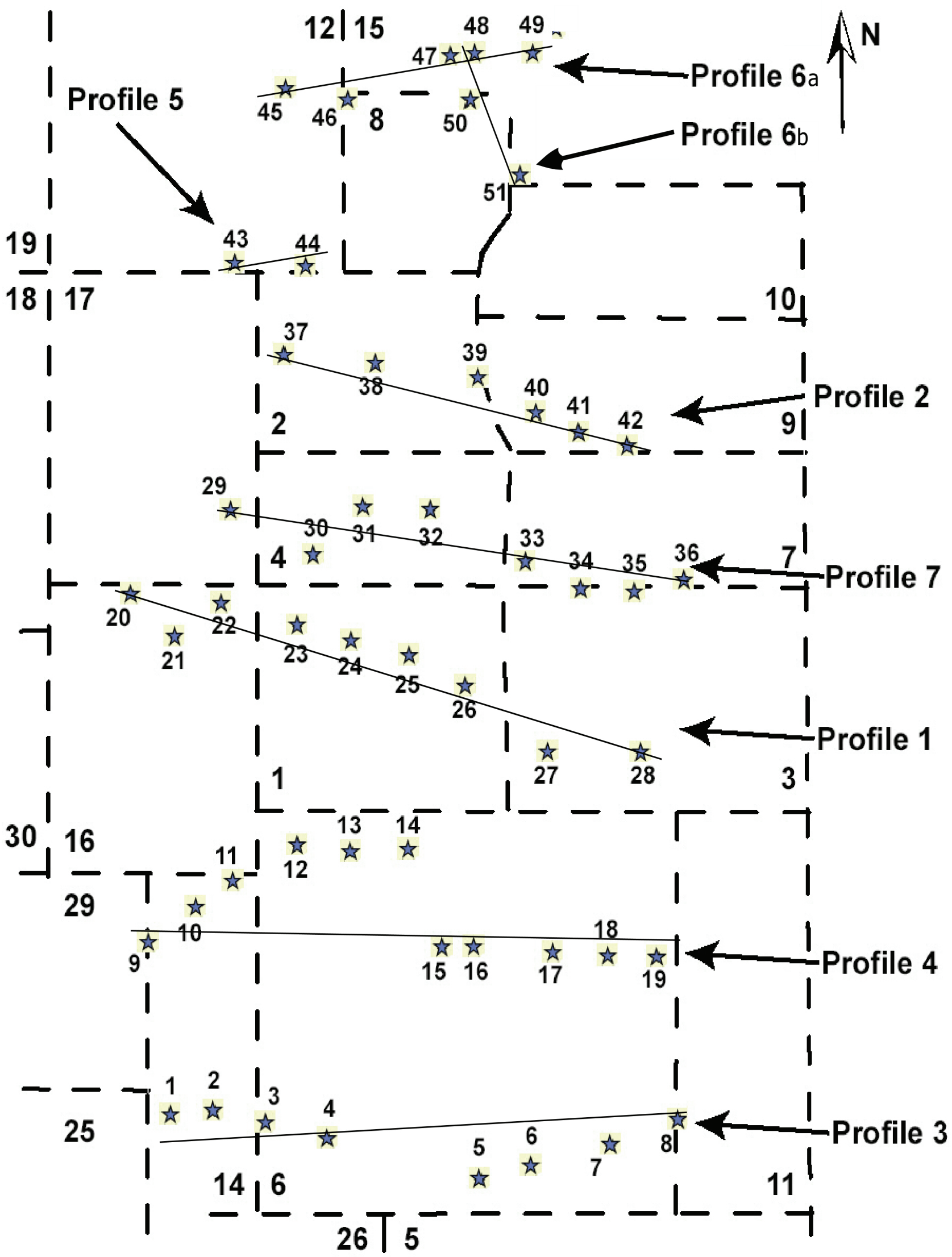

Figure 2. Schematic image showing magnetotelluric (MT) stations in and near Yucca Flat, Nevada Test Site, Nevada, grouped into eight profiles. Approximate azimuth of each profile indicated by solid black lines. MT stations acquired in 2003 are numbered 1-51 (stars). Dashed lines are boundaries of Nevada Test Site Areas 1-7, 9-12, 14-19, 25, 26, 29, and 30. 
Table 2. MT profile azimuths and angles of rotation applied during processing.

\begin{tabular}{|c|c|c|c|}
\hline $\begin{array}{c}\text { Profile } \\
\text { Number }\end{array}$ & $\begin{array}{c}\text { MT Stations in } \\
\text { Profile }\end{array}$ & $\begin{array}{c}\text { Profile } \\
\text { Azimuth } \\
\text { (Degrees) }\end{array}$ & $\begin{array}{c}\text { Fixed Angle } \\
\text { of Rotation } \\
\text { (Degrees) }\end{array}$ \\
\hline 1 & $20-28$ & 106 & 16 \\
\hline 2 & $37-42$ & 103 & 13 \\
\hline 3 & $1-8$ & 87 & -3 \\
\hline 4 & $9-19$ & 91 & 1 \\
\hline 5 & $43-44$ & 81 & -9 \\
\hline $6 \mathrm{a}$ & $45-49$ & 81 & -9 \\
\hline $6 \mathrm{~b}$ & $48-51$ & 146 & 56 \\
\hline 7 & $29-36$ & 98 & 8 \\
\hline
\end{tabular}

The effects of near-surface resistivity anomalies can cause what are known as "static shifts" in the data (Sternberg and others, 1988). Cultural features also can affect the measured magnetotelluric responses. These include fences, pipelines, communication lines, railways, and other manmade conductors. There were significant static shifts at stations 4 , 20, 22, 23, 39, 46, 47, 48, and 50 .

As mentioned above, the raw, field-processed MT data are presented in USGS Open File Reports (Williams and others, 2005a, 2005b, 2005c, 2005d, 2005e, and 2005f). These reports include the following plots for each station: apparent resistivity, impedance phase, rotation angle, impedance skew, multiple coherency, impedance polar plots, tipper magnitude, tipper strike, and HzHx and HzHy coherency. Error bars (],[) on the apparent resistivity, impedance phase, skew, tipper magnitude, and tipper strike plots represent probable errors within one standard deviation of the sample variance (Gamble and others, 1979).

Apparent resistivity is the approximate ratio of the electric-field strength to the magnetic-field strength at a given frequency. The impedance phase is proportional to the slope of the apparent resistivity curve on a log-log plot, but using baselines at \pm 45 degrees (Vozoff, 1991). A measure of the dimensionality for MT data is provided by the impedance skew of the impedance tensor (Vozoff, 1972). If the effective measured resistivity response to the geology beneath a MT station truly is one or two dimensional, then the skew will be zero. Instrument and environmental sources of electrical noise can cause non-zero skew values. Skew values typically are small (about 0.1 ) for relatively low-noise recordings. Higher skews (above 0.2) are an indication of either the resistivity response to 3-D geology or higher levels of noise. Manmade electrical noise, such as power lines, power generators, and moving vehicles and trains, can have a negative effect on MT data quality. All of these local disturbances can produce incoherent noise that mainly affects frequencies above 1 Hz. Other manmade electrical noise, such as direct-current electric trains and active cathodic protection of pipelines, produces coherent electromagnetic signals that mainly affect frequencies below $1 \mathrm{~Hz}$.
In the survey area, noise from a number of small power lines and small moving vehicles was negligible at distances greater than $0.4 \mathrm{~km}$ from the noise source. Power-line signal levels were measured at each site and typically were less than 20 percent of the maximum recordable signals. Noise from larger power lines, power generators, pipelines, and trains was negligible at distances greater than $5 \mathrm{~km}$. Local lightning, wind, and rainstorms also can degrade data quality. Burying the magnetic induction coils and the electric dipole wires minimized wind noise.

Predicted values of the electric field can be computed from the measured values of the magnetic field (Vozoff, 1991). The coherence of the predicted electric field with the measured electric field is a measure of the signal-to-noise ratio provided in the multiple coherency plots. Values are normalized between 0 and 1 ; values at 0.5 signify signal levels equal to noise levels. For this data set, coherencies generally were at an acceptable level, except at times in the frequency ranges of 0.01 to $5 \mathrm{~Hz}$ (often referred to as the "dead band").

The field-processed MT data include some scatter and poor signal-to-noise ratios. Spectral results were inspected visually for noisy data, and the best signal-to-noise field data were combined into the final plots and spectral data sets.

The magnetotelluric impedance polar plots (Williams and others, 2005a, 2005b, 2005c, 2005d, 2005e, and 2005f) provide a measure of MT data dimensionality (Reddy and others, 1977). For 1-D resistivity structures, the principal impedance polar diagram (dashed line) is a circle. For 2-D or 3-D resistivity structures, the principal impedance polar diagram elongates either parallel or perpendicular to strike direction. Over resistors, the principal impedance polar diagram elongates perpendicular to strike direction, and over conductors it elongates parallel to strike direction. For 2-D resistivity structures, the additional impedance polar diagram attains the shape of a symmetric cloverleaf. For 3-D resistivity structures, the additional impedance polar diagram (solid line) elongates in one direction, and its amplitude is comparable to that of the principal impedance polar diagram (dashed line).

The magnetotelluric "tipper" is calculated from the vertical component of the magnetic field. The tipper magnitude is a measure of the "tipping" of the magnetic field out of the horizontal plane (Vozoff, 1991). It will be equal to zero for the 1 -D case. Typically the tipper value is between 0.1 to 0.5 and seldom approaches 1 . The tipper responds primarily to vertical and subvertical structures. The tipper magnitude of the stations discussed in this report ranged from 0.1 to 0.6 over the lower frequencies. This indicates some lateral contacts or vertical structure at depth. The tipper strike is used to help resolve the 90-degree ambiguity in the impedance rotation angle. The $\mathrm{HzHx}$ and HzHy coherency is a measure of the signal-to-noise ratio of the vertical magnetic field with respect to each of the orthogonal, horizontal magnetic field components. Values are normalized between 0 and 1 ; values at 0.5 signify signal levels equal to noise levels. These three-component magnetic-field coherencies provide a check on the signal-to-noise ratio of the measured values in the tipper magnitude and tipper strike plots. 


\section{Two-dimensional Resistivity Modeling}

A 2-D modeling analysis of the Yucca Flat MT data has been performed. Wannamaker (1983) found that while some MT responses in the Basin and Range region are fundamentally 3-D in nature, for elongated structures, 2-D modeling could be used to construct reasonable estimates of the resistivity cross-sections along each profile. Wannamaker and others (1984) demonstrated that approximating 3-D structure beneath a centrally located profile with 2-D modeling is best achieved when fitting the TM curve even at the expense of a poor fit of the TE curve. However, because TM data are relatively insensitive to the depth extent of a subsurface body (Eberhart-Phillips and others, 1995), the depths to the base of the bodies in the model are not well constrained. Hence, clarifying the model limits with 3-D resistivity modeling may be necessary.

Two-dimensional resistivity models were constructed for each profile by first conducting a 2-D inversion of the TM data using the computer program, RLM2DI (Mackie and others, 1997; Rodi and Mackie, 2001). This was followed by the application of many iterations of the 2-D forward modeling algorithm program, PW2D, developed by Wannamaker and others (1987). The results of the RLM2DI 2-D inversion were used as the initial input model for the forward modeling, PW2D, where a sensitivity analysis was performed on the conductive structures derived from the inversion results.

RLM2DI uses a finite-difference network analog to the Maxwell's equations governing magnetotellurics to calculate the forward solution, and a non-linear conjugate gradient optimization approach that is applied directly to the minimization of the objective function for the inverse problem. PW2D is a stable finite-element algorithm that simulates transverse electric and magnetic fields using a linear basis across each finite element. The inversion algorithm, RLM2DI, was usually allowed to batch run for 25 iterations in order to reduce the root mean squared (RMS) error to a reasonable value between the field data and the numerical model. The number of iterations of forward modeling (PW2D) necessary depended on how complex the profile inversion results were from RLM2DI.

Table 3 lists the number of horizontal and vertical nodes that were used in the modeling for each profile. The variability in the number of nodes from profile to profile is due to the different number of MT stations along each profile. In all cases the number of horizontal and vertical nodes necessary for the iterative forward modeling (PW2D) algorithm to accurately model the resistivity distribution in the Yucca Flat subsurface is greater than the number of nodes required by the inversion algorithm (RLM2DI). This is a function of some fundamental differences between how finite-difference and finite-element algorithms handle the numerical boundary conditions and, subsequently, how the electric and magnetic fields are calculated across the mesh.
Table 3. Inversion (RLM2DI) and forward (PW2D) numerical model meshes for each profile. The number of horizontal ("Horiz") nodes and vertical ("Vert") nodes in each model mesh are listed. Nine additional vertical nodes were used to model the overlying air layer.

\begin{tabular}{|c|c|c|c|c|}
\hline Profile & \multicolumn{2}{|c|}{ RLM2DI } & \multicolumn{2}{c|}{ PW2D } \\
\hline No. & Horiz & Vert & Horiz & Vert \\
\hline 1 & 73 & 58 & 104 & 63 \\
\hline 2 & 66 & 58 & 97 & 62 \\
\hline 3 & 76 & 58 & 93 & 63 \\
\hline 4 & 57 & 58 & 93 & 63 \\
\hline 5 & 66 & 58 & 127 & 76 \\
\hline $6 \mathrm{a}$ & 64 & 58 & 146 & 90 \\
\hline $6 \mathrm{~b}$ & 65 & 58 & 100 & 76 \\
\hline 7 & 62 & 58 & 124 & 90 \\
\hline
\end{tabular}

The edges of the model were extended to over $800 \mathrm{~km}$ horizontally and $450 \mathrm{~km}$ vertically to minimize edge effects. The resolution of the resistivity boundaries used for each model is somewhat subjective. If different resistivities were used, then boundary positions and layer depths would have to be adjusted to achieve similar fits to the observed data. The extreme case would be to use a model with a "continuous" resistivity gradient from low to high resistivities. The resolution of the resistivity boundaries is also, in part, a function of the model grid-mesh design. We have attempted to keep each model simple. The depths of the MT profiles models are relative to the Earth's surface.

\section{Discussion}

Yucca Flat is an elongate alluvial basin that formed consequent to regional crustal extension that was oriented generally east-west (Cole and others, 1997). The basin shows many characteristics typical of the basin-and-range structural province in which it lies. The overall geometry of the basin was largely controlled by down-to-the-east displacements on the general northerly trending Carpetbag fault system and westward tilting of Miocene strata. There are numerous smaller faults in the basin that also have a northerly trend. These structural trends are displayed on plate 1, which is an image of the geology of a portion of the Nevada Test Site developed by Slate and others (1999). The 51 MT data stations acquired in 2003 are indicated on plate 1 by blue x's labeled with a station number.

The Yucca Flat geology depicted on plate 1 is known to be quite complicated in areas where there are drill holes for ground truth and is possibly more complicated than shown in areas without ground truth. However, from the hydrologic point of view, different geologic units can be combined into either aquifer-type groupings or confining unit-type groupings. Figure 3 presents hydrostratigraphic correlations between the geologic units and the hydrologic groupings (Prothro and others, 2004). 


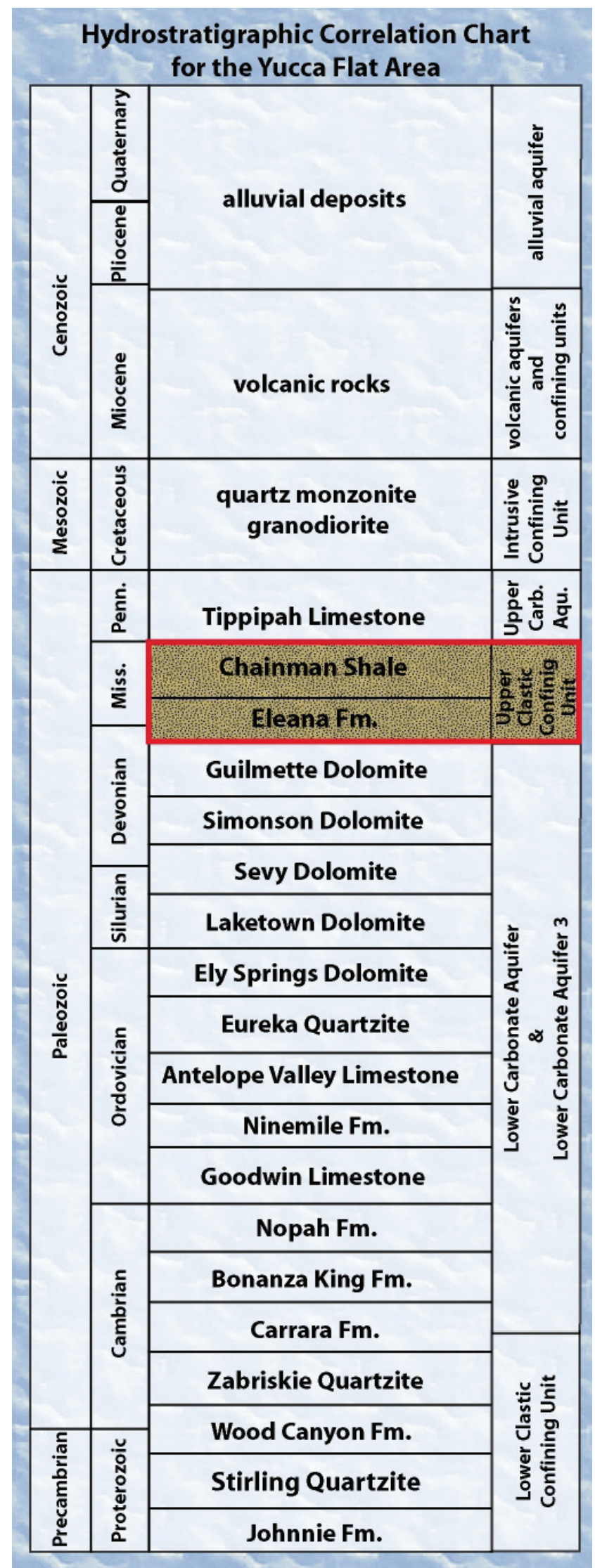

Figure 3. Hydrostratigraphic correlation chart for the Yucca Flat area (from Prothro and others, 2004).
In the MT interpretations presented below, the hydrogeologic groupings are used to label the inferred geologic units. Table 4 lists the abbreviated label names and the corresponding hydrologic grouping.

Table 4. Hydrologic groups and associated abbreviations

\begin{tabular}{|l|l|}
\hline \multicolumn{1}{|c|}{ Hydrogeologic grouping } & Abbreviation \\
\hline Alluvial deposits and aquifer & $\mathrm{A}$ \\
\hline Welded volcanic units & $\mathrm{W}$ \\
\hline Volcanic aquifers and confining rock units & $\mathrm{V}$ \\
\hline Upper carbonate aquifer & UCA \\
\hline Upper clastic confining unit & UCCU \\
\hline $\begin{array}{c}\text { Lower carbonate aquifer and lower carbonate } \\
\text { aquifer } 3\end{array}$ & LCA \\
\hline Lower clastic confining unit & LCCU \\
\hline
\end{tabular}

The 2-D magnetotelluric interpretations of the electrical resistivities and structures under Yucca Flat are presented in this section (fig. 4-21). The interpreted resistivity models for profiles 1-7 generally fit the TM data better than the TE data (see Appendix A), although fits to the TE data were satisfactory for stations where 2-D structure was indicated. However, because of the widespread 3-D character of the survey area as indicated by the modeling results, only the gross structure determined by the models is discussed.

Multiple interpretations are presented for each profile. These are related to the limits on the resolution of the magnetotelluric technique that are due to the physical property contrasts of the host rocks (in particular, electrical conductivity of the rocks) and the depth at which they occur. Properties of thin, conductive geologic units at great depths will not be well determined. A detectability rule of thumb is to use a 10:1 ratio of depth to thickness. For example, at $10 \mathrm{~km}$ depth, a conductive unit $1 \mathrm{~km}$ thick may be detected. If the unit is less than $1 \mathrm{~km}$ thick at $10 \mathrm{~km}$ depth, its detectability is decreased. In particular, in Profiles 1, 2, and 4 discussed below, possible geologic units presented at depths between $5 \mathrm{~km}$ to $10 \mathrm{~km}$ are included only for feasibility and modeling analysis. The geologic relationships may not be consistent with Cole and others (1997) or other known stratigraphic relationships in the Yucca Flat region.

Appendix A contains, for each profile, the final 2-D models (the same as figures 4-21 but with the forward-modeling mesh displayed) and plots of the observed and calculated apparent resistivity and phase curves for each station. The models are organized by profile number (1-7) and subdivided by the model number shown in the upper right corner of the 2-D model figure. The " 1 " in front of the station identifiers in the figures was required by the inversion software and should be ignored. Each model is presented in the following order: First is the 2-D model without the interpretations shown in figures $4-21$, followed by 
figures showing the observed and calculated apparent resistivity sounding curves and, finally, by figures showing the observed and calculated impedance phase curves.

All the MT profile interpretations presented here have general similarities regarding the electrical resistivities of the different hydrogeologic units. Generally, the upper clastic confining unit (UCCU, consisting of Chainman Shale and Eleana Formation) is more electrically conductive (around 10-20 ohm-m) than the lower clastic confining unit (LCCU, consisting of Precambrian and Cambrian units) that has electrical resistivities around $50 \mathrm{ohm}-\mathrm{m}$. The lower carbonate aquifer (LCA, consisting of several Paleozoic units) and the upper carbonate aquifer (UCA, consisting of the Tippipah Limestone) are electrically resistive (around 200-2000 ohm$\mathrm{m})$. The volcanic aquifers and confining units (V) are moderately electrically conductive (20-50 ohm-m), while the alluvial deposits and aquifers (A) are moderately resistive (around 50-100 ohm-m). Marble and intrusive granite units (MGCU, consisting of quartz monzonite granodiorite) along Profile 6 at the northern end of the Yucca Flat basin are also quite resistive (around 500-5000 ohm-m).

\section{Profile 1 - Central Yucca Flat}

Profile 1 crosses the middle of the Yucca Flat basin (see fig. 2) and consists of MT stations 20-28. Three possible 2-D interpretations for Profile 1 are presented in figures 4 through 6. Resistivity model 128 (fig. 4) lithologically shows the resistive (500 ohm-m) UCA overlying the more conductive (10-20 ohm-m) UCCU in possibly a synclinal relationship (consistent with surface geological observations) under stations 20-24 (120-124 in fig. 4). The UCCU, in turn, overlies the more resistive (500-1000 ohm-m) LCA unit that extends below 10 $\mathrm{km}$ depth. The LCA is also present under stations 25 to 28 down to about 6 to $9 \mathrm{~km}$ depth. A moderately conductive zone may extend to depth beneath stations 23 and 24 and thickens and dips eastward, below $5 \mathrm{~km}$, under stations 25 and 26. It is inferred that this deeper conductive zone is the lower clastic confining unit (LCCU). The boundary between the UCCU and the LCCU under stations 23 and 24 is not well defined. The exact nature (thickness, dip) of the LCCU under stations 25 through 28 is also not well determined by the 2-D MT modeling due to the combination of the thickness, depth, and the smaller resistivity contrast of the inferred geologic unit. The inferred LCCU conductive zone as presented in this profile is included to test its feasible existence based on the resulting power of the MT data at these depths. However, its existence is not required by the data. Between stations 26 and 28, alluvial deposits (A) overlie more conductive volcanic rocks (V).

Structurally, there appear to be large faults crossing this profile. Near the surface beneath station 24 and extending to depth beneath stations 25-28 it is inferred that the CP thrust is controlling the distribution of the UCCU and LCCU hydrogeologic units. At depths between about $300 \mathrm{~m}$ and $2 \mathrm{~km}$ it appears that the Topgallant Fault or the Carpetbag Fault and the Yucca Fault are cutting off the volcanic and alluvial units between stations 26 and 27.
A comparison of model 128 and the polar plots in Williams and others (2005a) indicates a 3-D character at stations 20, 21, 25, and 26 (fig. A3). The tipper strike indicates that the electrical resistivity structure is sub-parallel to the profile direction near stations 22-24 and 27-28. The 3-D structure begins to affect stations 20 and 21 at about $1-2 \mathrm{~km}$ away (in distance or depth or both). At stations 25-26 the structure is 3-D beyond or below $10 \mathrm{~km}$ depth. By definition, the TE mode is perpendicular to the profile direction and parallel to the electrical resistivity structure. For cases such as at stations 22-24 and 27-28, the TE mode is invalid, and so only the TM mode should be fit (fig. A3).

Profile 1 model numbers 129 (fig. 5) and 130 (fig. 6) are slight variations of model 128 . These models provided some insight into variable thicknesses, electrical conductivities, and boundaries of the different units. The permissible lateral variation of the vertical boundary between the conductive UCCU/ LCCU and the resistive LCA near station 24 in the upper 5 $\mathrm{km}$ depth is shown in figure 5. The computed misfits (fig. A6) allowed moving the LCA resistive vertical boundary near but not directly beneath station 23 . The computed misfits also did not allow moving the LCA/LCCU boundary east of station 24 .

The minimum UCCU thickness in the upper $5 \mathrm{~km}$ under stations 20-23 is shown by the 10-50 ohm-m conductor in model 128 (fig. 4). The maximum UCCU thickness under stations 20-23 is shown in model 130 (fig. 6) where the 10-50 ohm-m conductor has been slightly thickened. The minimum depth to the LCCU below $5 \mathrm{~km}$ depth under stations 24-28 is the eastward-dipping $50 \mathrm{ohm}-\mathrm{m}$ conductor shown in figure 4. A LCCU thickness less than $1 \mathrm{~km}$ is also permissible below the depths shown. However, as mentioned above, resolution of a thin conductor at depth is limited.

\section{Profile 2 - Northern Yucca Flat}

Profile 2 crosses the northern end of the Yucca Flat basin (fig. 2) and consists of stations 37-42. Two slightly different, but equally permissible, geologic interpretations are presented in figures 7 and 8 for Profile 2. As discussed in Profile 1 above, the existence of the moderately conductive inferred LCCU is not required by the MT data, but is included only to test its feasible existence based on the resolving power of the acquired MT data. The difference is the range of interpreted thicknesses of the conductive UCCU and LCCU units. In model 48 (fig. 7) the UCCU is approximately $3 \mathrm{~km}$ thick, and in model 51 (fig. 8) it is only about $500 \mathrm{~m}$ thick. There is no significant difference in the computed apparent resistivity misfits for the two models (fig. A12 for model 48; fig. A15 for model 51). Note that approximately $400 \mathrm{~m}$ of similarly conductive alluvium and volcanics are interpreted to be directly on top of the UCCU under station 37 based on nearby drill holes U2ca, U2ce, and UE2ce, which are east of station 37. The lower boundary of the UCCU is also not well determined. Figures 7 and 8 also show the minimum depth to the LCCU beneath stations $39-42$ below $5 \mathrm{~km}$ depth. 


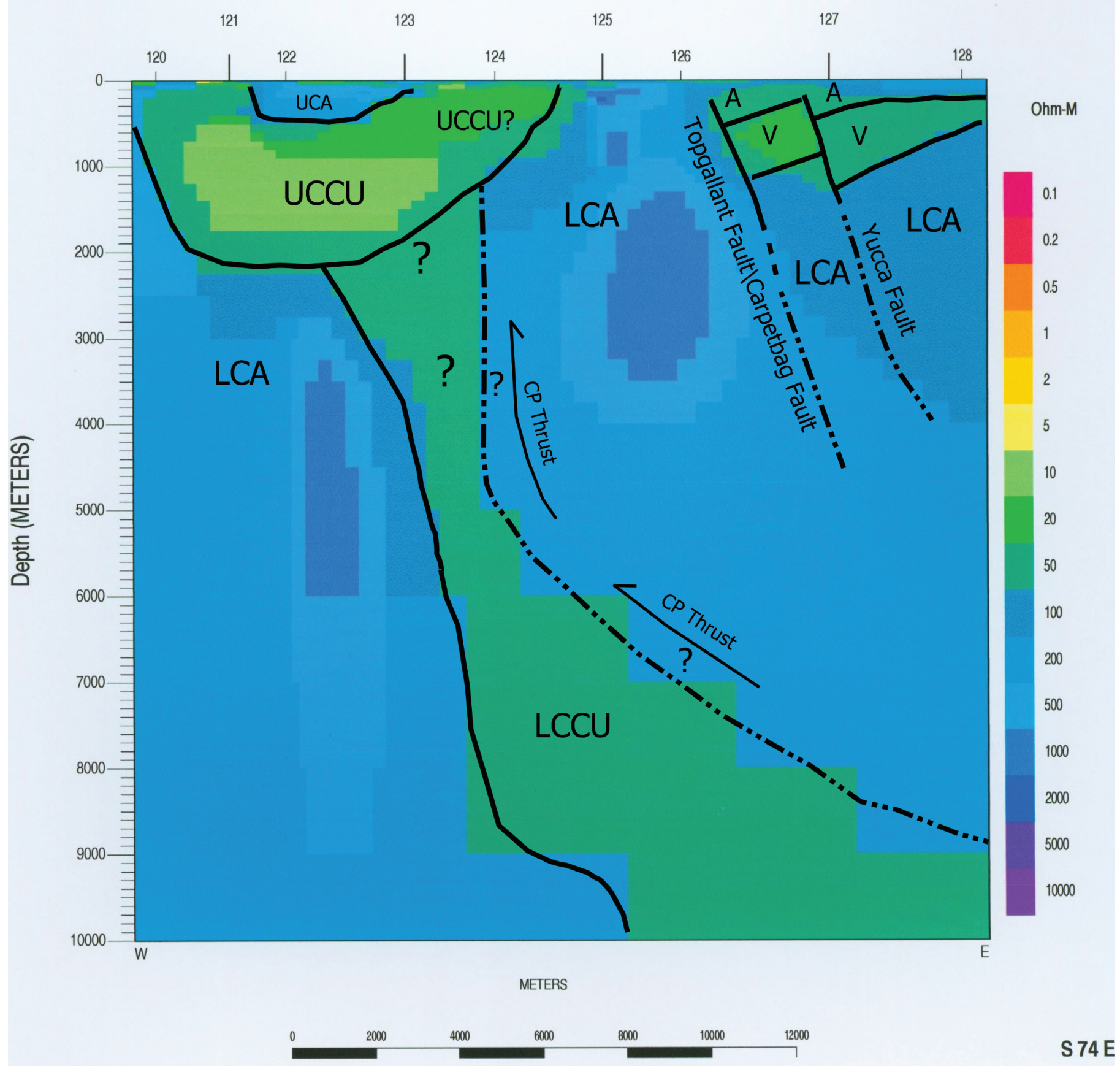

Figure 4. 2-D modeling results for Profile 1. Model 128. Refer to table 4 for key to geologic unit abbreviations. 


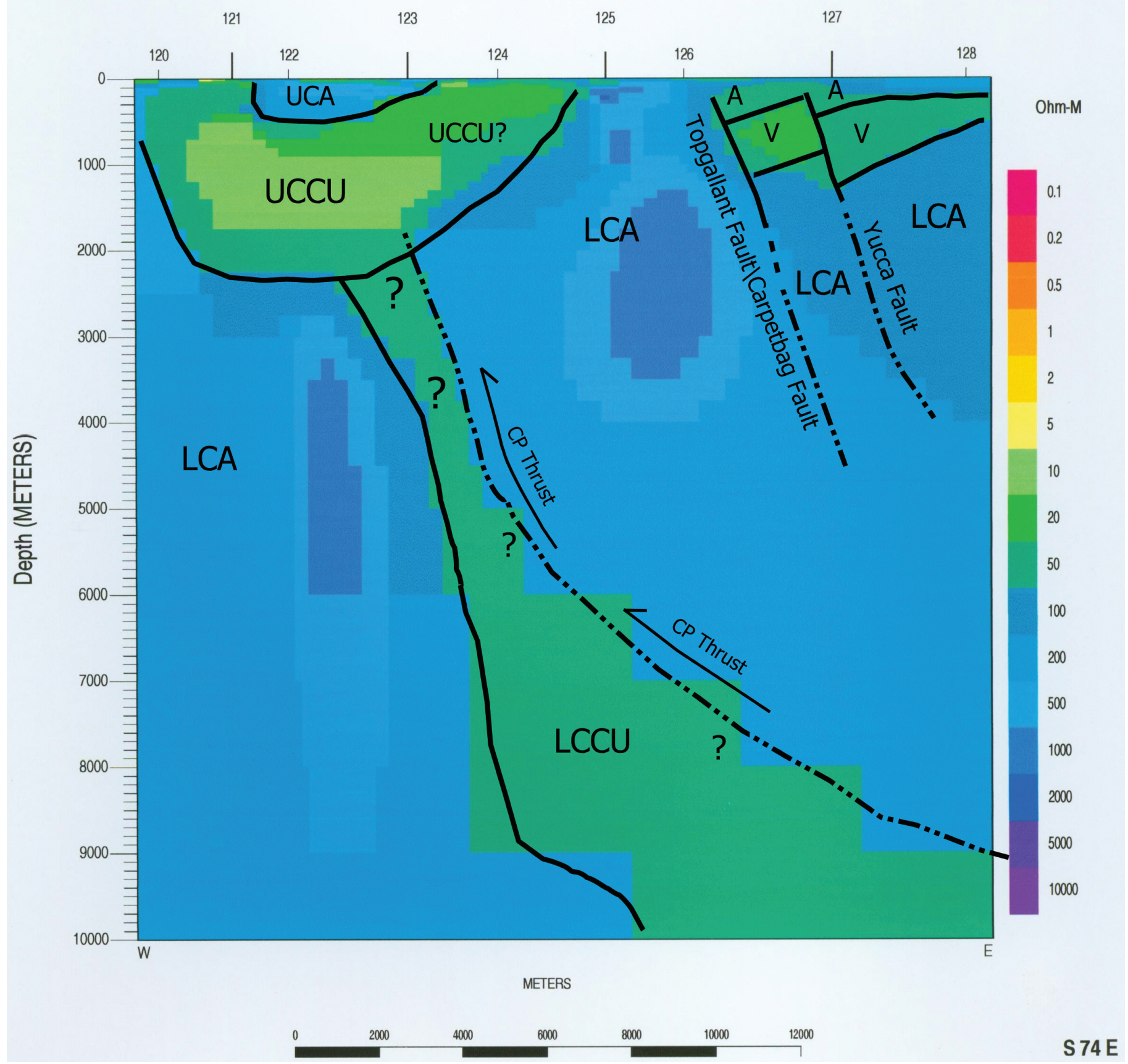

Figure 5. 2-D modeling results for Profile 1. Model 129. Refer to table 4 for key to geologic unit abbreviations. 


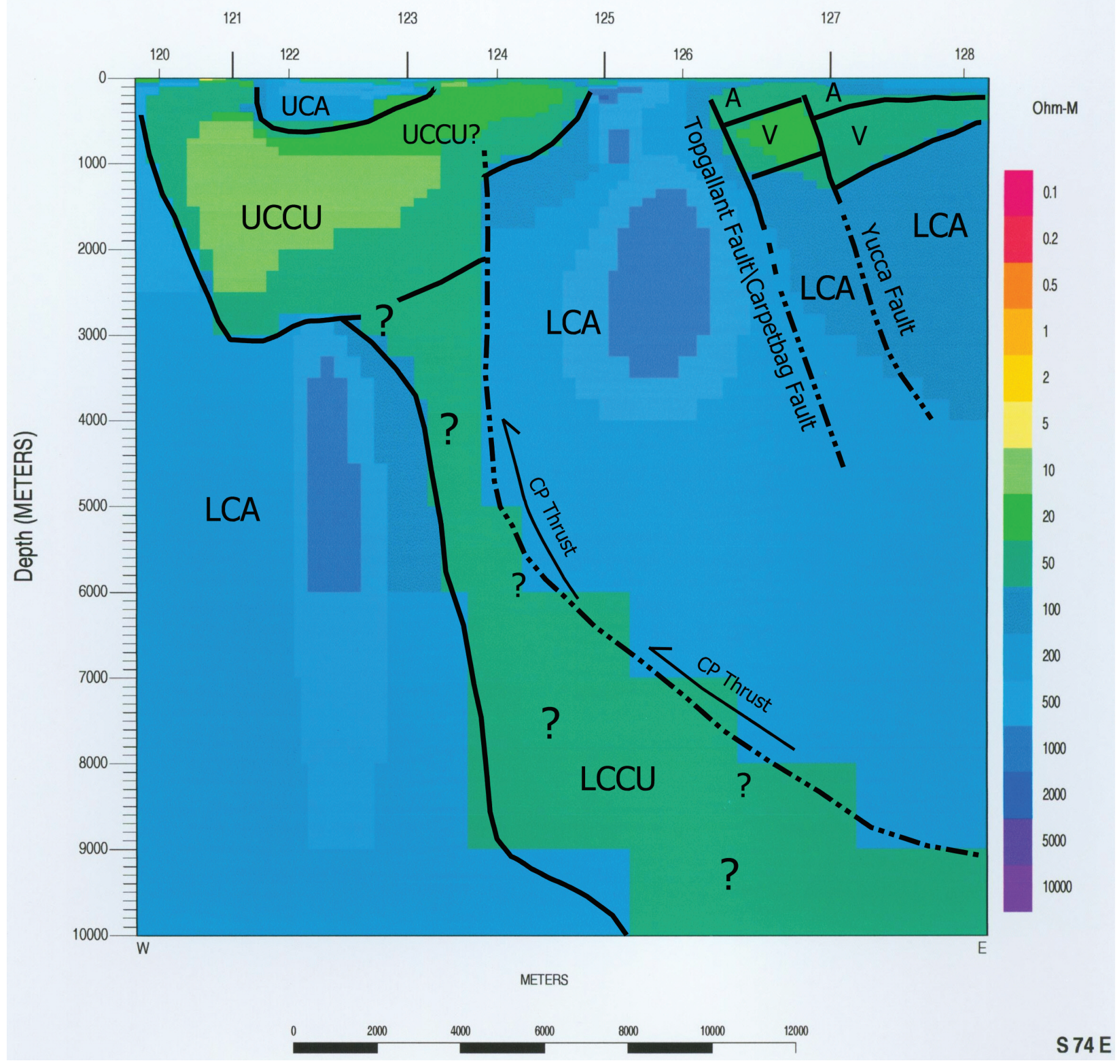

Figure 6. 2-D modeling results for Profile 1. Model 130. Refer to table 4 for key to geologic unit abbreviations. 
The LCA appears to overlay the UCCU under station 38 and may be near station 37 in models 48 and 51. In the upper $5 \mathrm{~km}$ depth, the computed misfits (figures A12, A15) allowed moving the western LCA boundary near but not directly beneath station 37 as shown in figures 7 and 8 . The computed misfits did not allow moving the western LCA boundary east of station 38 .

There is a very conductive, shallow zone ( $5 \mathrm{ohm}-\mathrm{m})$ between stations 41 and 42 that is required by the data. In figure A12 note the sharp decrease in resistivity at station 42 as compared to station 41 above $100 \mathrm{~Hz}$. Near stations 39-42 the volcanic unit can be represented by a $50 \mathrm{ohm}-\mathrm{m}$ resistivity distribution whose boundaries approximate those derived from nearby shallow wells U2r-1, U2z-1, U9d, U9co, U9aw, U9bi-1, U9bi-2, UE9cp, U9cm, and UE9cn. However, the resistivity for the shallow alluvium appears to vary from 20-100 ohm-m making it more difficult to distinguish it from the deeper volcanic material.

Structurally, the CP thrust fault appears to approach the surface just east of station 37 . The geologic image in plate 1 suggests that the fault may also be present just east of station 38. The Carpetbag fault, which, in plate 1, is part of a complicated fault zone, is suggested just west of station 39. The modeling results suggest a fault just west of station 40 . The geologic image suggests that this fault is likely the northerlytrending Yucca fault.

A comparison of model 48 and polar plots in Williams and others (2005b) indicates that the geology under station 39 is 3-D in the shallow alluvium and beyond or below 14 $\mathrm{km}$ depth or both at station 42 . The tipper strike indicates that the resistivity structure is sub-parallel to the profile beyond or below $17 \mathrm{~km}$ at station 37 . Elsewhere under the stations along the profile the geology is approximately 2-D.

\section{Profile 3 - Northern Frenchman Flat}

Profile 3 is south of Yucca Basin and just begins to cross the northern end of Frenchman Flat near French Peak. Profile 3 includes MT stations 1-8. Two models, 92 and 93 (figures 9 and 10), are presented for Profile 3. The difference between the models is a minimum/maximum variation in the nature and thickness of the inferred UCCU under stations 6-8. In model 92 (fig. 9) the UCCU is more conductive (10-50 ohm-m) and also thinner (about $2 \mathrm{~km}$ thick) than in model 93 (fig. 10), where the resistivity of the UCCU is approximately $20 \mathrm{ohm}-\mathrm{m}$ and about $3 \mathrm{~km}$ thick. Except for the 2-D response from $0.1 \mathrm{~Hz}$ to $1 \mathrm{~Hz}$ at station 7 where the computed TE data better fits the observed TE data, there is no significant difference in the computed apparent resistivity misfits for the two models (fig. A18 for model 92; fig. A21 for model 93).

The computed misfits for these models (figures A18 and A21) between stations 4 and 5 did not allow any of the following test cases: a 100-m UCCU thickness in the upper $1 \mathrm{~km}$, a 200-m thick UCCU in the upper $2 \mathrm{~km}$, nor a 250-m thick UCCU in the upper 3 $\mathrm{km}$ of the section. Thinner UCCU thicknesses may be permissible but cannot be resolved with the MT data along this profile.

The maximum permissible western boundary for the 20-50 ohm-m conductor in the upper $5 \mathrm{~km}$ between stations 6 and 7 is adjacent to and east of station 6 using the minimum UCCU thickness model (model 92, fig. 9) and $300 \mathrm{~m}$ further to the east using the maximum UCCU thickness model (model 93, fig. 10). The computed data fit the observed data better for model 92 .

Under stations 1-3 and 5-7, shallow, resistive (100-200 ohm-m), welded volcanic tuffs, known from nearby wells UE-5j, WW-4A, and WW-4, are interpreted to overlay more conductive (10-50 ohm-m) zeolitic volcanic tuffs. Under stations 5-7 the MT modeling was not able to resolve the interpreted boundary between the welded and zeolitic volcanics in the upper $1 \mathrm{~km}$ without assuming 50-100 ohm-m for the zeolitic volcanics and $200 \mathrm{ohm}-\mathrm{m}$ for the welded volcanics. The interpreted boundary under these stations was not permissible using only $50 \mathrm{ohm}-\mathrm{m}$ for the zeolitic volcanics and 100-200 ohm-m or just 200 ohm-m for the welded volcanics.

Structural fault controls appear to have a strong influence on the eastern end of the line. Several faults appear to cross through the section near stations 3 and 4 and between stations 5-8. The geologic image in plate 1 indicates different faults passing through this area or even intersecting in some unknown fashion.

A comparison of model 92 and polar plots in Williams and others (2005c) indicates that the geology near station 2 becomes 3-D at about $10 \mathrm{~km}$ away in distance or depth or both as does the geology near station 7 beyond or below about $15 \mathrm{~km}$ depth. The geology near station 8 becomes 3-D beyond or below about $4-5 \mathrm{~km}$. The tipper strike indicates that the resistivity structure is sub-parallel to the profile beyond or below about $1 \mathrm{~km}$ at stations 1 and 3 and in the shallow alluvium at station 4 . The resistivity structure is sub-parallel to the profile to over $10 \mathrm{~km}$ at stations 5 and 6 .

\section{Profile 4 - Southern Yucca Flat}

Profile 4 begins with station 9 in Mid-Valley, proceeds eastward across Mine Mountain and into Yucca Basin, and ends just east of Yucca Lake at station 19. Two models, 53 and 60, are presented (figures 11 and 12) as interpretations of the geology along Profile 4. Again, the differences between the two models show the minimum and maximum thickness of what is inferred to be the UCCU under stations 10, 11, 15, and 16. As discussed above, these models are possible representations of the subsurface geology. While the MT data support these representations, detailed resolution of structures at depth is limited. Model 53 (fig. 11) depicts a thin UCCU (approximately 500 $\mathrm{m})$ beneath stations 10 and 11 that doesn't extend westward to station 9 and an even thinner UCCU (300 m) under stations 15 and 16. The maximum thickness of the UCCU that the modeling still permits is presented in model 60 (fig. 12). Here, the UCCU under stations 10 and 11 is approximately $2 \mathrm{~km}$ thick between $1500 \mathrm{~m}$ and $3800 \mathrm{~m}$ depth and extends westwards toward station 9 where its termination is possibly fault controlled. The maximum thickness of the UCCU under stations 15 and 16 is depicted in model 60 (fig. 12) and is approximately $1500 \mathrm{~m}$ thick. Note the shallow, thin wedge of UCCU under station 12 on the eastern slope of Mine Mountain. 

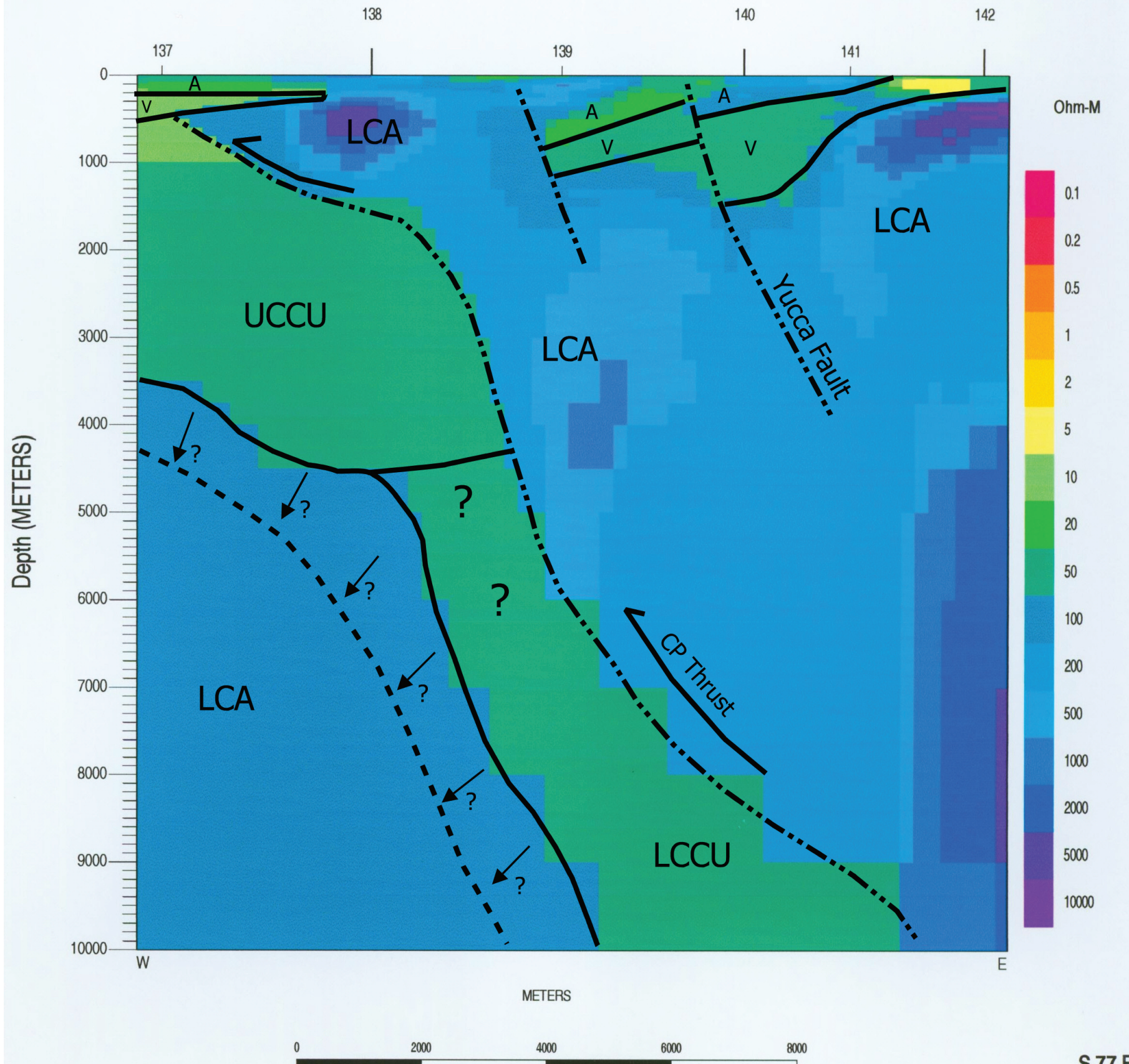

4000

6000 8000

Figure 7. 2-D modeling results for Profile 2. Model 48. Refer to table 4 for key to geologic unit abbreviations. 


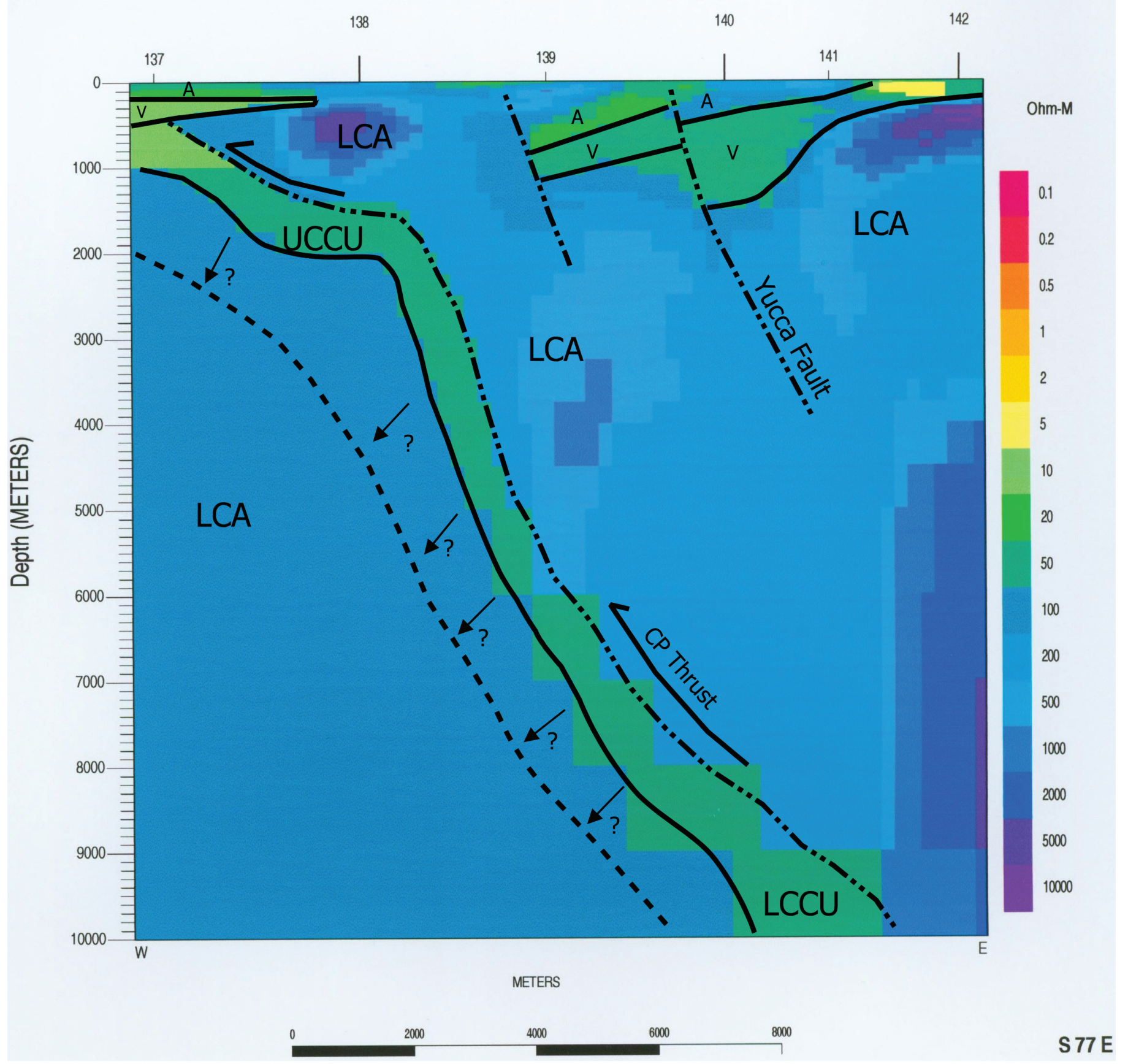

Figure 8. 2-D modeling results for Profile 2. Model 51. Refer to table 4 for key to geologic unit abbreviations. 


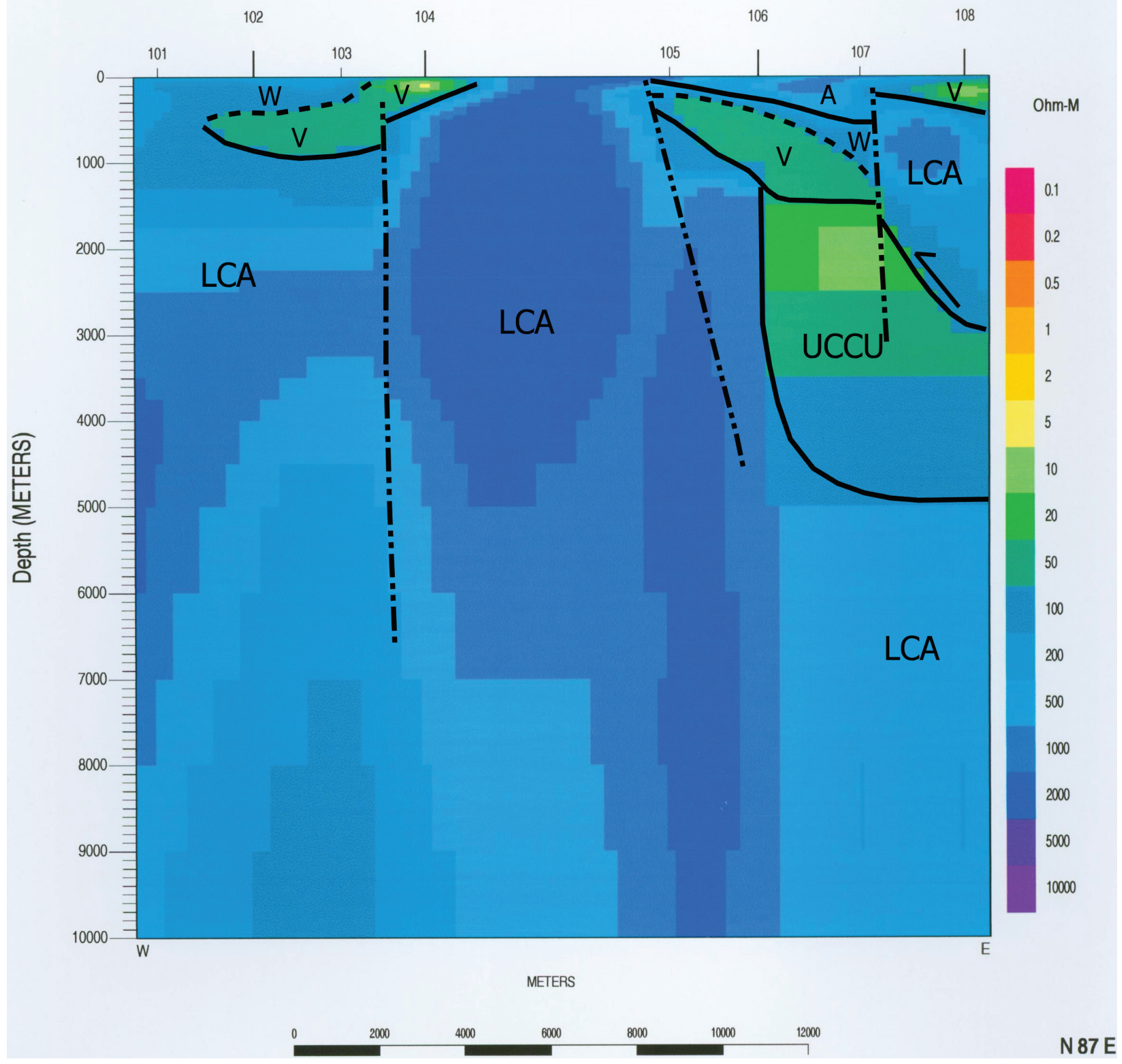

Figure 9. 2-D modeling results for Profile 3. Model 92. Refer to table 4 for key to geologic unit abbreviations. 


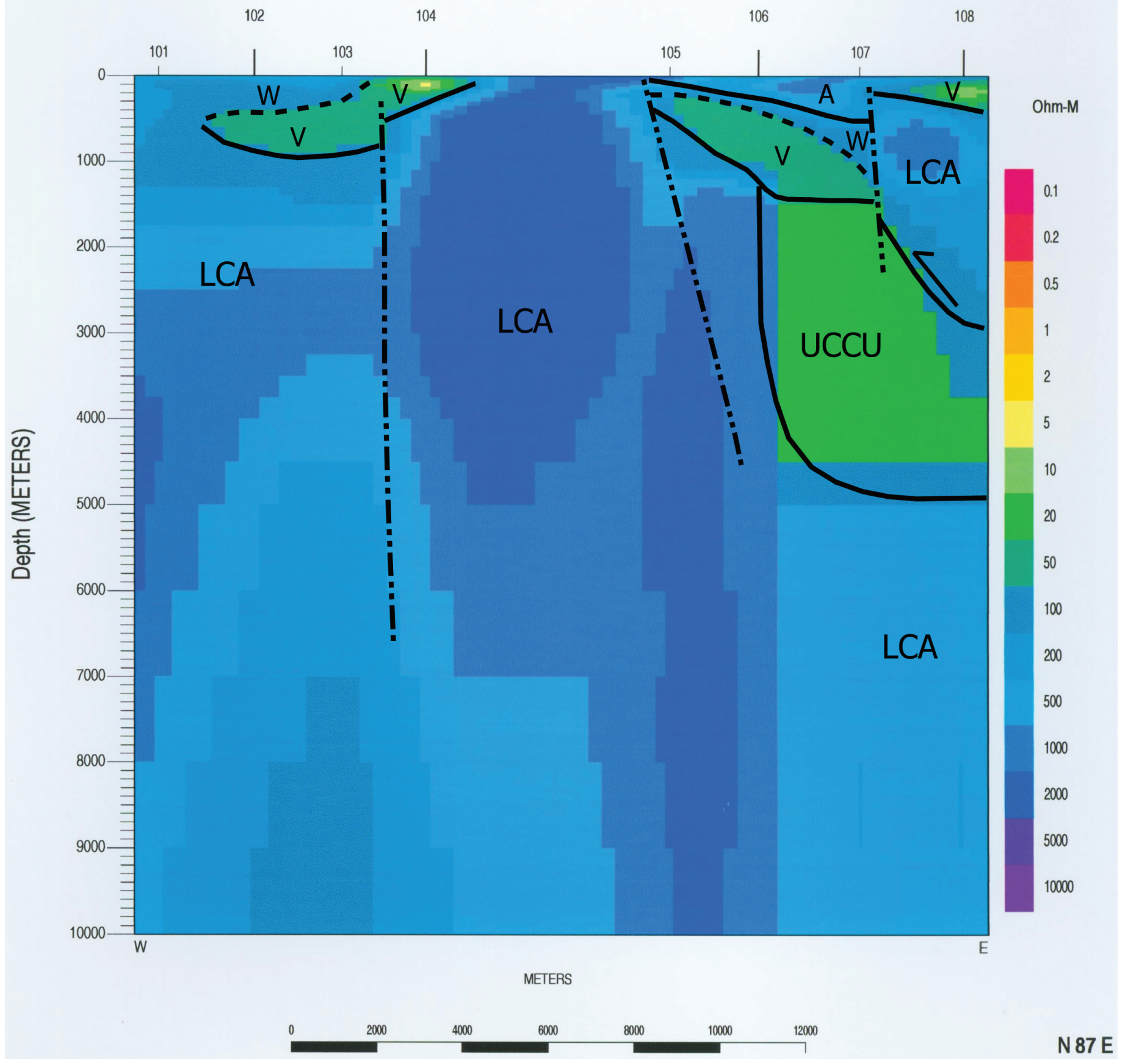

Figure 10. 2-D modeling results for Profile 3. Model 93. Refer to table 4 for key to geologic unit abbreviations. 

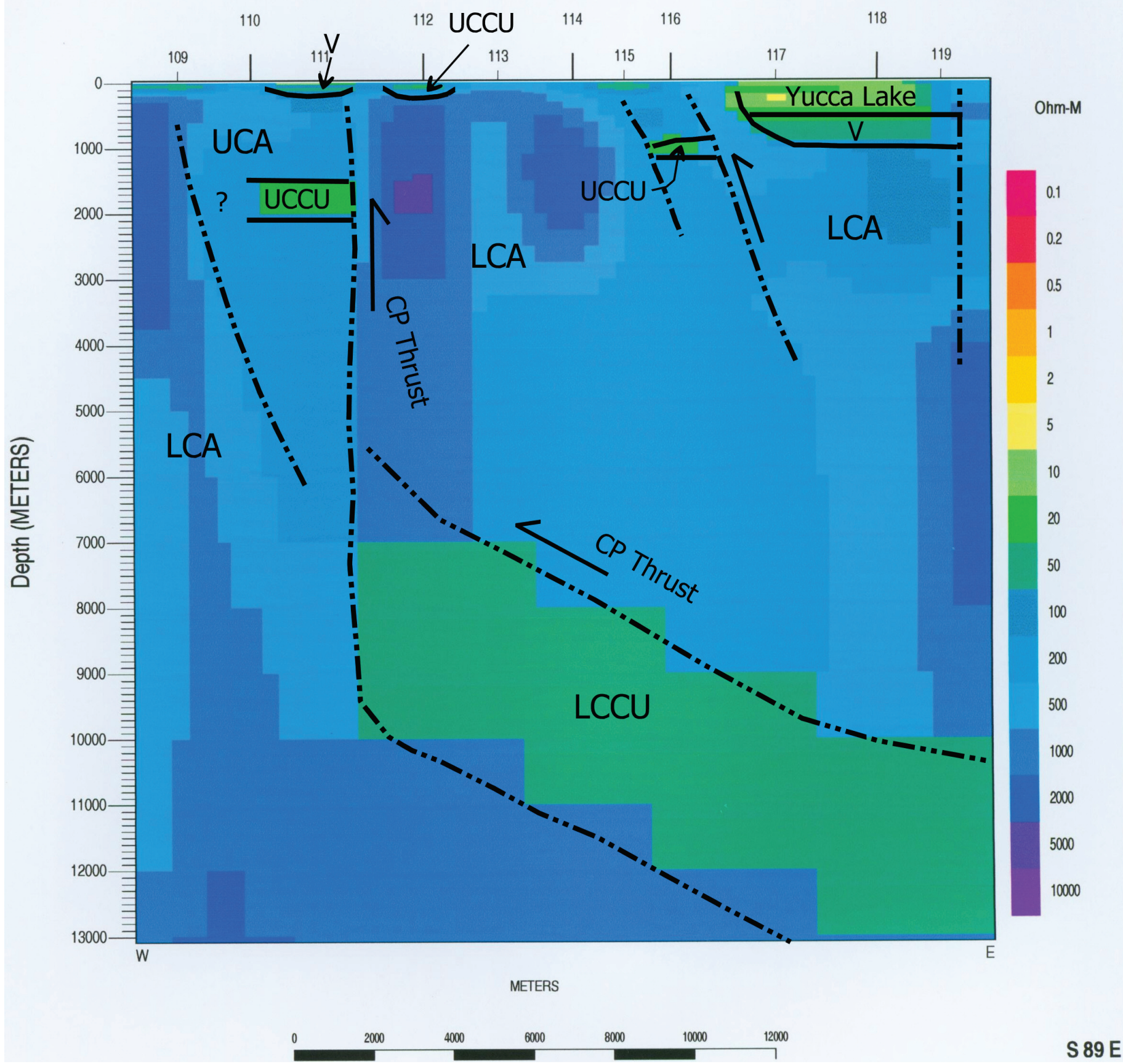

Figure 11. 2-D modeling results for Profile 4. Model 53. Refer to table 4 for key to geologic unit abbreviations. 


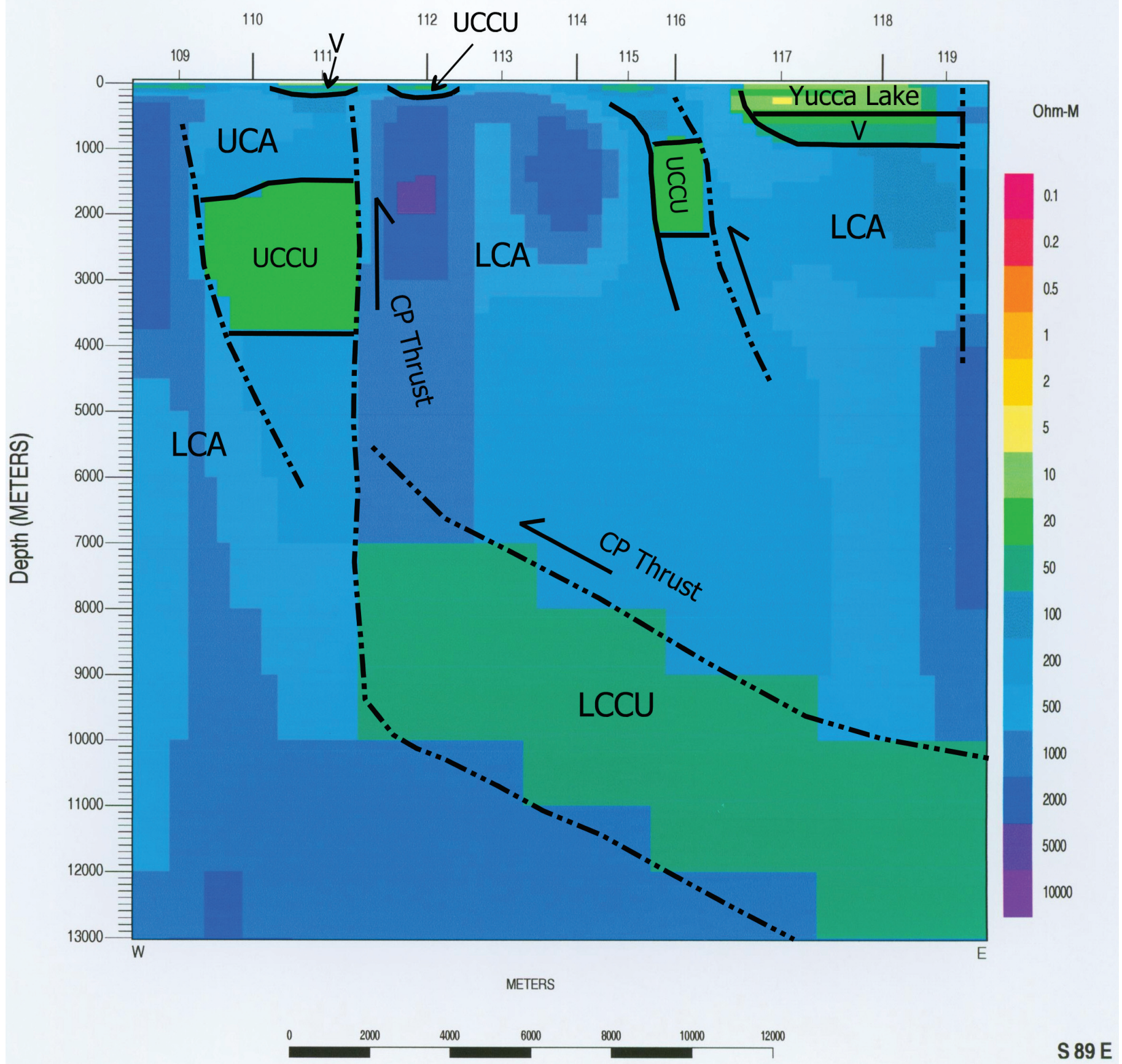

Figure 12. 2-D modeling results for Profile 4. Model 60. Refer to table 4 for key to geologic unit abbreviations. 
The minimum depth to the top of the LCCU that is overlain by the LCA is interpreted to be approximately $6-7 \mathrm{~km}$ depth. A 3-km thick LCCU unit has been modeled in figures 11 and 12. A thinner LCCU (less than $1 \mathrm{~km}$ ) at greater depths is also permissible but cannot be reliably resolved by regional MT measurements. As discussed in Profiles 1 and 2, the existence of the moderately conductive inferred LCCU at depth is not required by the MT data.

Conductive (5-20 ohm-m) sediments under Yucca Lake are clearly visible in both models and overlay more resistive (50 ohm-m), inferred volcanic units that outcrop at the eastern edge of Yucca Lake.

The UCCU in both models is terminated just east of station 11 by what is inferred to be the $\mathrm{CP}$ thrust or a related fault. The Carpetbag fault or a related fault may control the extent of the UCCU near stations 15 and 16. The CP thrust, controlling the extent of the LCCU, is interpreted to be sub-vertical near station 11 down to $6 \mathrm{~km}$ depth, and then dips eastwards.

A comparison of models 53 and 60 with polar plots in Williams and others (2005d) indicates that the geology at most stations along Profile 4 is generally 3-D in character about 10 $\mathrm{km}$ away in distance or depth or both. Stations 9 and 15 appear to be 3-D from the near-surface to at least $10 \mathrm{~km}$ away in depth or distance or both. Station 19 is 3-D about $2 \mathrm{~km}$ in depth or distance or both. The tipper strike indicates that the resistivity structure is sub-parallel to the profile at station 18 from the near-surface to over $10 \mathrm{~km}$ in depth or distance or both.

\section{Profile 5 - Control Well ER12-2}

Profile 5, the shortest profile with only two MT stations: 43 and 44, lies on the northwestern edge of Yucca Flat and is not far from well ER12-2. The 2-D MT modeling, with only two stations, was not able to very satisfactorily model the data because of probable structure near the stations but also outside the profile (pl. 1). Two models, 24 and 31, are presented for Profile 5 (figures 13 and 14). The difference between the two models shows with the thickness of the conductive UCCU, which is inferred to overlay the more resistive LCA. The minimum UCCU thickness in the upper $5 \mathrm{~km}$ of the section is, under stations 43 and 44, a 10-50 ohm-m conductor that is approximately $2500-\mathrm{m}$ thick in model 31 (fig. 14). The maximum thickness of the UCCU is inferred to be almost 4 $\mathrm{km}$ thick in model 24 (fig. 13) assuming the underlying layer (LCA?) is only $50 \mathrm{ohm}-\mathrm{m}$ (not likely, based on resistivity logs ER6-1 and ER8-1 where the LCA resistivity ranged from 100-20,000 ohm-m).

Neither of the interpretations of the data recorded at stations 43 and 44 matches the resistivity information acquired from well ER12-2 that is shown in both models on the far eastern edge at its approximate location. The computed misfits (fig. A30) did not allow using the same resistivity distribution seen in well ER12-2 any closer to stations 43 and 44 than shown in both models. The stations are too isolated to reliably model the sub-parallel structure indicated by the tipper strike at both stations (Williams and others, 2005e).

\section{Profile 6a - Across Quartzite Ridge}

The MT stations along Profile 6, which crosses Quartzite Ridge and the Climax Stock have been subdivided into two sub-profiles: Profiles 6a and 6b. Profile 6a consists of stations 45-49. Two interpretations, models 99 and 100 (figures 15 and 16), are presented for Profile 6a. As discussed above, these models are possible representations of the subsurface geology. While the MT data support these representations, detailed resolution of structures at depth is limited. The western half of the profile is on Quartzite Ridge where, under stations 45 and 46 , the conductive UCCU (20-100 ohm-m) overlies the resistive LCA (200 ohm-m) and possibly the LCCU (100 ohm-m), which is interpreted to be more electrically resistive in this area. The UCCU, in the upper $5 \mathrm{~km}$ under stations 45 and 46 , is about $2 \mathrm{~km}$ thick.

The Tippinip fault crosses the section near station 47 and appears to be within very resistive material that may be marble. Station 48 is located on resistive material that is interpreted, from the geologic image in plate 1 and nearby well ER8-1, to be granitic material of the Climax Stock (MGCU in figures 15 and 16). Station 49, also interpreted to be overlying marble at depth, is near the Area 13 fault that may be a boundary fault for the Climax Stock. The difference between model 99 (fig. 15) and model 100 (fig. 16) is that the shallow, resistive volume under station 49 that is labeled "V" for volcanic material has been removed in model 100 . The calculated model responses are similar (figures A36 and A39).

A comparison of models 99 and 100 with polar plots in Williams and others (2005e) indicates that the geology at station 45 is 3-D at a depth of about $20 \mathrm{~km}$ or at a distance away of about $20 \mathrm{~km}$ or both. Station 46 is 3-D from the near-surface to about $1 \mathrm{~km}$ in depth or distance or both. The geology near Station 47 is 3-D at about $500 \mathrm{~m}$ in depth or distance or both.

\section{Profile 6b - Across Quartzite Ridge}

Profile $6 \mathrm{~b}$ is a generally northwest- to southeast-trending group of three MT stations including stations 48, 50, and 51. Two different interpretations are presented for Profile $6 \mathrm{~b}$. Model 1 (fig. 17) is the base model that shows stations 48 and 50 to be on resistive granite of the Climax Stock that overlies the resistive LCA to the southeast. There are some small zones of possible mineral alteration (conductive material) in the near surface. Station 51 may be overlying the UCCU at about 200 $\mathrm{m}$ depth. The thickness of the UCCU under station 51 ranges from $500 \mathrm{~m}$ in model 1 (fig. 17) to about $2500 \mathrm{~m}$ in model 9 (fig. 18). The extent of the inferred UCCU to the northwest (towards station 50 from 51) is not resolvable due to the large station spacing between stations 50 and 51 .

In model 9 a $2500-m$ thick UCCU has been extended northwest from station 51 toward station 50. It is permissible that UCCU underlies the intrusive granite under stations 48 and 50, but the MT data does not require it. The minimum permissible depth of the postulated UCCU beneath stations 


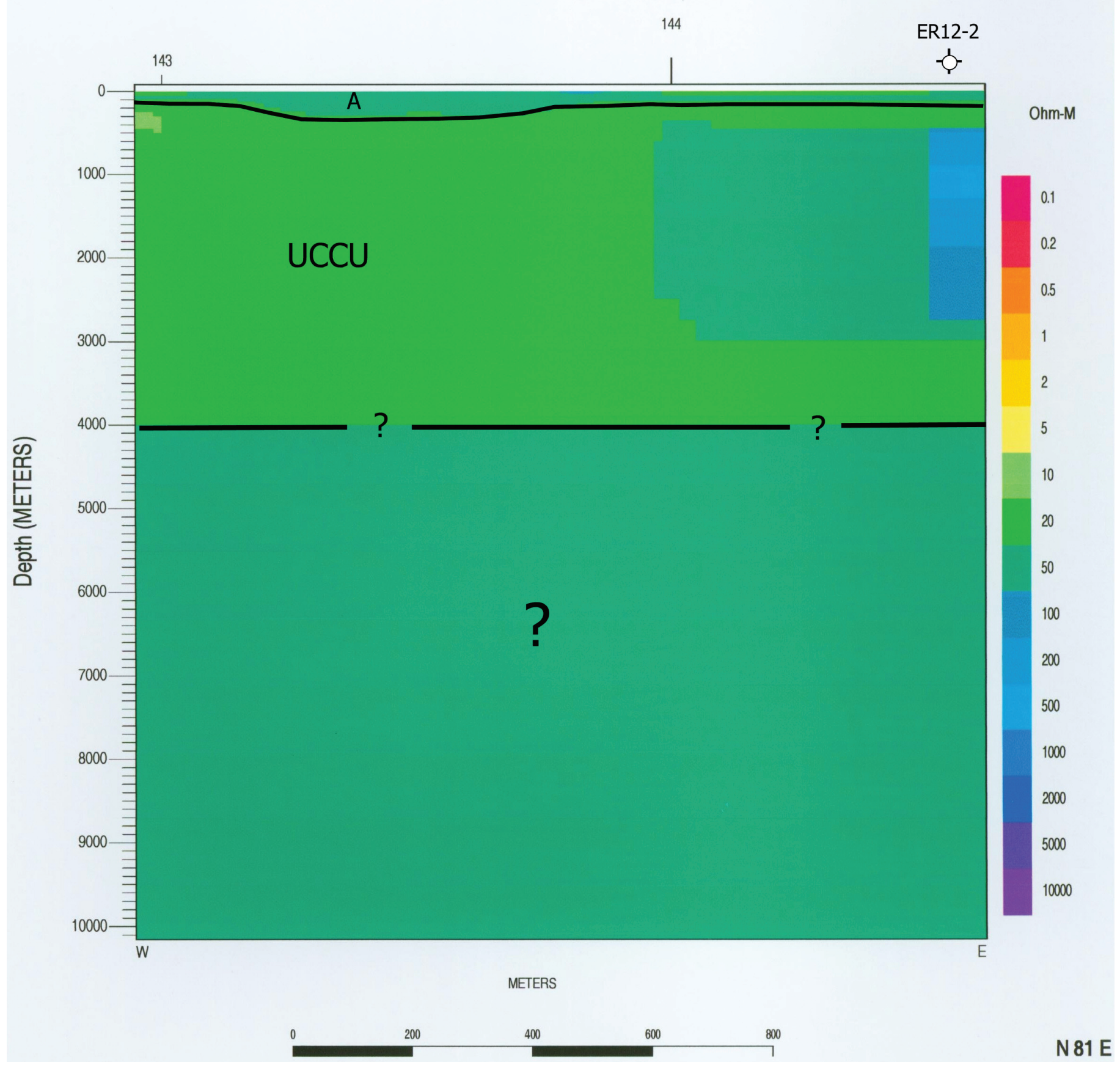

Figure 13. 2-D modeling results for Profile 5. Model 24. Refer to table 4 for key to geologic unit abbreviations. 


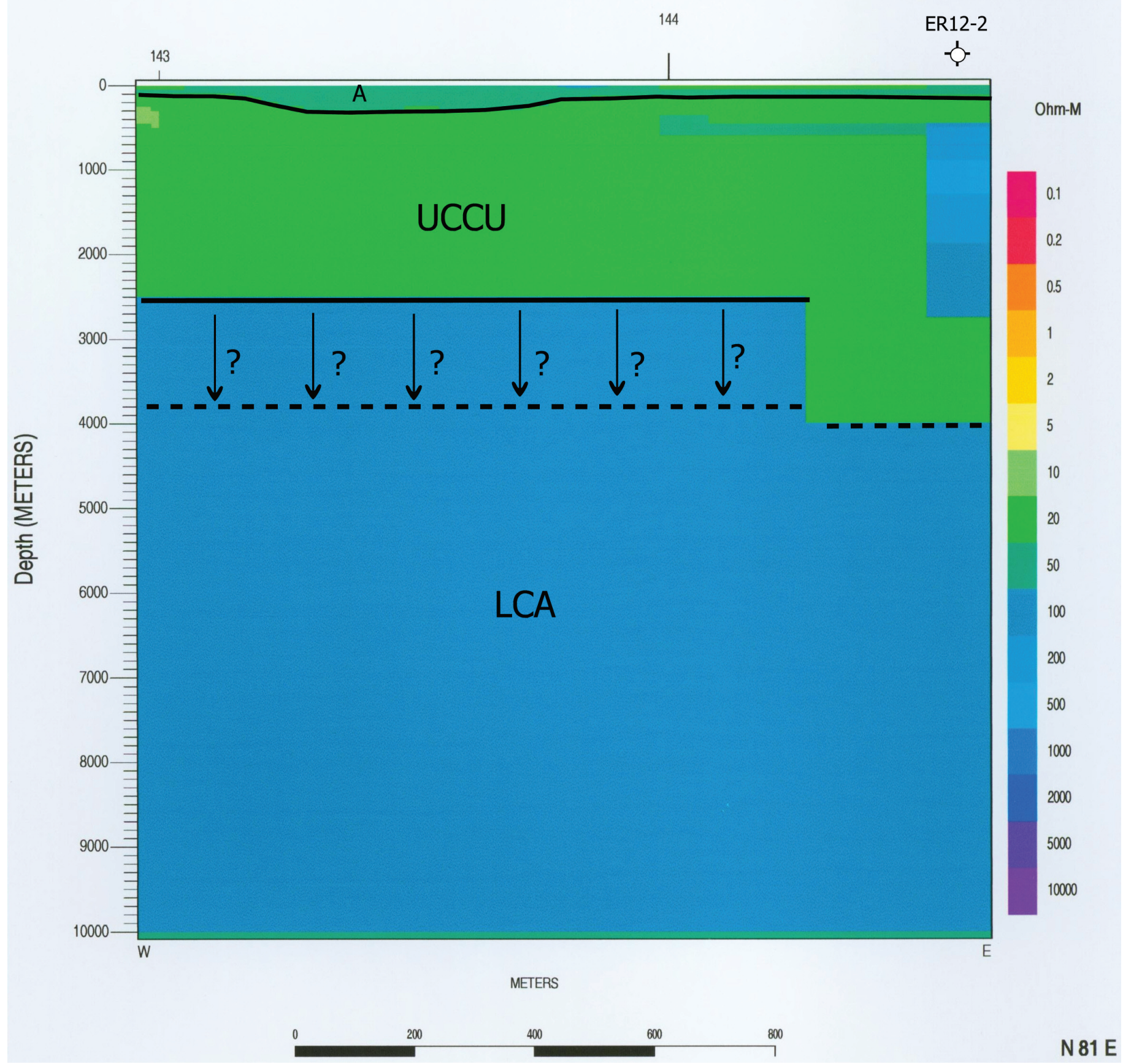

Figure 14. 2-D modeling results for Profile 5. Model 31. Refer to table 4 for key to geologic unit abbreviations. 

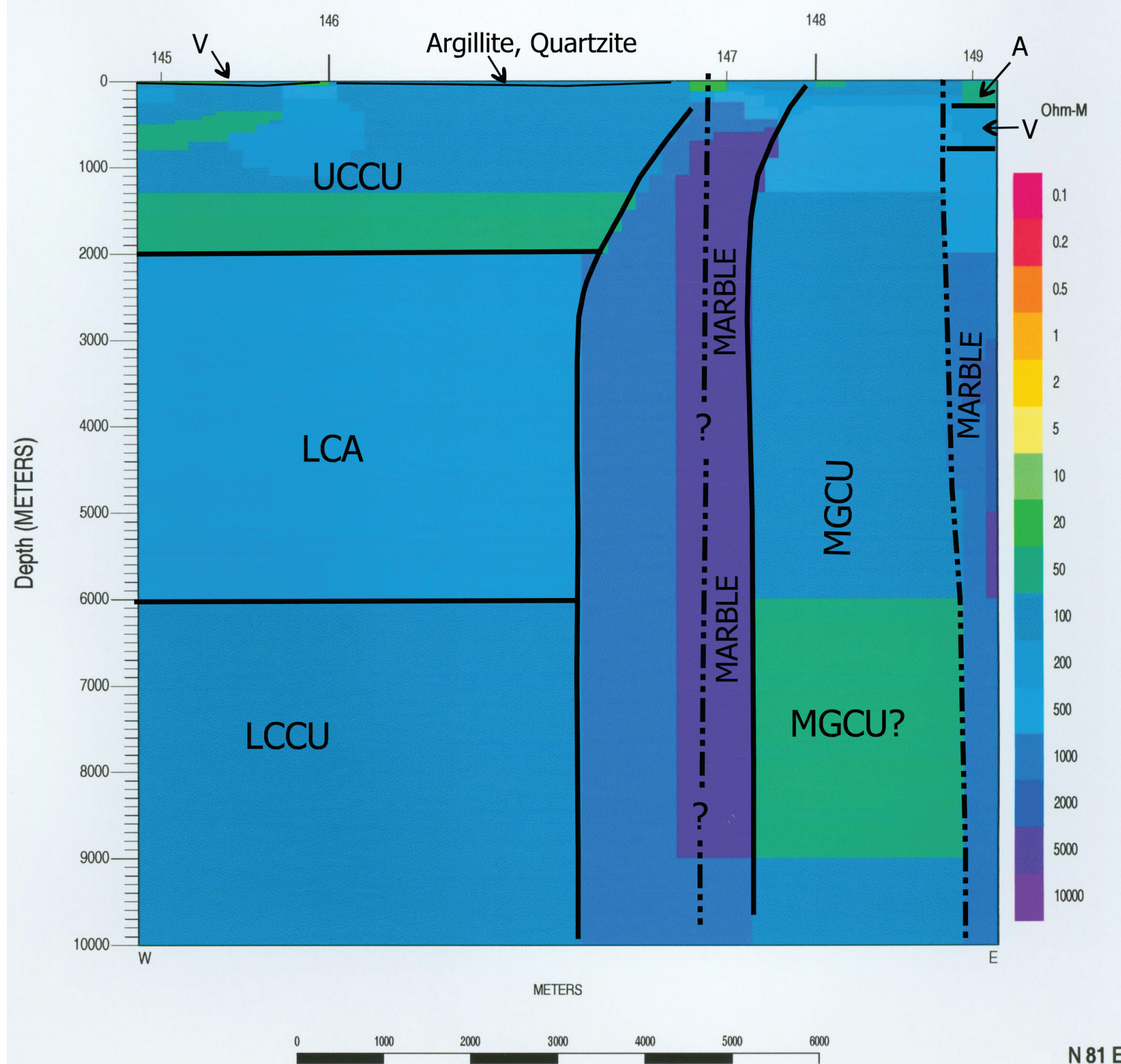

Figure 15. 2-D modeling results for Profile 6a. Model 99. Refer to table 4 for key to geologic unit abbreviations. MGCU is Mesozoic granitic intrusive unit (Climax Stock?).vv 


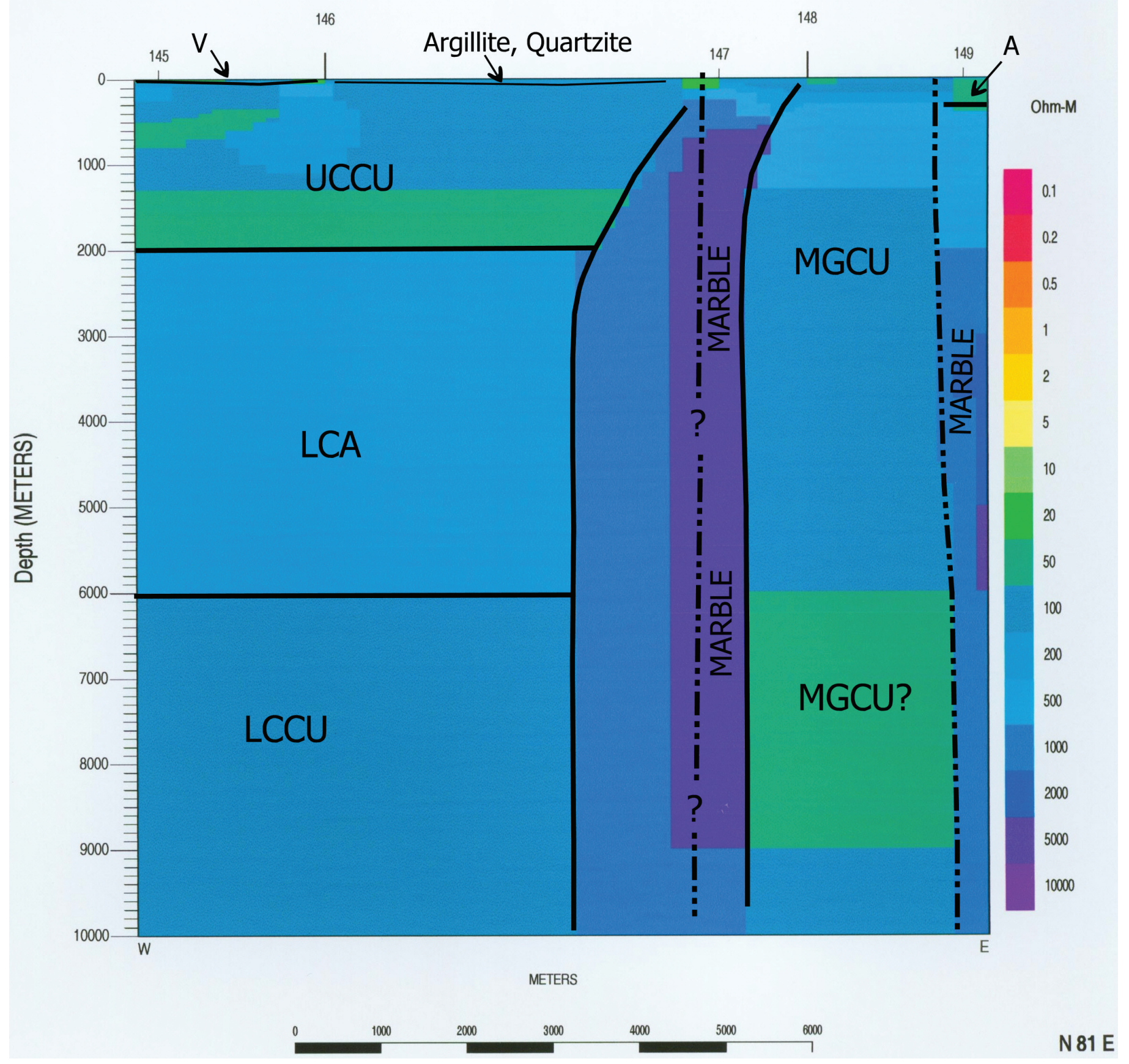

Figure 16. 2-D modeling results for Profile 6a. Model 100. Refer to table 4 for key to geologic unit abbreviations. MGCU is Mesozoic granitic intrusive unit (Climax Stock?). 
48 and 50 is approximately $3 \mathrm{~km}$. The 2-D modeling cannot resolve whether the UCCU could have a thickness of less than $1 \mathrm{~km}$ below stations 48 and 50 below $6 \mathrm{~km}$ depth.

A comparison of models 1 and 9 with polar plots in Williams and others (2005e) indicates that the geology at station 50 is 3-D at about $3 \mathrm{~km}$ depth or in distance or both. The tipper strike in Williams and others (2005e) indicates that the resistivity structure is sub-parallel to the profile at stations 48 and 51 from the near-surface to over $25 \mathrm{~km}$ depth or in distance or both. Models 1 and 9 are computationally equivalent because of the sparse number of, and distance between, MT stations.

\section{Profile 7 - North Central Yucca Flat}

Profile 7 (fig. 2) crosses many of the dominant fault structures of Yucca Flat and consists of MT stations 29-36. Three computationally equivalent interpretations for Profile 7 (models 44, 51, and 52) are presented. As discussed above, these models are possible representations of the subsurface geology. While the MT data support these representations, detailed resolution of structures at depth is limited. The primary difference between the models is the thickness, depth, and continuity of the Chainman Shale in the UCCU under stations 29, 30, and 31. In model 44 (fig. 19) the UCCU under station 29 is shallow and is approximately $1 \mathrm{~km}$ thick. In models 51 and 52 (figures 20 and 21), the inferred UCCU under station 29 is approximately $3 \mathrm{~km}$ thick. In model 44 , the UCCU is approximately $1 \mathrm{~km}$ thick under stations 30 and 31 , but the depth to the top of the UCCU under station 30 is approximately $500 \mathrm{~m}$ and about $2 \mathrm{~km}$ under station 31 . The $\mathrm{CP}$ thrust is interpreted to have positioned the LCA over the UCCU under station 31. The 2-D modeling cannot resolve whether or not the inferred LCCU is located at 8-10 km depth as shown in models 44,51 , and 52. Both the LCCU and UCCU appear to be fault controlled by the $\mathrm{CP}$ thrust.

In model 51 (fig. 20) the UCCU thickness under station 31 has been increased to $3 \mathrm{~km}$ and the depth extent to $5 \mathrm{~km}$. It is also interpreted that the UCCU may be in proximity to the LCCU at 5-6 km depth. The absolute boundary between the UCCU and LCCU at this depth could not be resolved.

In model 52 (fig. 21) the width of the UCCU beneath station 31 is approximately $1500 \mathrm{~m}$. This is reduced from the 2500-m UCCU width beneath station 31 in models 44 and 51 . In the upper $5 \mathrm{~km}$, while the computed modeling misfits (fig. A54) allowed moving the LCA western vertical boundary between stations 31 and 32 approximately 1500 $\mathrm{m}$ to the west (when compared to models 44 and 51), the modeling did not allow moving the boundary directly underneath station 31. Also, the modeling did not allow moving the LCA western boundary east of station 32. In model 52

(fig. 21) the LCA western boundary is located slightly east of station 31 .

The eastern end of the profile is dominated by normal faults. The eastward-dipping Carpetbag and a component of the $\mathrm{CP}$ thrust faults are interpreted to cross between stations 32 and 33. Alluvial and volcanic units appear to be affected by the eastward-dipping Yucca fault that is interpreted to cross between stations 33 and 34 and unnamed westwarddipping faults that are located between stations 35 and 36 .

A comparison of models 44, 51, and 52 with polar plots in Williams and others (2005f) indicates that the geology at stations 29 and 31-36 is 3-D at about $20 \mathrm{~km}$ in depth or in distance away or both. The geology beneath station 30 is 3-D at about $3 \mathrm{~km}$ in depth or in distance away or both.

\section{Summary}

The 51 MT data stations collected by the USGS in 2003 have helped to characterize the deep resistivity structure in the pre-Tertiary geology beneath the Yucca Flat area of the Nevada Test Site. The character, thickness, and lateral extent of the Chainman Shale and Eleana Formation that comprise the Upper Clastic Confining Unit (UCCU) are generally well determined in the upper $5 \mathrm{~km}$. Inferences can be made regarding the presence of the Lower Clastic Confining Unit (LCCU) at depths below $5 \mathrm{~km}$. Large fault structures such as the $\mathrm{CP}$ Thrust fault, the Carpetbag fault, and the Yucca fault that cross Yucca Flat are also discernable as are other smaller faults. The subsurface electrical resistivity distribution and inferred geologic structures determined by this investigation should help constrain the hydrostratigraphic framework model that is under development for the Yucca Flat CAU and in understanding the effects on ground-water flow in the area subsequent to a nuclear test. 


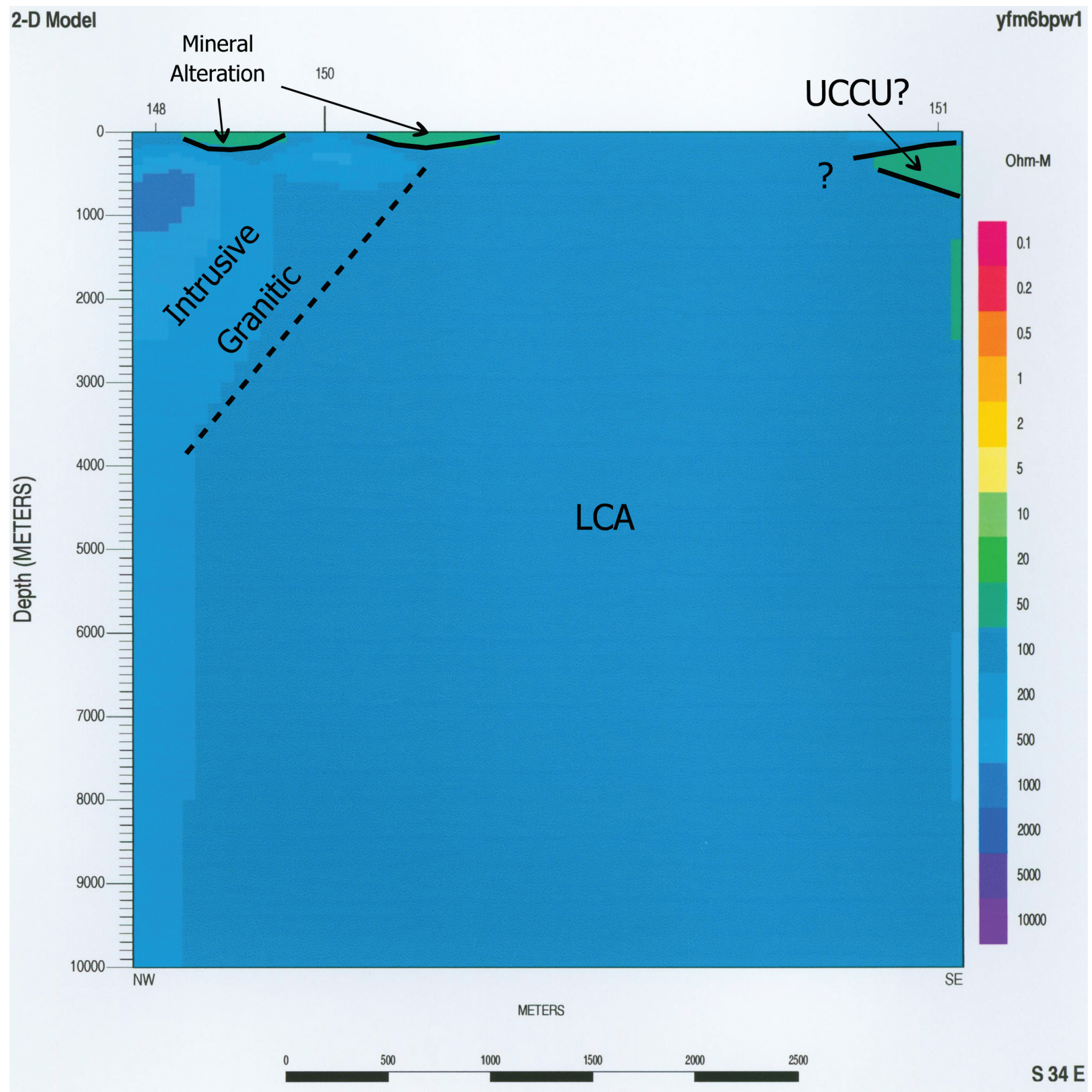

Figure 17. 2-D modeling results for Profile $6 \mathrm{~b}$. Model 1. Refer to table 4 for key to geologic unit abbreviations. 


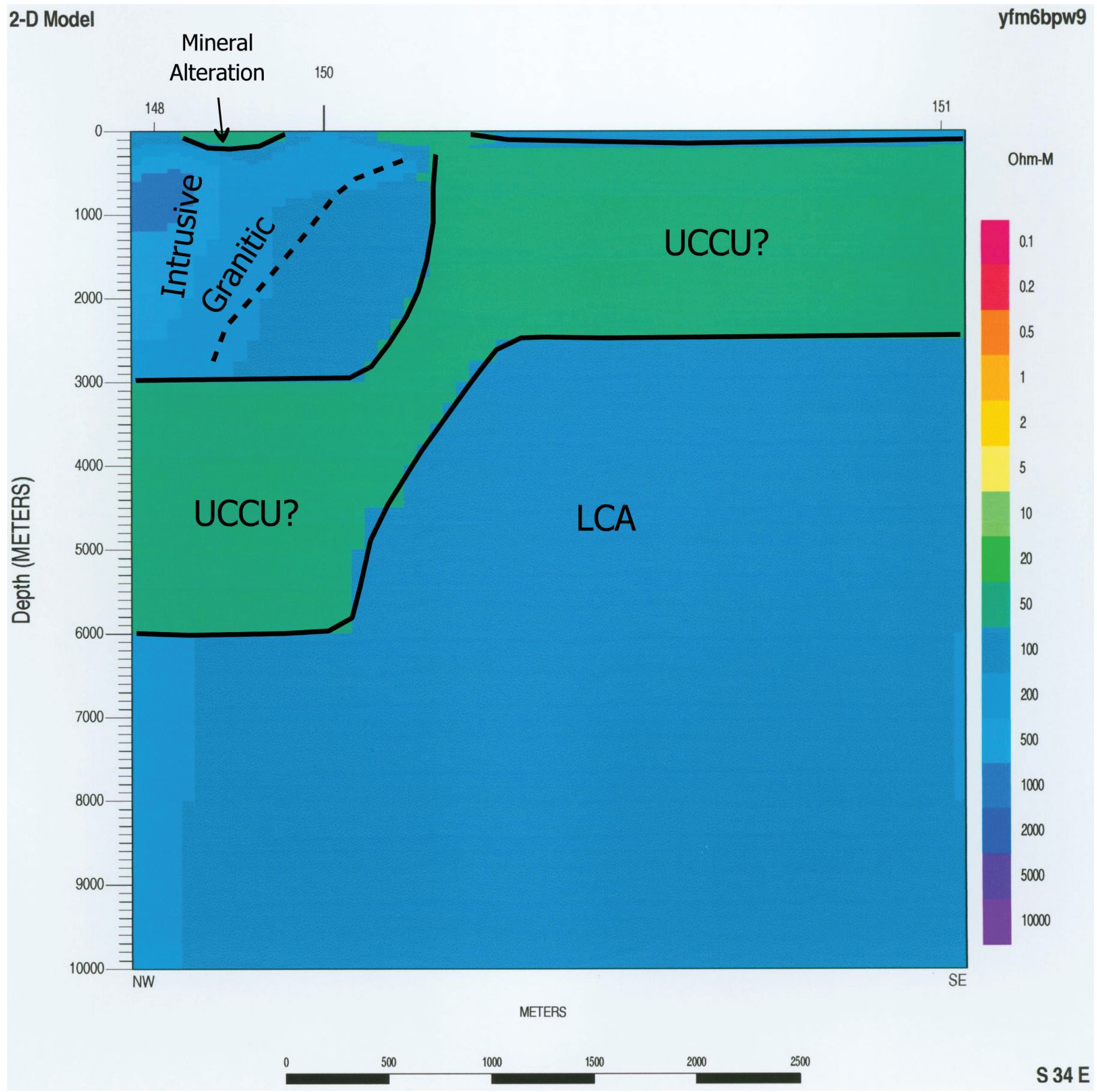

Figure 18. 2-D modeling results for Profile 6b. Model 9. Refer to table 4 for key to geologic unit abbreviations. 


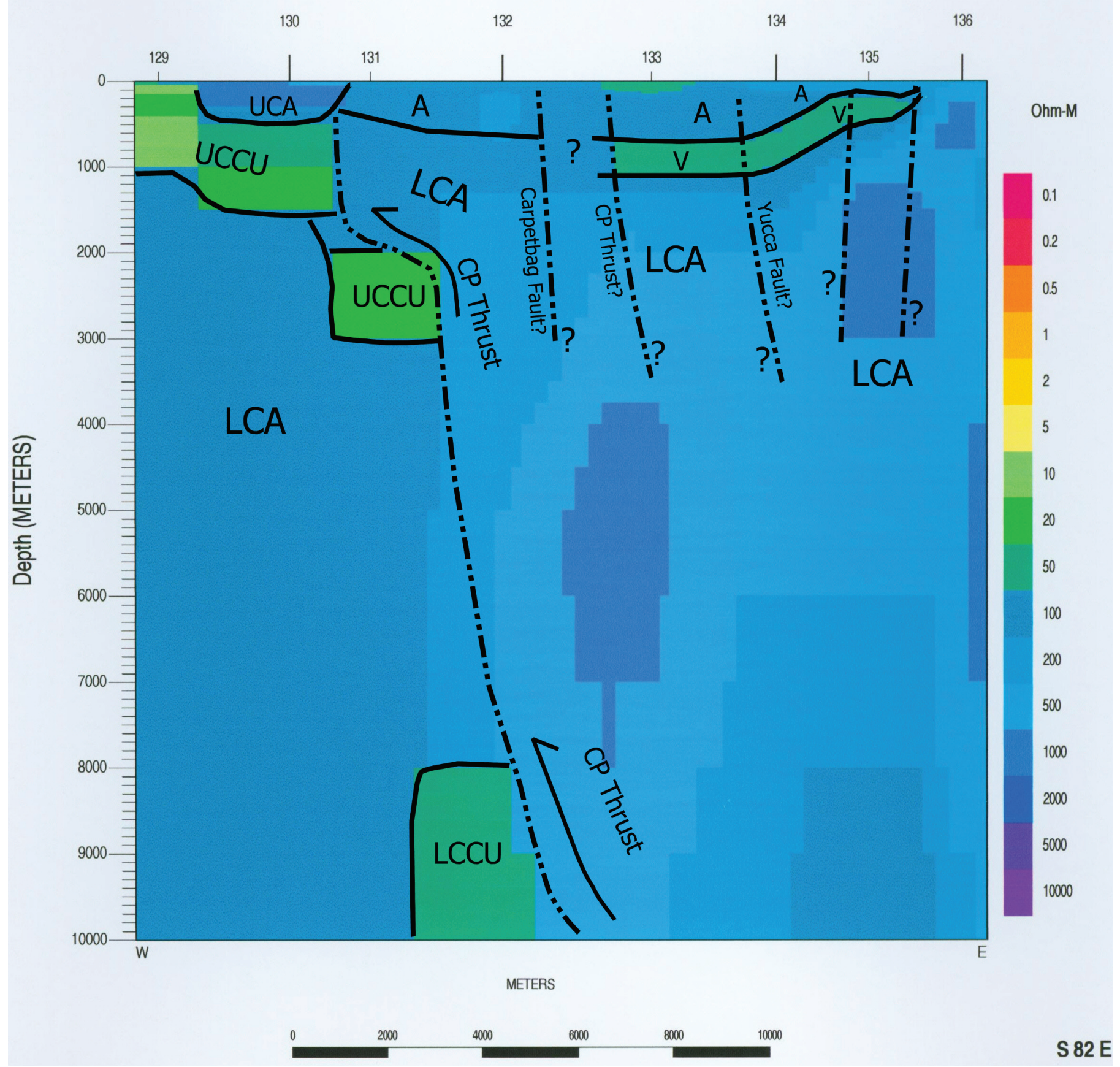

Figure 19. 2-D modeling results for Profile 7. Model 44. Refer to table 4 for key to geologic unit abbreviations. 


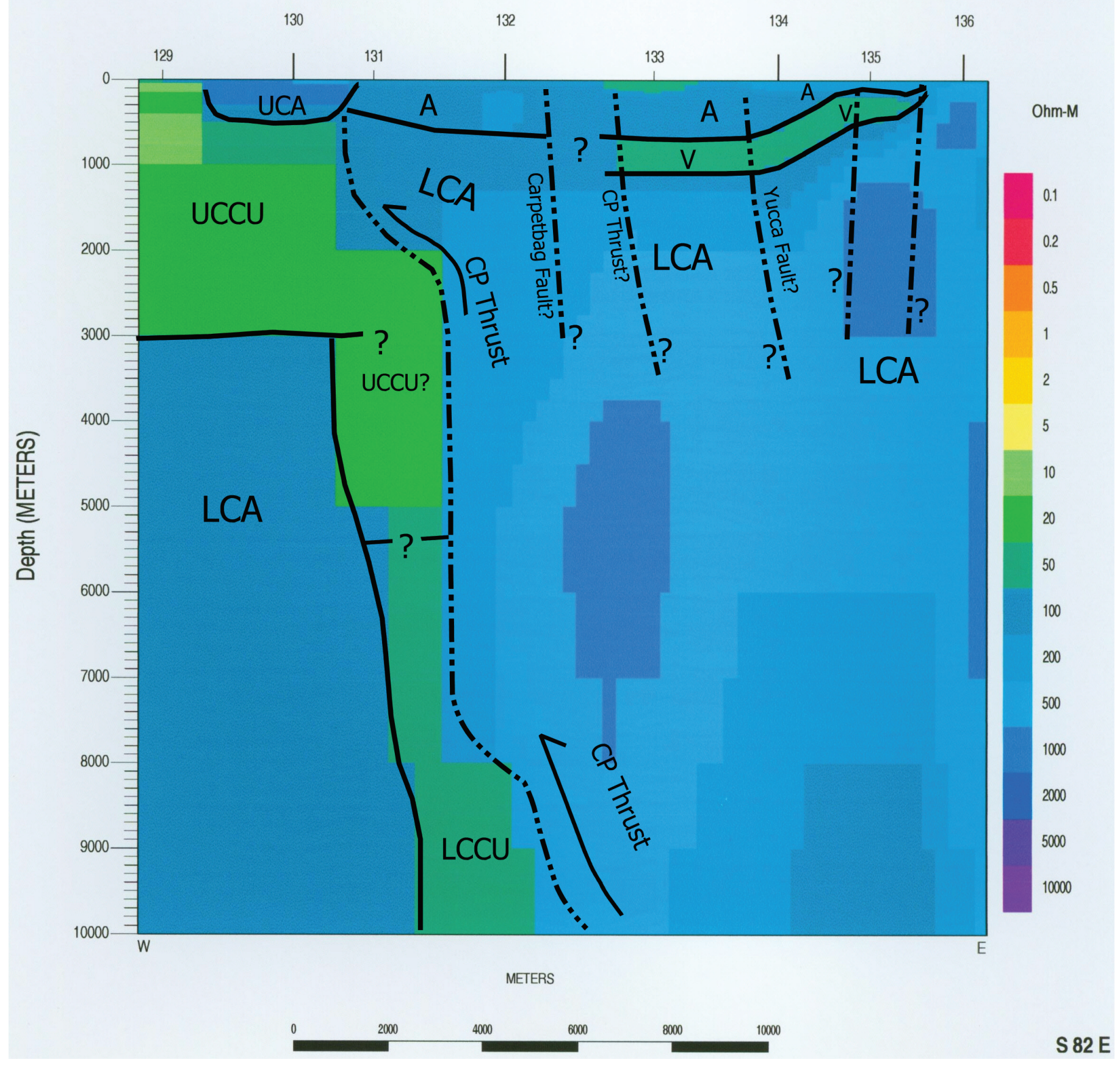

Figure 20. 2-D modeling results for Profile 7. Model 51. Refer to table 4 for key to geologic unit abbreviations. 
2-D Model

yfm7pw52

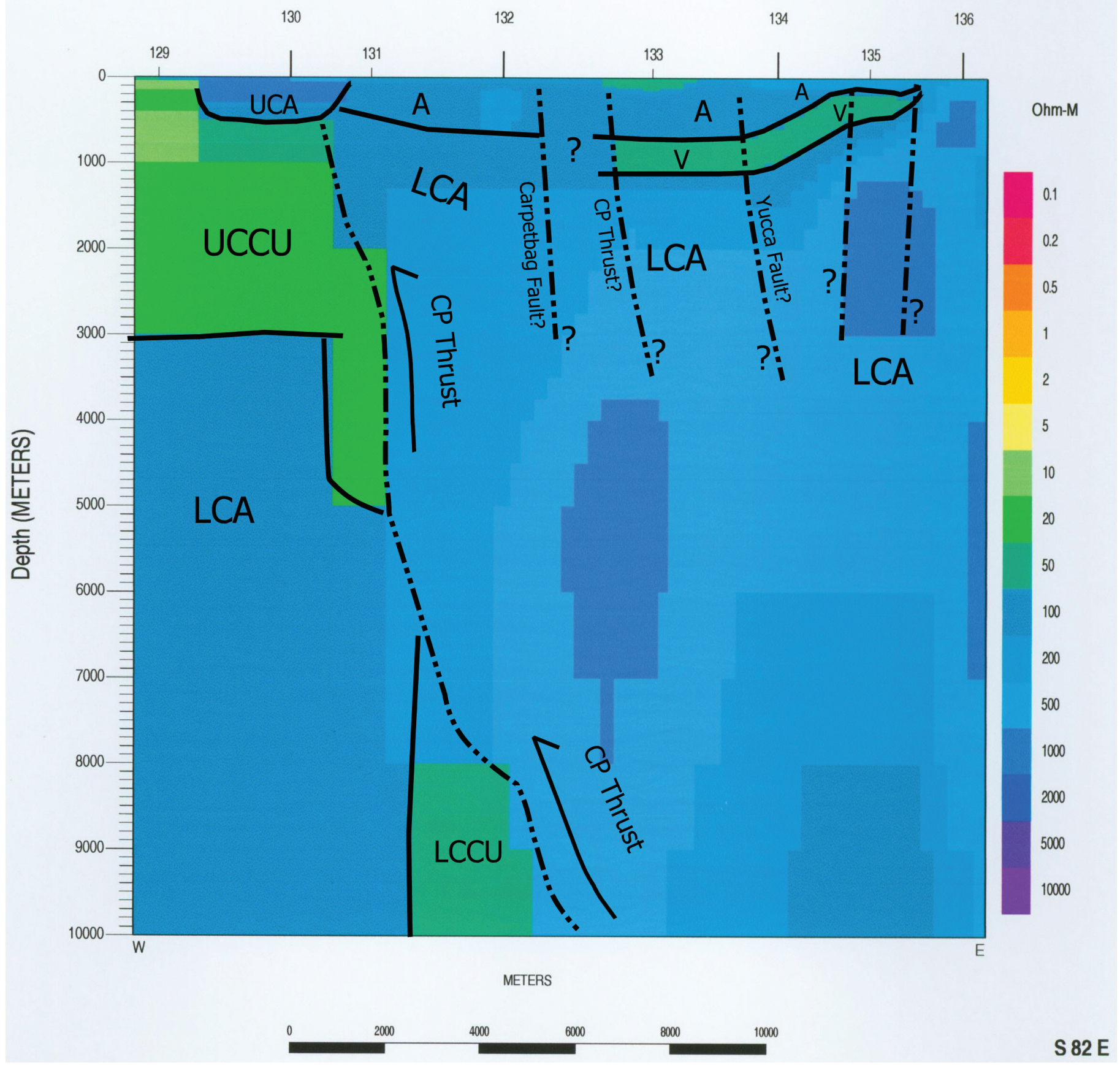

Figure 21. 2-D modeling results for Profile 7. Model 52. Refer to Table 4 for key to geologic unit abbreviations. 


\section{References Cited}

Bechtel Nevada, 2006, A hydrostratigraphic model and alternatives for the groundwater flow and contaminant transport model of Corrective Action Unit 97: Yucca Flat-Climax Mine, Lincoln and Nye counties, Nevada: DOE/NV/117181119, Las Vegas, NV.

Bendat, J.S., and Piersol, A.G., 1971, Random data-analysis and measurement procedures: New York, Wiley Interscience, $407 \mathrm{p}$.

Cole, J.C., Harris, A.G., and Wahl, R.R., 1997, Subcrop geologic map of pre-Tertiary rocks in the Yucca Flat and northern Frenchman Flat areas, Nevada Test Site, southern Nevada: U.S. Geological Survey Open-File Report 97-678, scale $1: 48,000,24 \mathrm{p}$.

Dobrin, M.D., and Savit, C.H., 1988, Introduction to geophysical prospecting (4th ed.): New York, McGraw-Hill, $867 \mathrm{p}$.

Eberhart-Phillips, Donna, Stanley, W.D., Rodriguez, B.D., and Lutter, W.J., 1995, Surface seismic and electrical methods to detect fluids related to faulting: Journal of Geophysical Research, v. 100, no. B7, p. 12919-12936.

Egbert, G.D., 1997, Robust multiple station magnetotelluric data processing: Geophysics Journal International, 130, p. 475-496.

EMI, 1996, MT-1 magnetotelluric system operation manual, version 3.2: Richmond, Calif., ElectroMagnetic Instruments, Inc., $220 \mathrm{p}$.

EMI, 2002, MT24/LF System Operation and Maintenance Manual, version 1.0: Richmond, Calif., ElectroMagnetic Instruments, Inc., $72 \mathrm{p}$.

Gamble, T.D., Goubau, W.M., and Clarke, J., 1979, Error analysis for remote reference magnetotellurics: Geophysics, v. 44 , no. 5 , p. $959-968$.

Keller, G.V., 1987, Rock and mineral properties, in Nabighian, M.N., ed., Electromagnetic methods in applied geophysics theory: Tulsa, Okla., Society of Exploration Geophysicists, v. 1, p. $13-51$.

Keller, G.V., 1989, Electrical properties, in Carmichael, R.S., ed., Practical handbook of physical properties of rocks and minerals: Boca Raton, Fla., CRC Press, p. 359-427.

Mackie, Randall, Rieven, Shirley, and Rodi, William, 1997, User's manual and software documentation for twodimensional inversion of magnetotelluric data: GEOTOOLS User's Guide RLM2DI Supplement, 10 p.

Nelson, P.H., and Anderson, L.A., 1992, Physical properties of ash flow tuff from Yucca Mountain, Nevada: Journal of Geophysical Research, v. 97, no. B5, p. 6823-6841.
Palacky, G.J., 1987, Resistivity characteristics of geologic targets, in Nabighian, M.N., ed., Electromagnetic methods in applied geophysics theory: Tulsa, Okla., Society of Exploration Geophysicists, v. 1, p. 53-129.

Prothro, L.B., Leavitt, A.J., Rodriguez, B.D., and Asch, T.H., 2004, Distribution of pre-Tertiary hydrostratigraphic units based on magnetotelluric data, Yucca Flat, Nevada Test Site: Poster at Underground Test Area Technical Working Group Information Exchange Meeting, April 28, 2004.

Reddy, I.K., Rankin, David, and Phillips, R.J., 1977, Three-dimensional modelling in magnetotelluric and magnetic variational sounding: Geophysics Journal of the Royal Astronomical Society, v. 51, p. 313-325.

Rodi, William, and Mackie, R.L., 2001, Nonlinear conjugate gradients algorithm for 2-D magnetotelluric inversion: Geophysics, v. 66, no. 1, p 174-187.

Slate, J.L., Berry, M.E., Rowley, P.D., Fridrich, C.J., Morgan, K.S., Workman, J.B., Young, O.D., Dixon, G.L., Williams, V.S., McKee, E.H., Ponce, D.A., Hildenbrand, T.G., Swadley, W.C., Lundstrom, S.C., Ekren, E.B., Warren, R.G., Cole, J.C., Fleck, R.J., Lanphere, M.A., Sawyer, D.A., Minor, S.A., Grunwald, D.J., Laczniak, R.J., Menges, C.M., Yount, J.C., and Jayko, A.S., 199912, Digital Geologic Map of the Nevada Test Site and Vicinity, Nye, Lincoln, and Clark Counties, Nevada, and Inyo County, California: U. S. Geological Survey Open-File Report OFR 99-554-A, U. S. Geological Survey, Denver, Colorado.

Sternberg, B.K., Washburne, J.C., and Pellerin, Louise, 1988, Correction for the static shift in magnetotellurics using transient electromagnetic soundings: Geophysics, v. 53, p. 1459-1468.

U.S. Department of Energy, 2003, Underground Test Area Fact Sheet: DOE/NV-915, August 2003, 2 pp.

Vozoff, Keeva, 1972, The magnetotelluric method in the exploration of sedimentary basins: Geophysics, v. 37, p. 980-141.

Vozoff, Keeva, 1991, The magnetotelluric method, in Nabighian, M.N., Electromagnetic methods in applied geophysics: Tulsa, Okla., Society of Exploration Geophysicists, v. 2, pt. B, p. 641-711.

Wannamaker, P.E., 1983, Resistivity structure of the northern Basin and Range: Geothermal Resources Council, Special Report No. 13, p. 345-361.

Wannamaker, P.E., Hohmann, G.W., and Ward, S.H., 1984, Magnetotelluric responses of three-dimensional bodies in layered earths: Geophysics, vol. 49, no. 9, p. 1517-1533.

Wannamaker, P.E., Stodt, J.A., and Rijo, L., 1987, PW2D: finite element program for solution of magnetotelluric responses of two-dimensional earth resistivity structure, 
(User documentation): Earth Science Laboratory, University of Utah Research Institute, Salt Lake City, Utah, 40 .

Williams, J.M., Rodriguez, B.D., and Asch, T.H., 2005a, Magnetotelluric data, central Yucca Flat, Nevada Test Site, Nevada: U.S. Geological Survey Open-File Report 2005-

1238, $174 \mathrm{p}$.

Williams, J.M., Rodriguez, B.D., and Asch, T.H., 2005b, Magnetotelluric data, northern Yucca Flat, Nevada Test Site, Nevada: U.S. Geological Survey Open-File Report 2005-

$1239,120 \mathrm{p}$.

Williams, J.M., Rodriguez, B.D., and Asch, T.H., 2005c, Magnetotelluric data, northern Frenchman Flat, Nevada Test Site, Nevada: U.S. Geological Survey Open-File Report 2005-1240, $156 \mathrm{p}$.

Williams, J.M., Rodriguez, B.D., and Asch, T.H., 2005d, Magnetotelluric data, southern Yucca Flat, Nevada Test Site, Nevada: U.S. Geological Survey Open-File Report 2005-

$1241,210 \mathrm{p}$.

Williams, J.M., Rodriguez, B.D., and Asch, T.H., 2005e, Magnetotelluric data across Quartzite Ridge, Nevada Test Site, Nevada: U.S. Geological Survey Open-File Report 2005-1242, 174 p.

Williams, J.M., Rodriguez, B.D., and Asch, T.H., 2005f, Magnetotelluric data, north central Yucca Flat, Nevada Test Site, Nevada: U.S. Geological Survey Open-File Report 2005-1243, 156 p. 


\section{Appendix A: 2-D Resistivity Models, Apparent Resistivities, and Phase Data}

Appendix A contains, for each profile, the 2-D resistivity models with the forward modeling mesh displayed and the observed and calculated apparent resistivity and phase curves for each station. The models are organized by profile number (1-7) and subdivided by the model number shown in the upper right corner of the 2-D model figure.

Each model is presented in the following order:

a) The 2-D resistivity model (without the mesh and interpretations in figures 4-21);

b) The observed and calculated apparent resistivity sounding curves;

c) The observed and calculated impedance phase curves. 


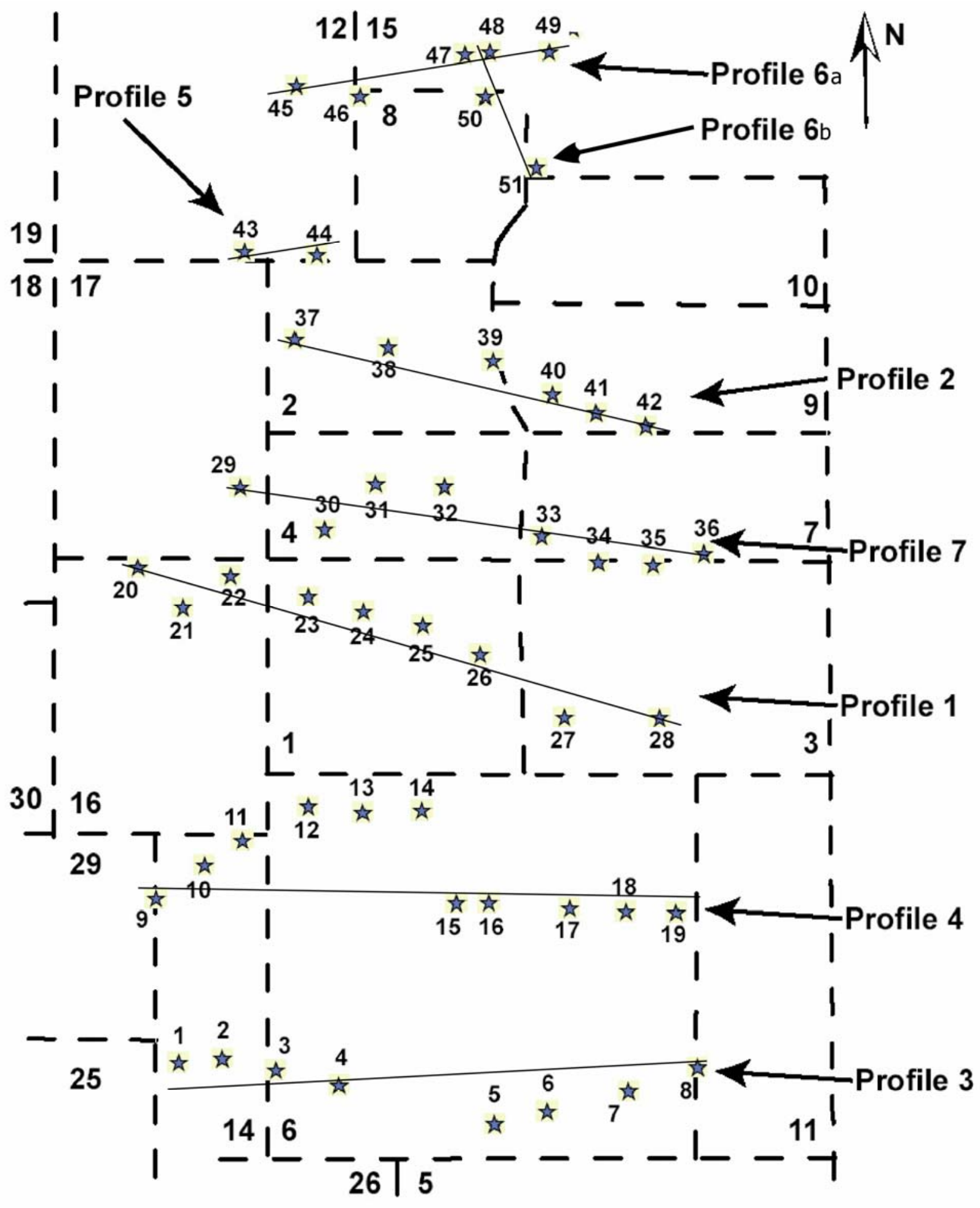

Figure A1. Schematic image showing magnetotelluric (MT) stations in and near Yucca Flat, Nevada Test Site, Nevada grouped into eight profiles. Approximate azimuth of each profile indicated by solid black lines. MT stations acquired in 2003 are numbered 1-51 (stars). Dashed lines are boundaries of Nevada Test Site Areas 1-7, 9-12, 14-19, 25, 26, 29, and 30. 


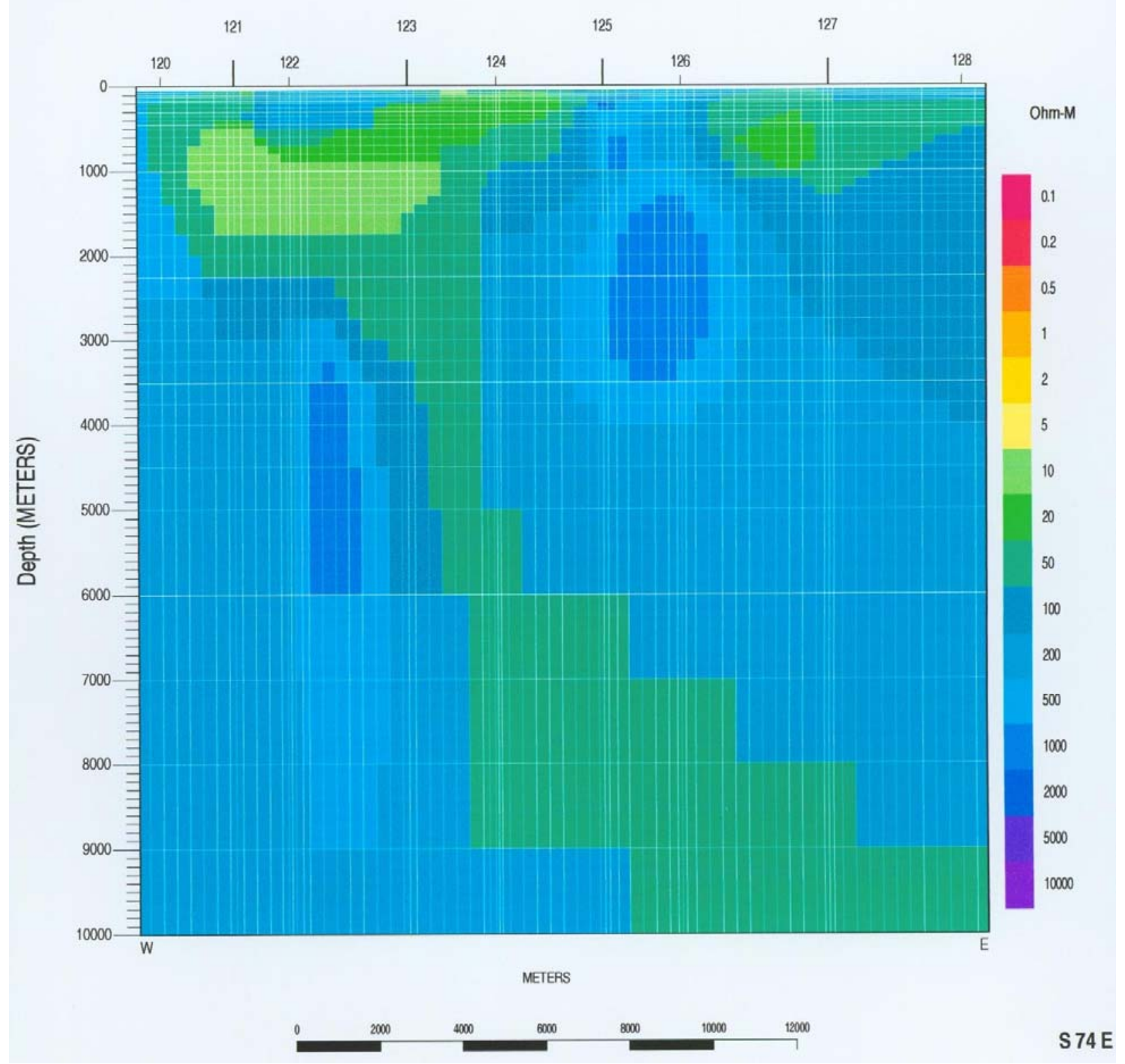

Figure A2. Profile 1, 2-D resistivity model 128 - depth section. 


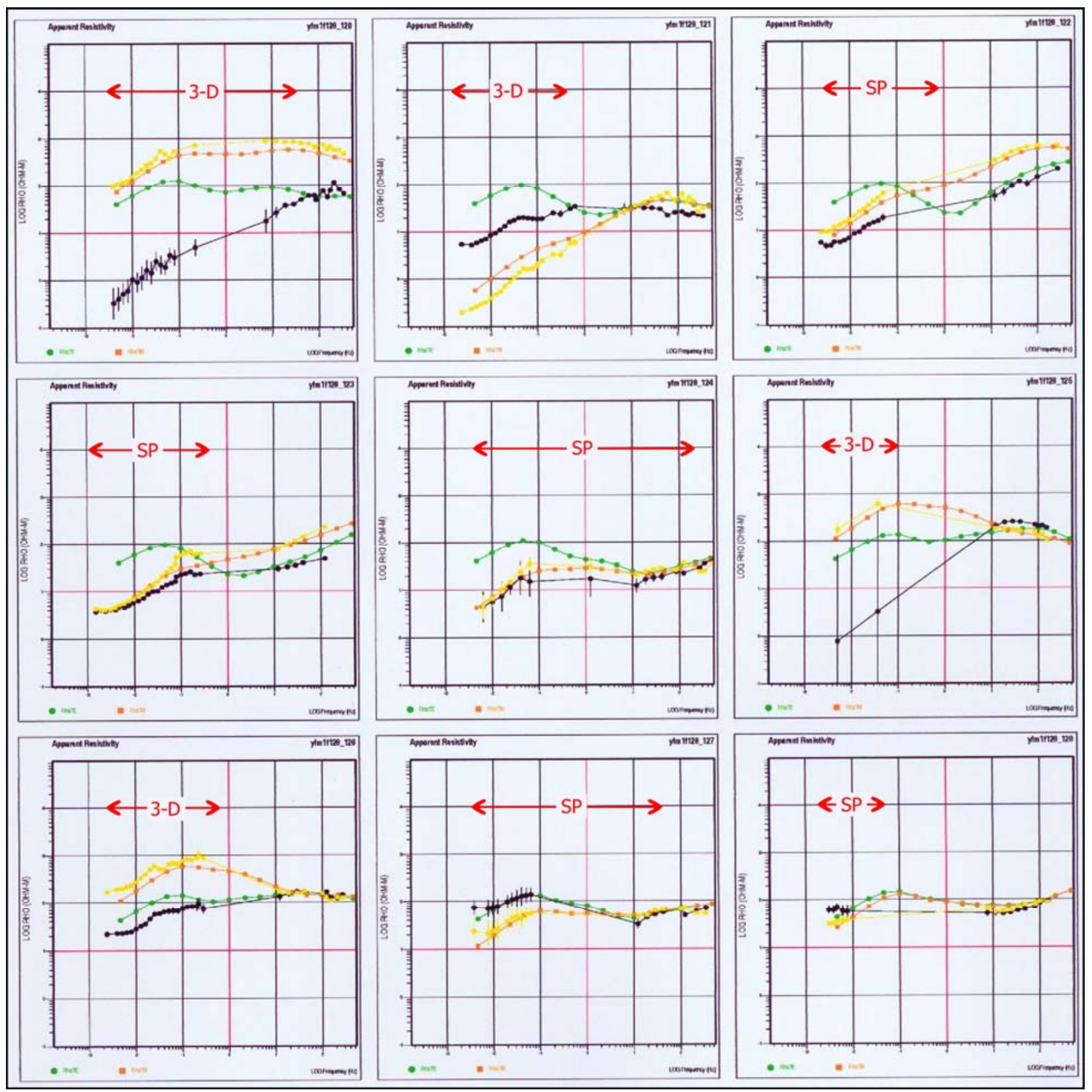

Figure A3. Profile 1, 2-D resistivity model 128 - observed (TE-black, TM-yellow) and calculated (TE-green, TM-orange) MT apparent resistivity sounding curves. 3-D label indicates threedimensional character of electromagnetic response. SP label indicates electrical resistivity structure is sub-parallel to the profile direction. 

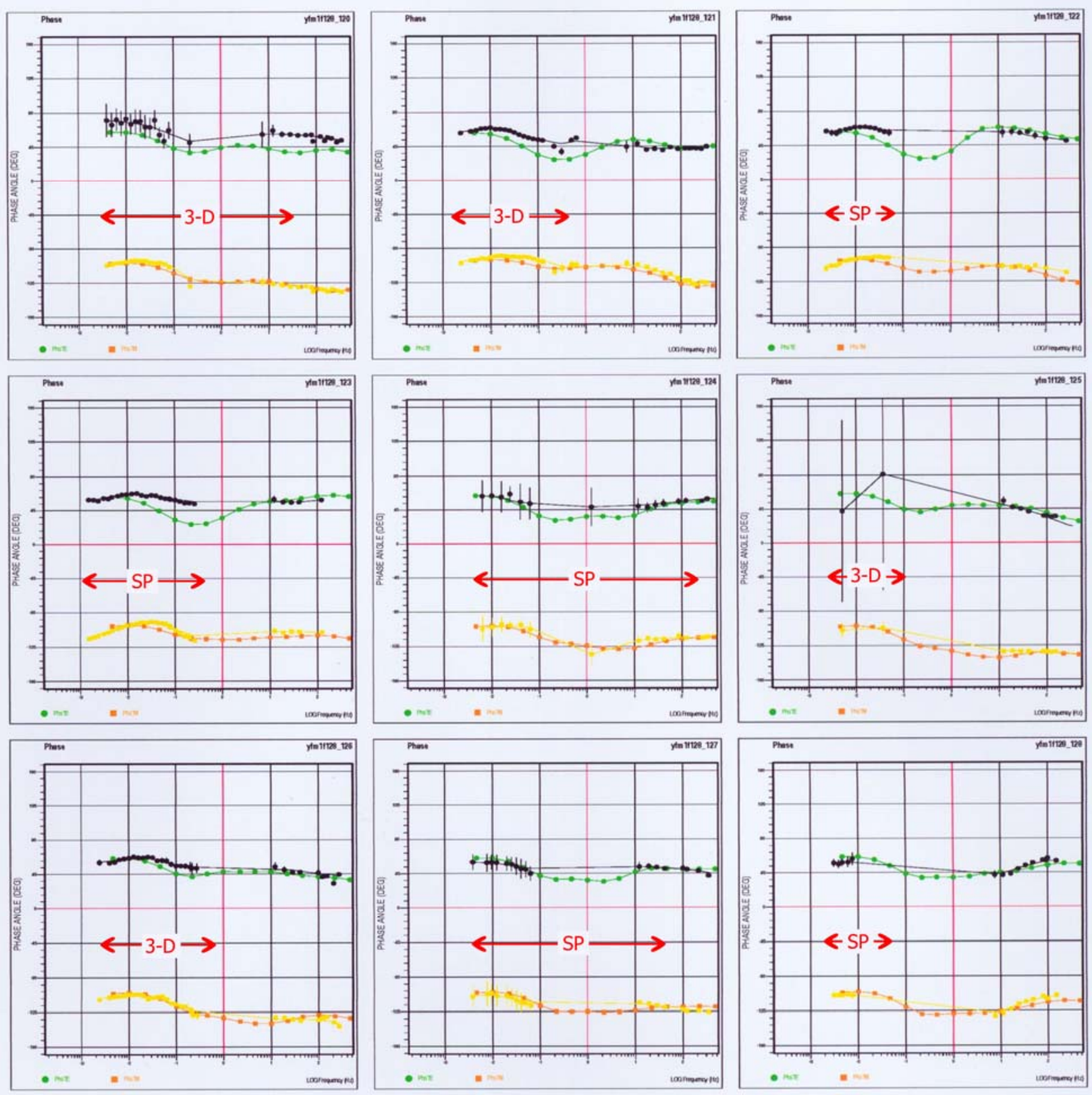

Figure A4. Profile 1, 2-D resistivity model 128 - observed (TE-black, TM-yellow) and calculated (TE-green, TM-orange) MT impedance phase curves. 3-D label indicates three-dimensional character of electromagnetic response. SP label indicates electrical resistivity structure is subparallel to the profile direction. 


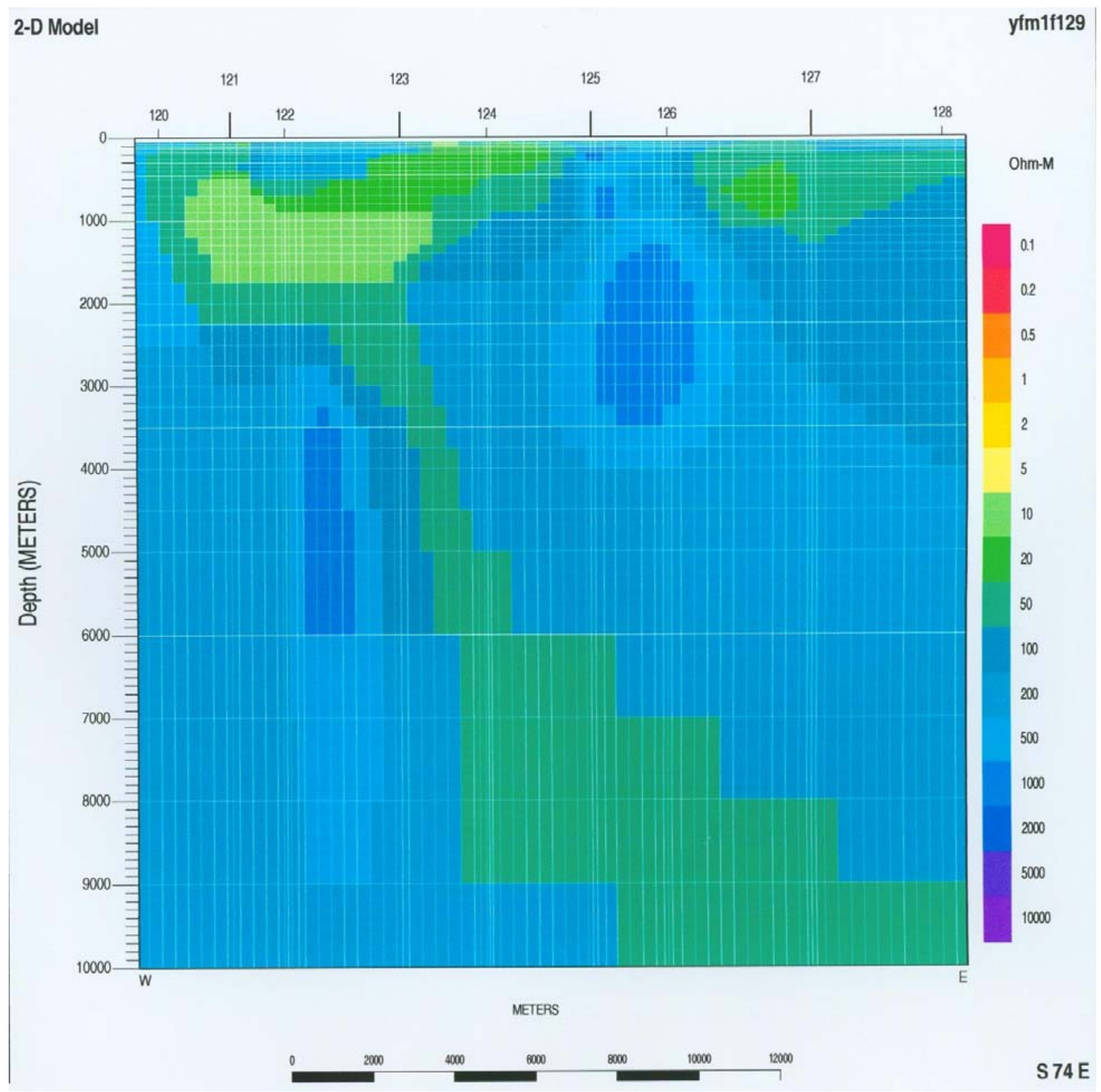

Figure A5. Profile 1, 2-D resistivity model 129 - depth section. 

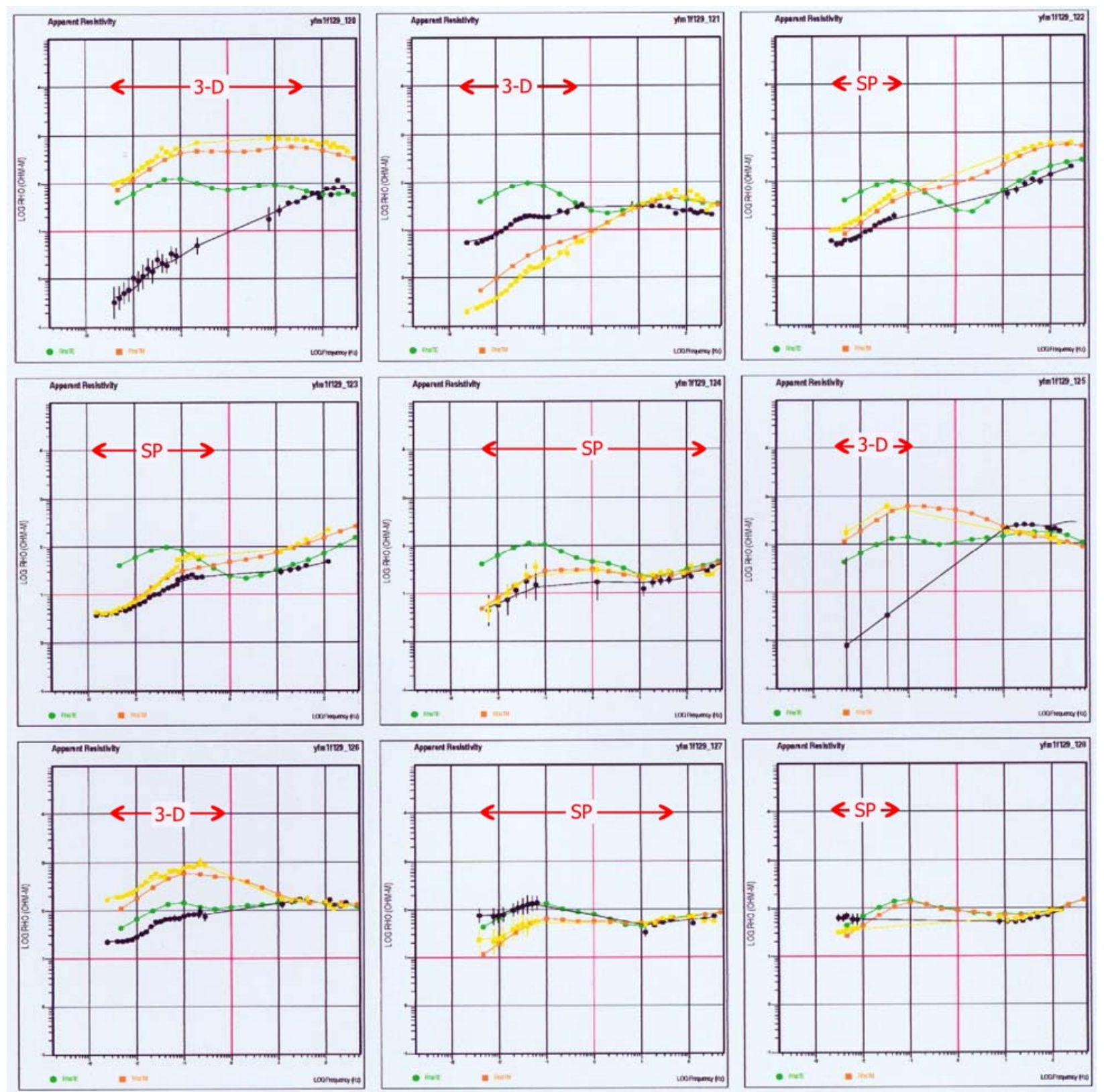

Figure A6. Profile 1, 2-D resistivity model 129 - observed (TE-black, TM-yellow) and calculated (TE-green, TM-orange) MT apparent resistivity sounding curves. 3-D label indicates threedimensional character of electromagnetic response. SP label indicates electrical resistivity structure is sub-parallel to the profile direction. 

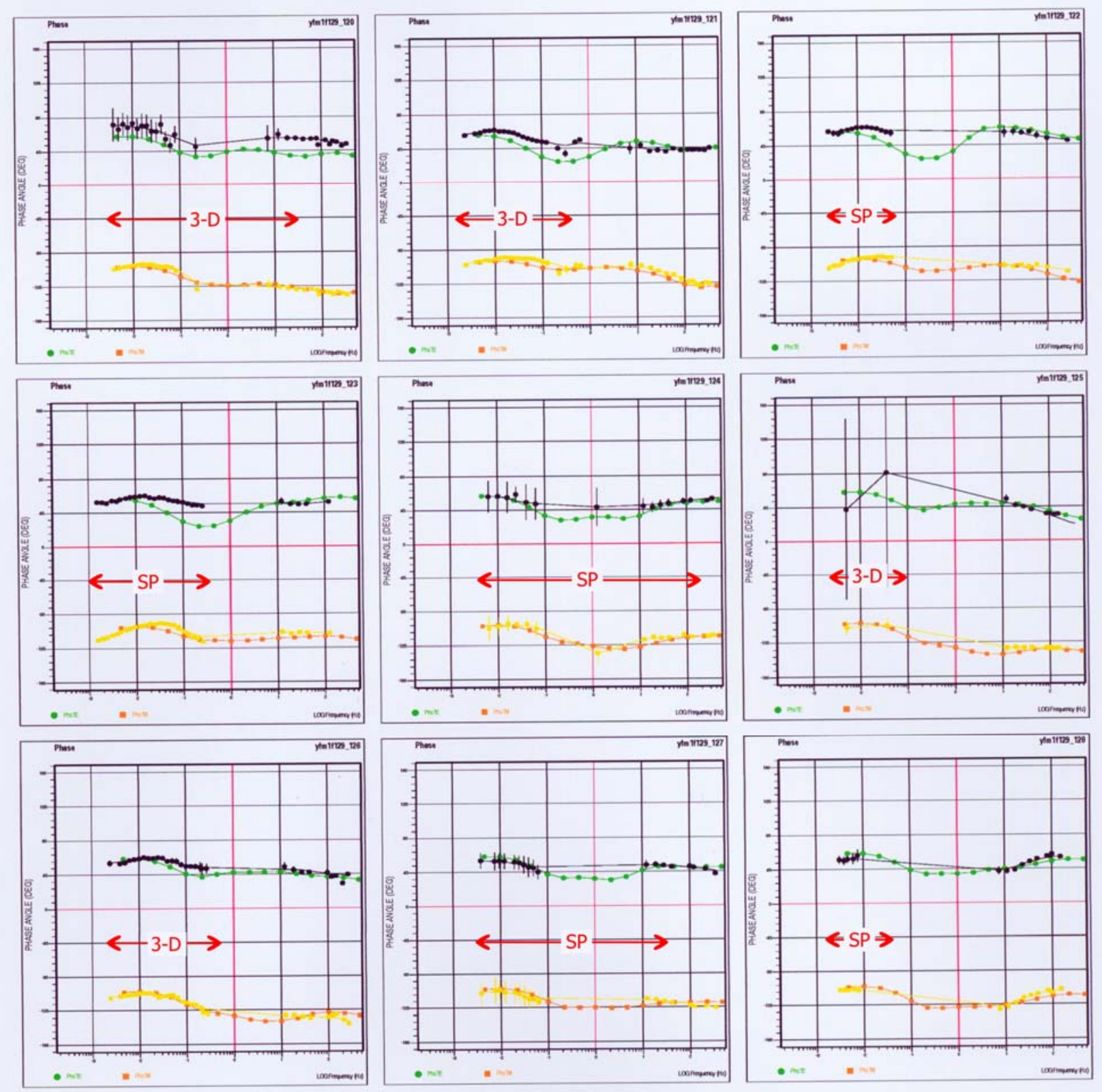

Figure A7. Profile 1, 2-D resistivity model 129 - observed (TE-black, TM-yellow) and calculated (TE-green, TM-orange) MT impedance phase curves. 3-D label indicates three-dimensional character of electromagnetic response. SP label indicates electrical resistivity structure is subparallel to the profile direction. 


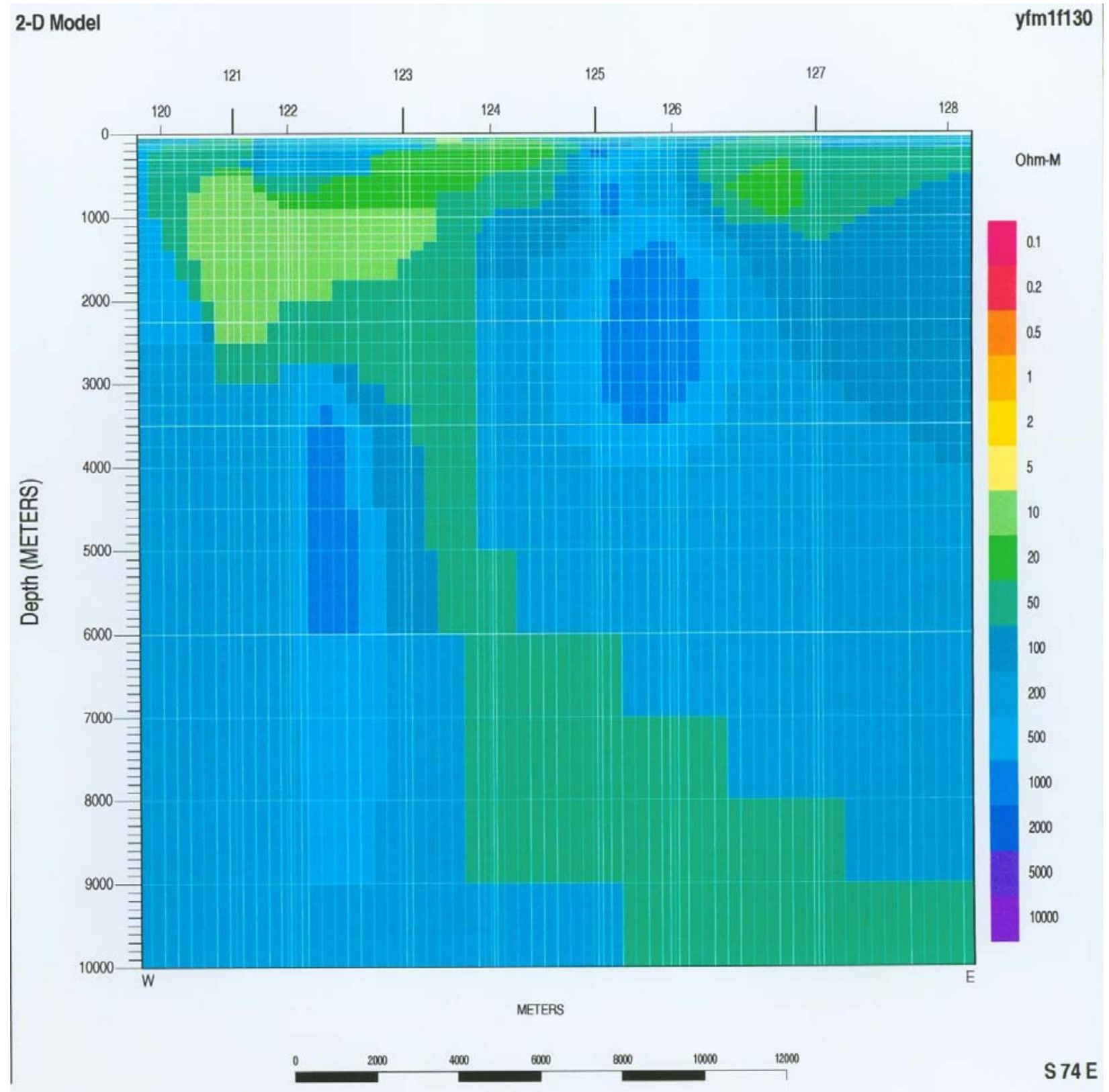

Figure A8. Profile 1, 2-D resistivity model 130 - depth section. 

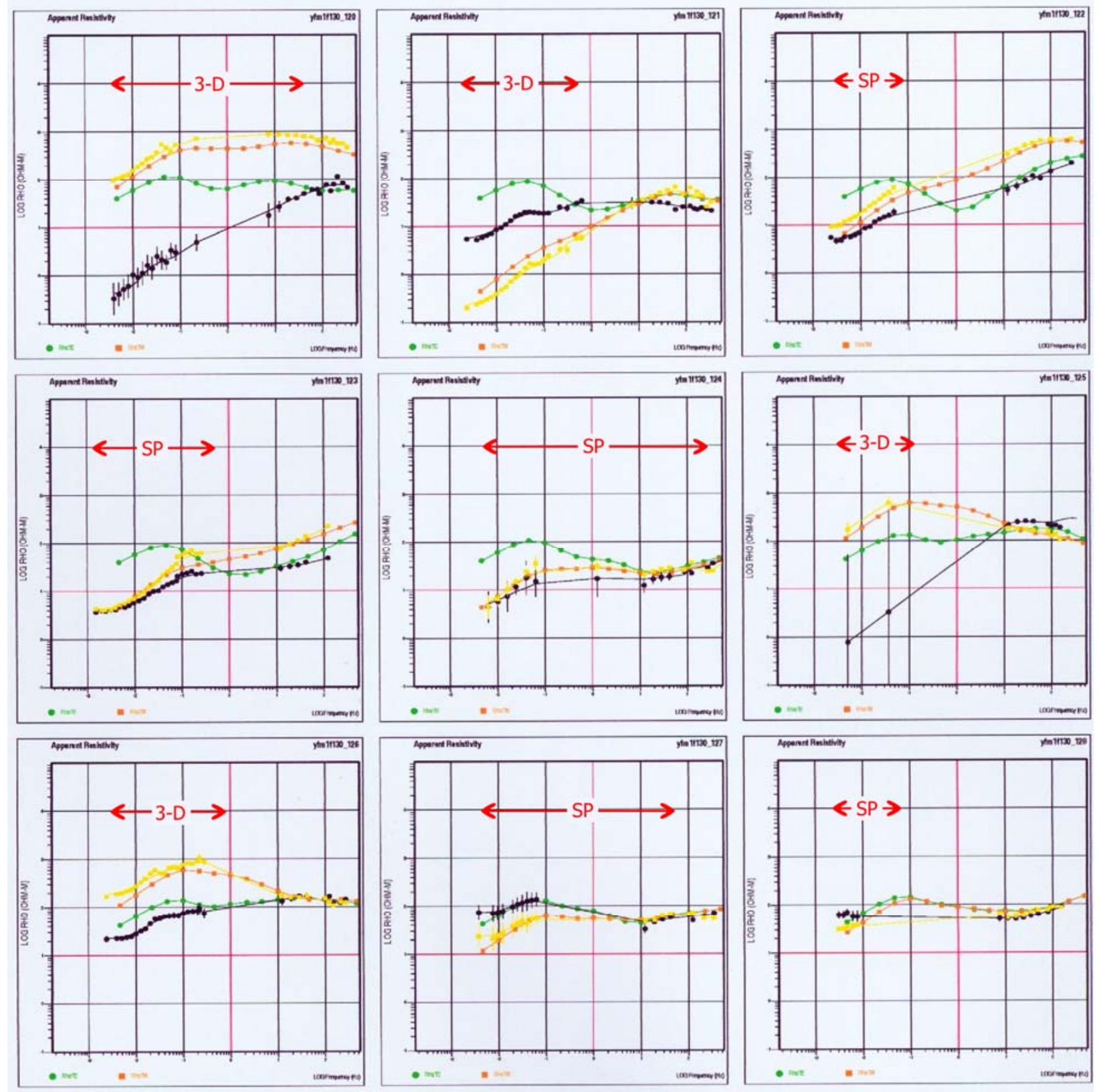

Figure A9. Profile 1, 2-D resistivity model 130 - observed (TE-black, TM-yellow) and calculated (TE-green, TM-orange) MT apparent resistivity sounding curves. 3-D label indicates threedimensional character of electromagnetic response. SP label indicates electrical resistivity structure is sub-parallel to the profile direction. 

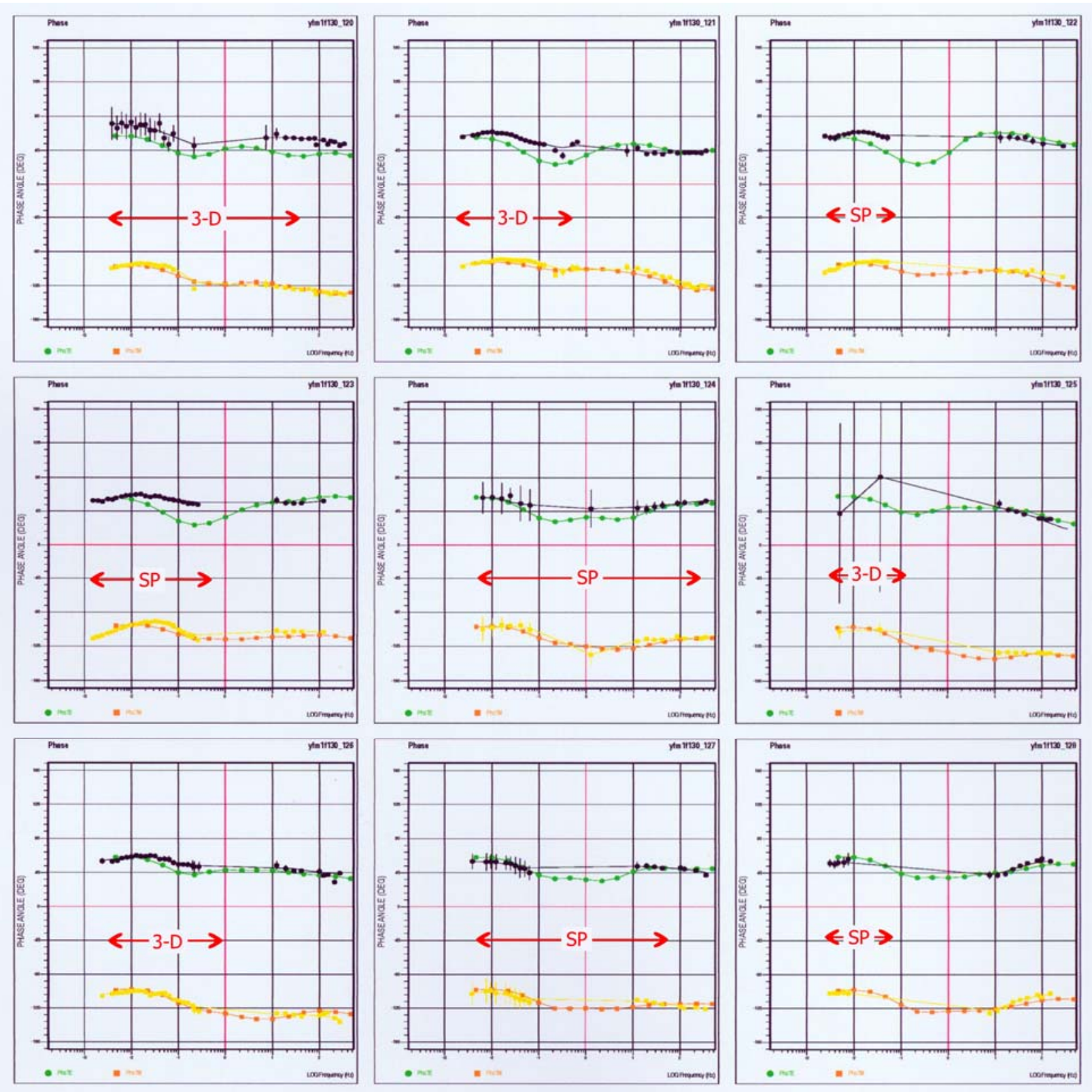

Figure A10. Profile 1, 2-D resistivity model 130 - observed (TE-black, TM-yellow) and calculated (TE-green, TM-orange) MT impedance phase curves. 3-D label indicates three-dimensional character of electromagnetic response. SP label indicates electrical resistivity structure is subparallel to the profile direction. 


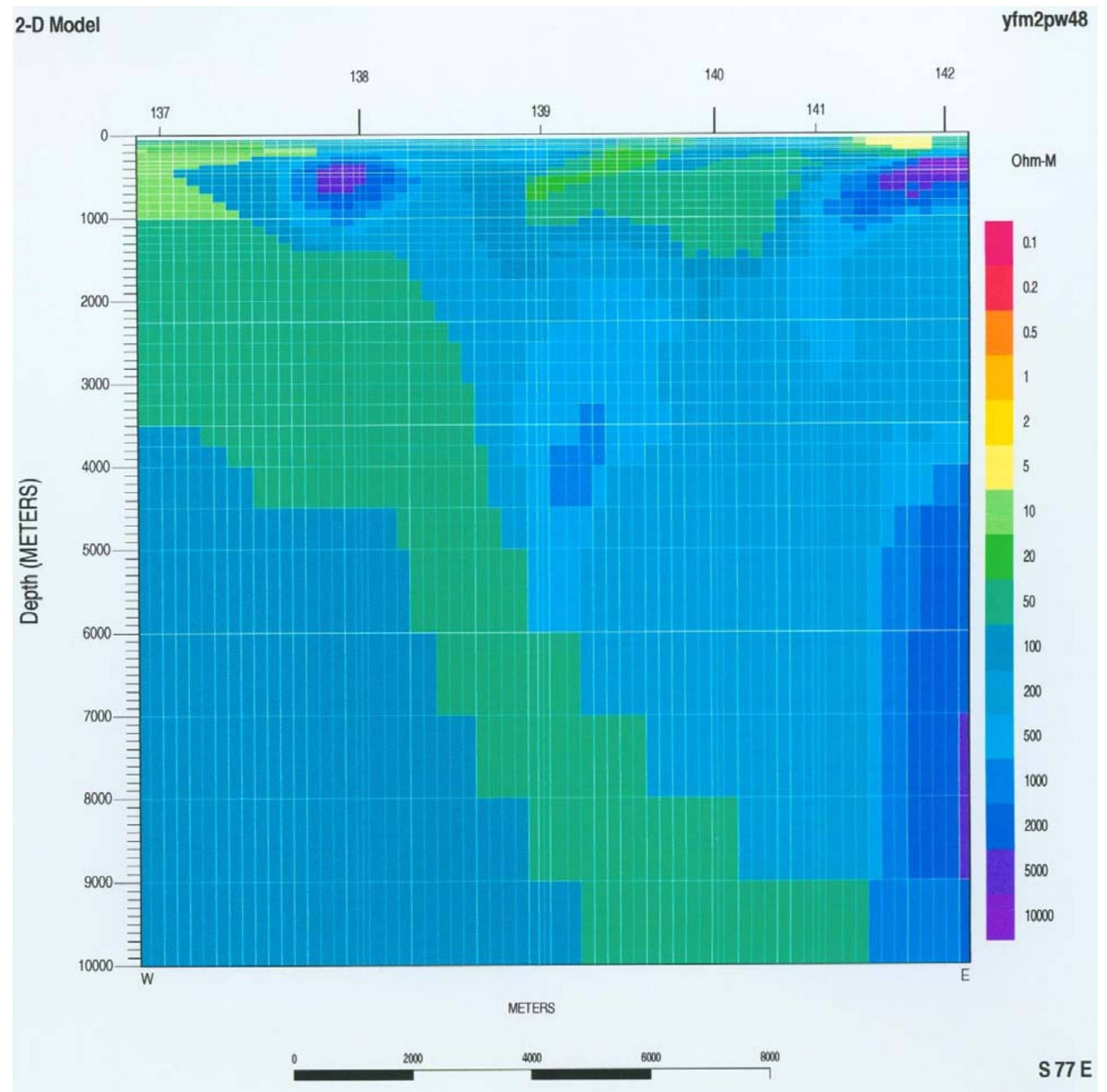

Figure A11. Profile 2, 2-D resistivity model 48 - depth section. 

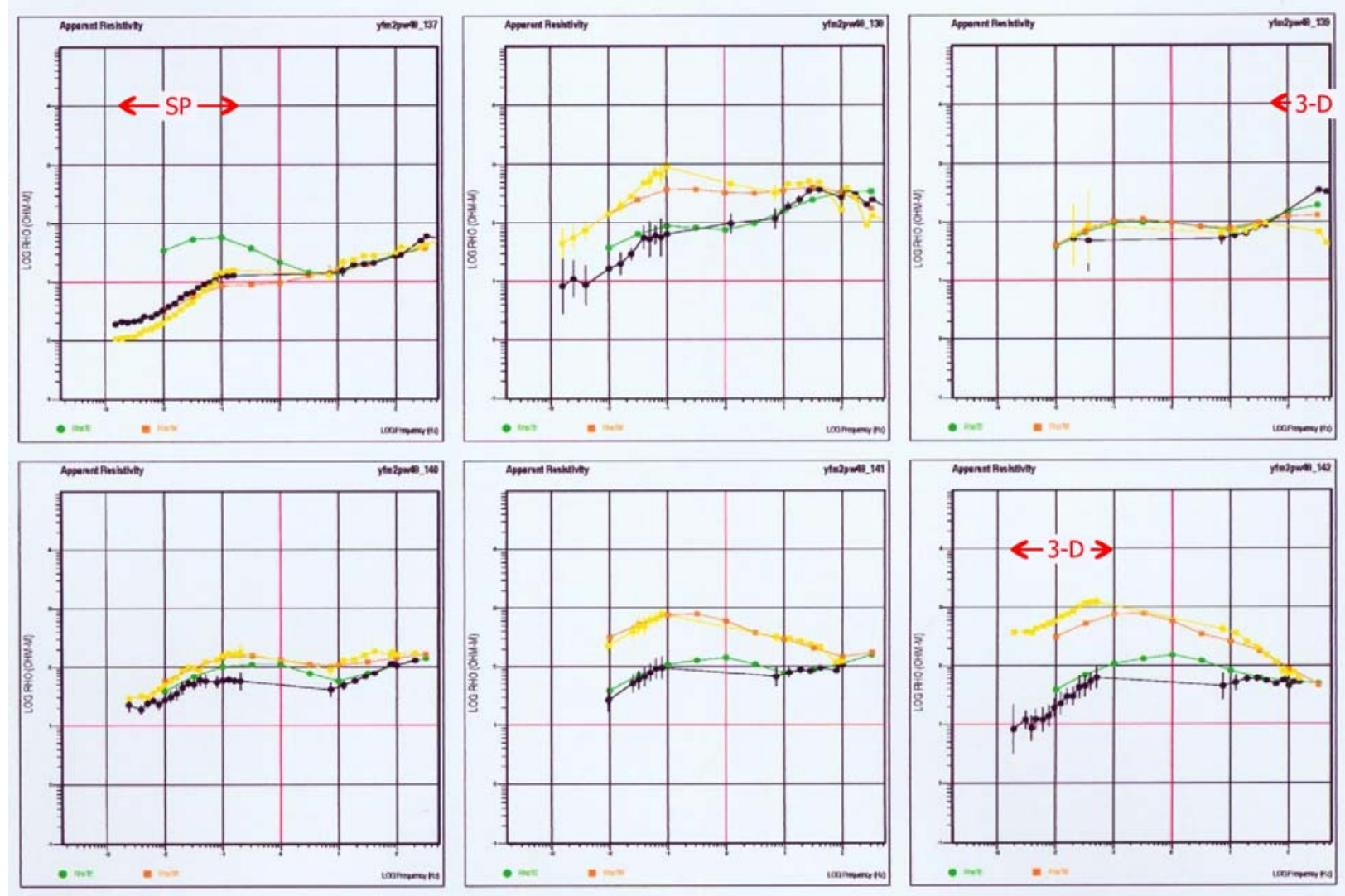

Figure A12. Profile 2, 2-D resistivity model 48 - observed (TE-black, TM-yellow) and calculated (TE-green, TM-orange) MT apparent resistivity sounding curves. 3-D label indicates threedimensional character of electromagnetic response. SP label indicates electrical resistivity structure is sub-parallel to the profile direction. 

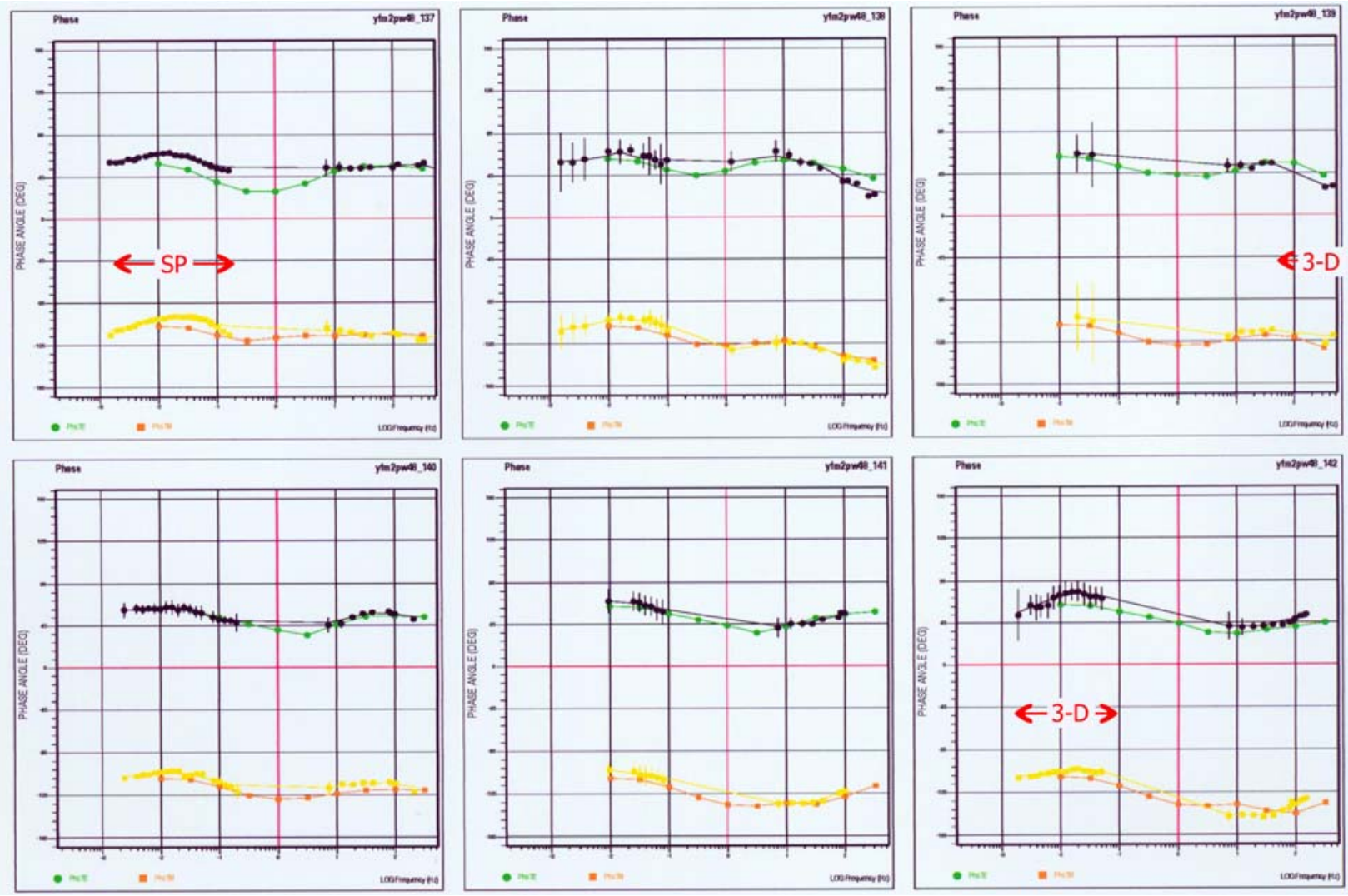

Figure A13. Profile 2, 2-D resistivity model 48 - observed (TE-black, TM-yellow) and calculated (TE-green, TM-orange) MT impedance phase curves. 3-D label indicates three-dimensional character of electromagnetic response. SP label indicates electrical resistivity structure is subparallel to the profile direction. 


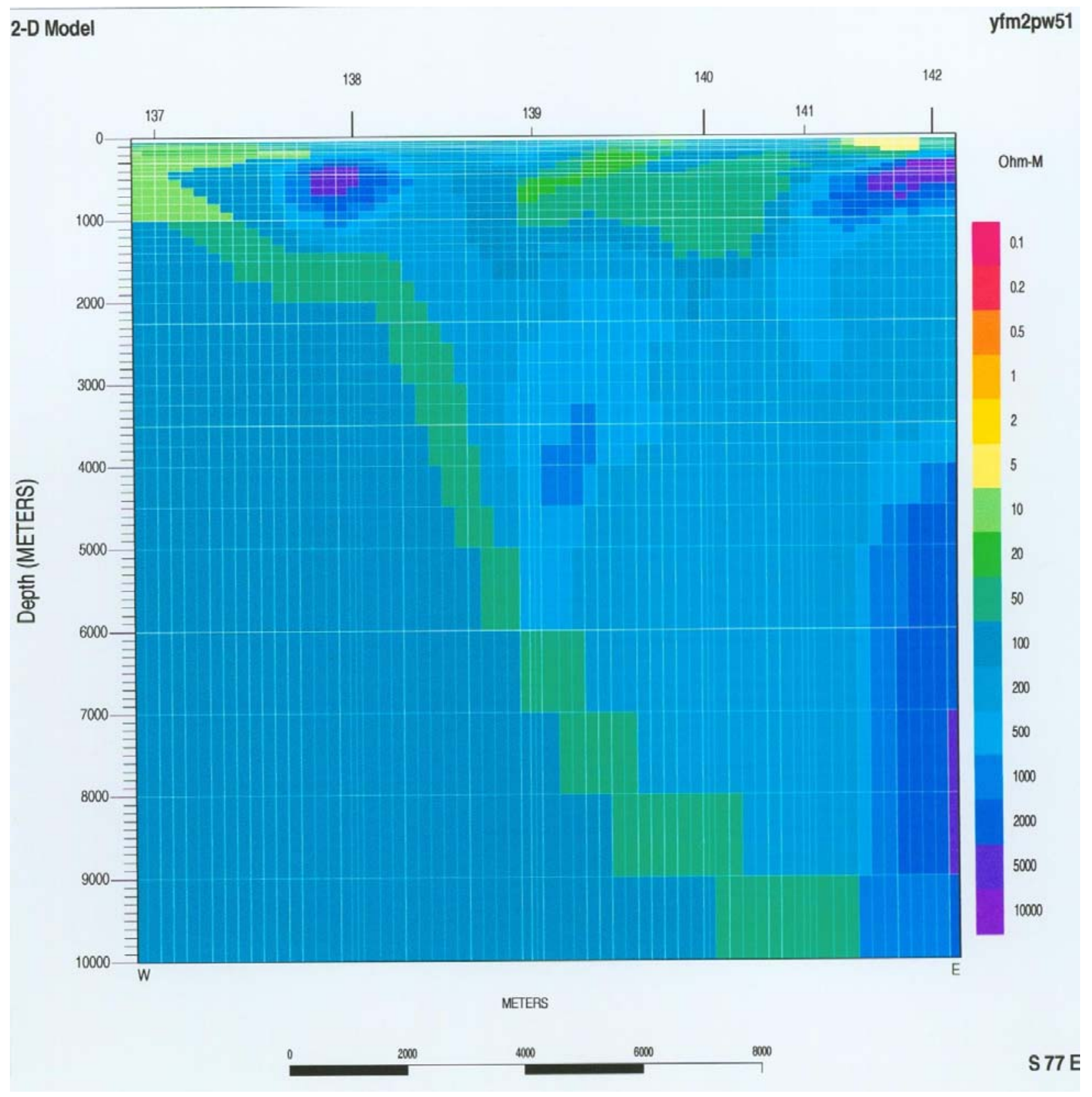

Figure A14. Profile 2, 2-D resistivity model 51 - depth section. 

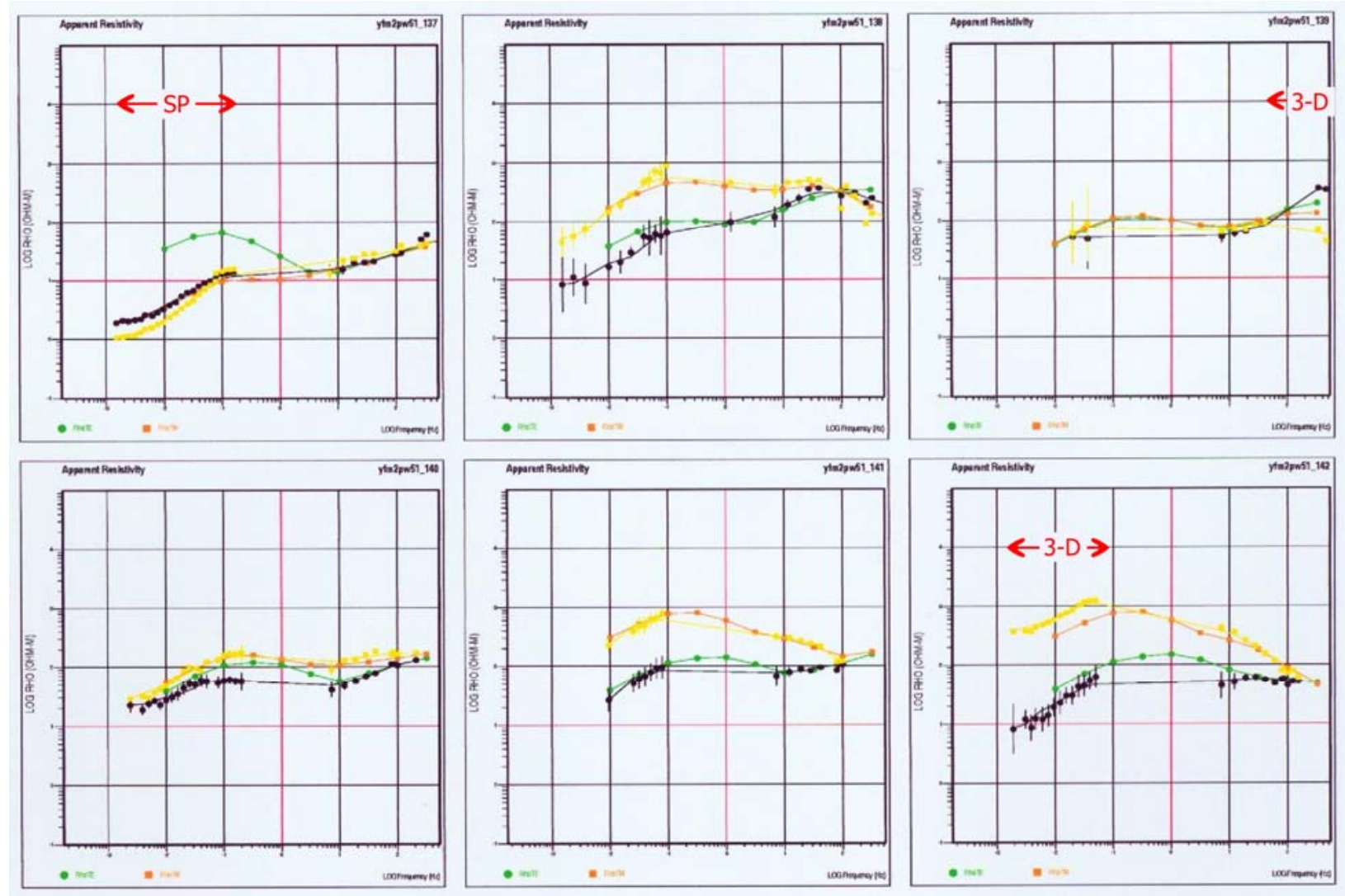

Figure A15. Profile 2, 2-D resistivity model 51 - observed (TE-black, TM-yellow) and calculated (TE-green, TM-orange) MT apparent resistivity sounding curves. 3-D label indicates threedimensional character of electromagnetic response. SP label indicates electrical resistivity structure is sub-parallel to the profile direction. 

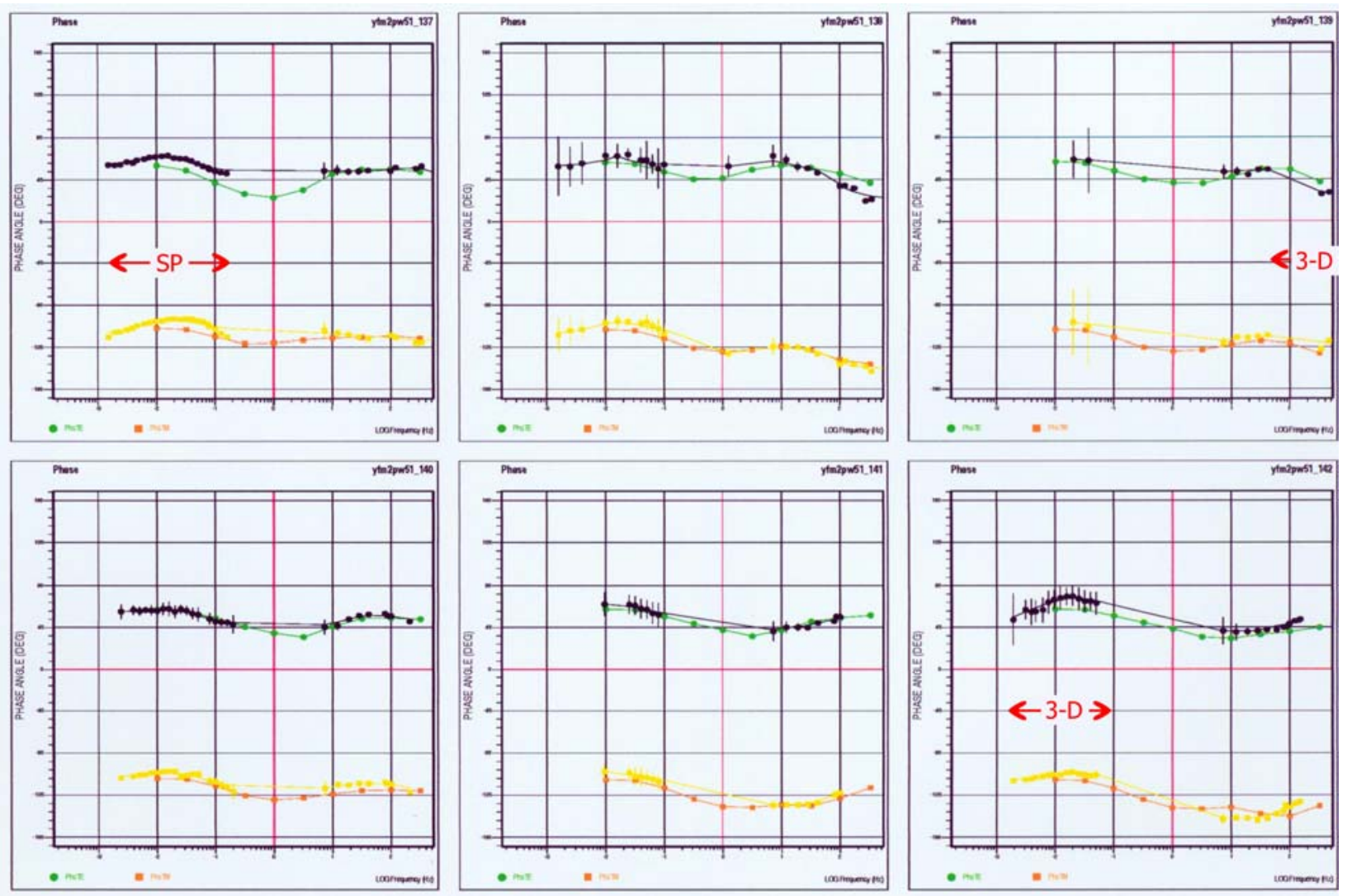

Figure A16. Profile 2, 2-D resistivity model 51 - observed (TE-black, TM-yellow) and calculated (TE-green, TM-orange) MT impedance phase curves. 3-D label indicates three-dimensional character of electromagnetic response. SP label indicates electrical resistivity structure is subparallel to the profile direction. 


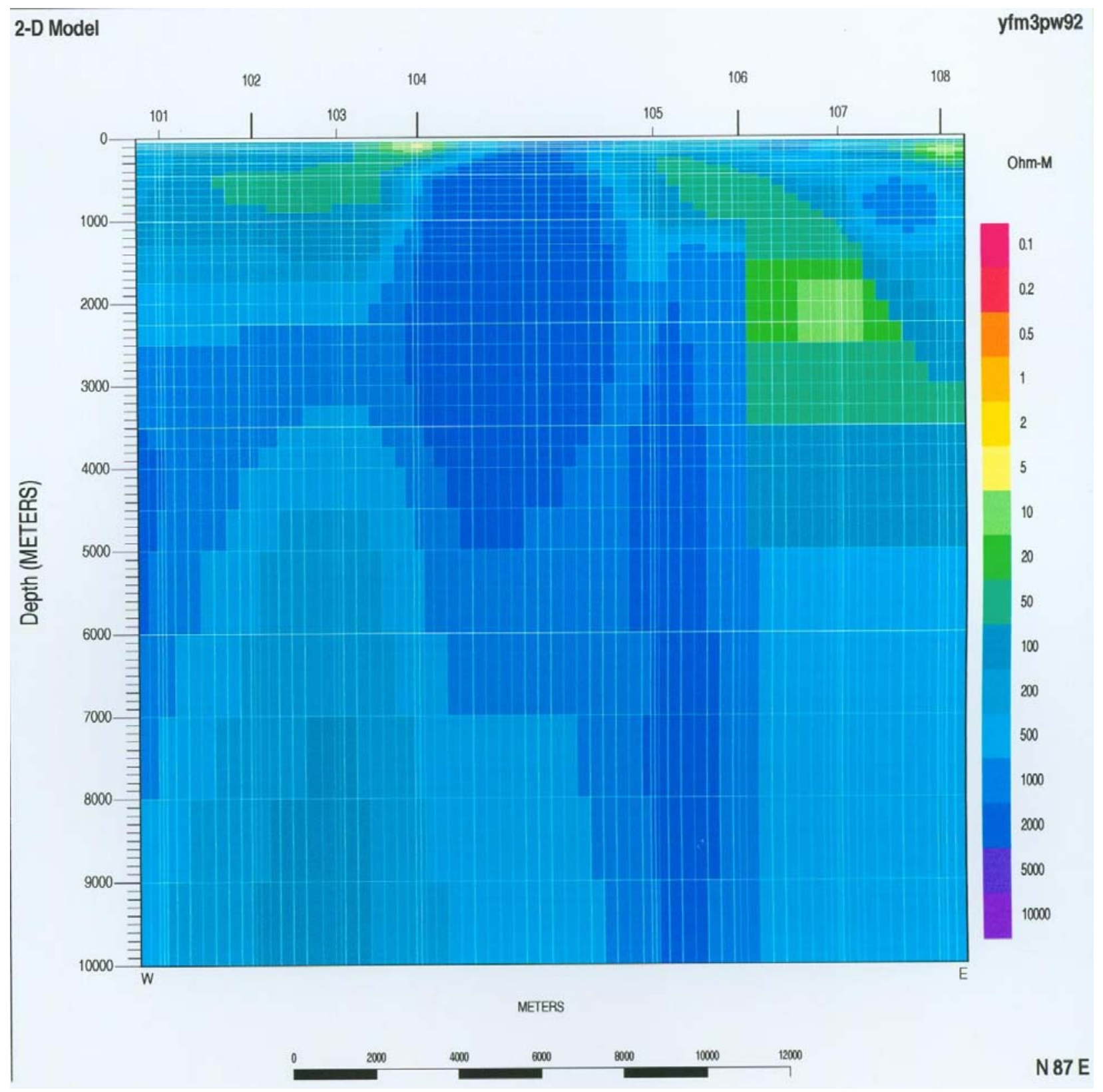

Figure A17. Profile 3, 2-D resistivity model 92 - depth section. 

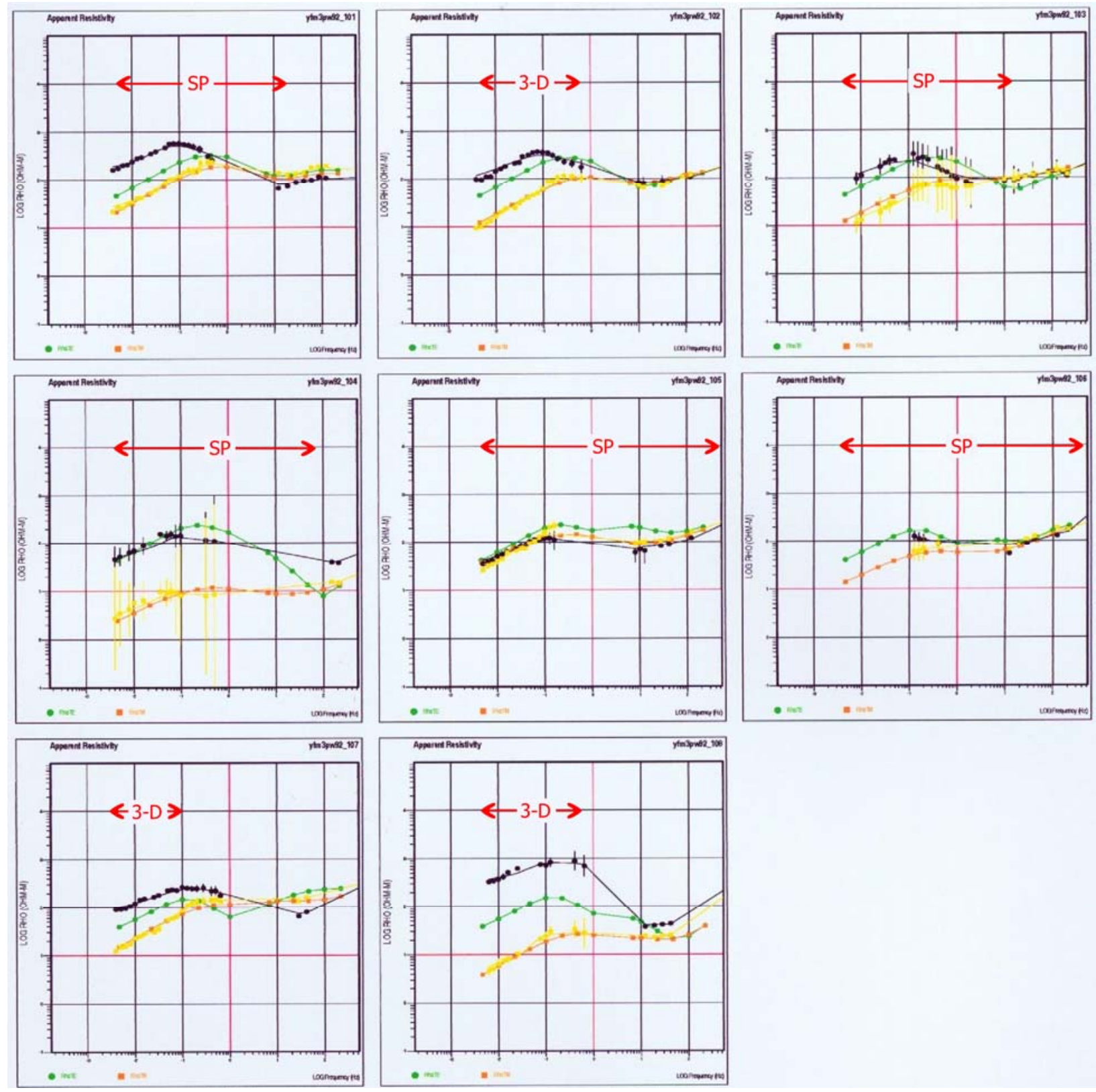

Figure A18. Profile 3, 2-D resistivity model 92 - observed (TE-black, TM-yellow) and calculated (TE-green, TM-orange) MT apparent resistivity sounding curves. 3-D label indicates threedimensional character of electromagnetic response. SP label indicates electrical resistivity structure is sub-parallel to the profile direction. 

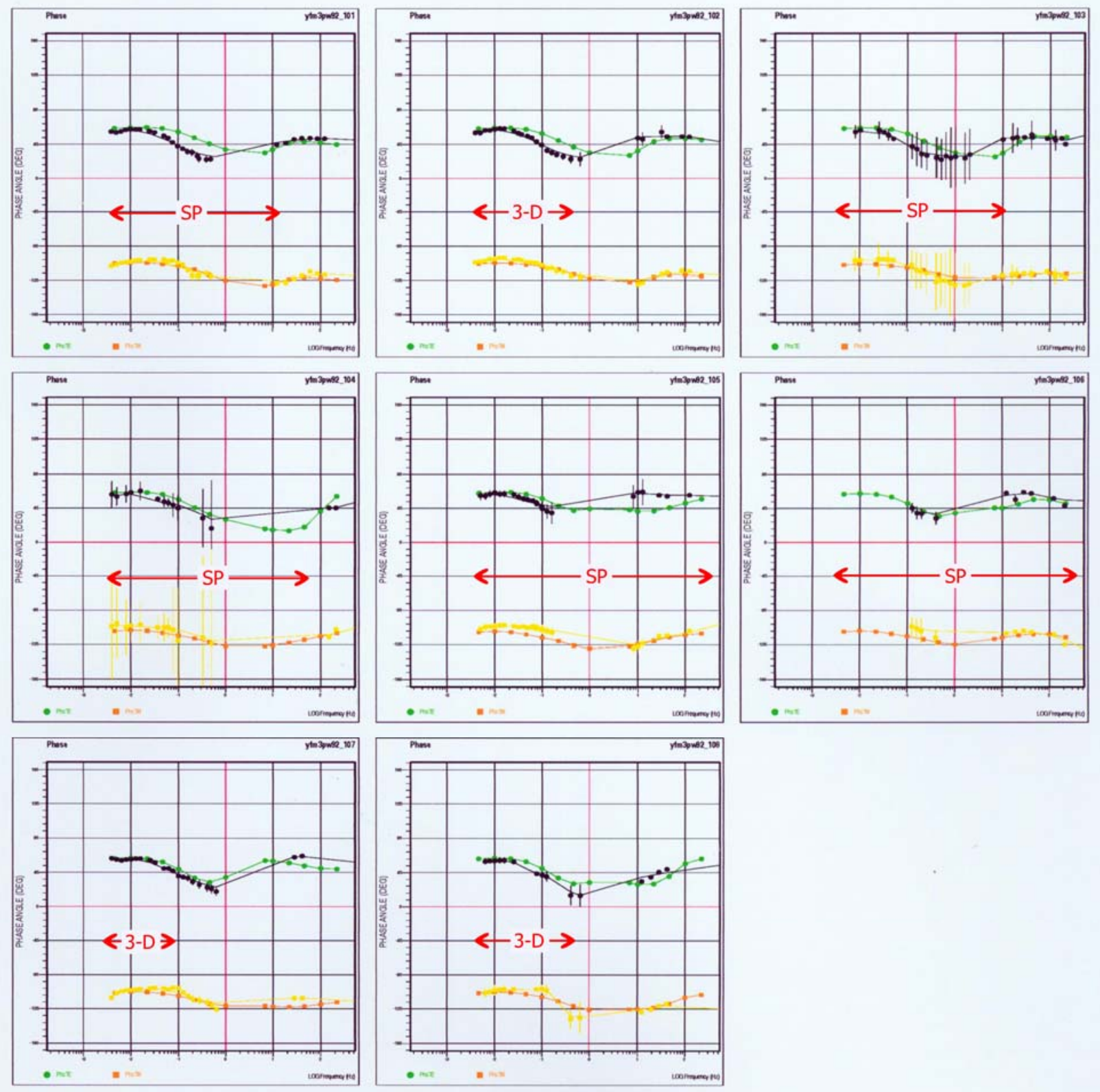

Figure A19. Profile 3, 2-D resistivity model 92 - observed (TE-black, TM-yellow) and calculated (TE-green, TM-orange) MT impedance phase curves. 3-D label indicates three-dimensional character of electromagnetic response. SP label indicates electrical resistivity structure is subparallel to the profile direction. 


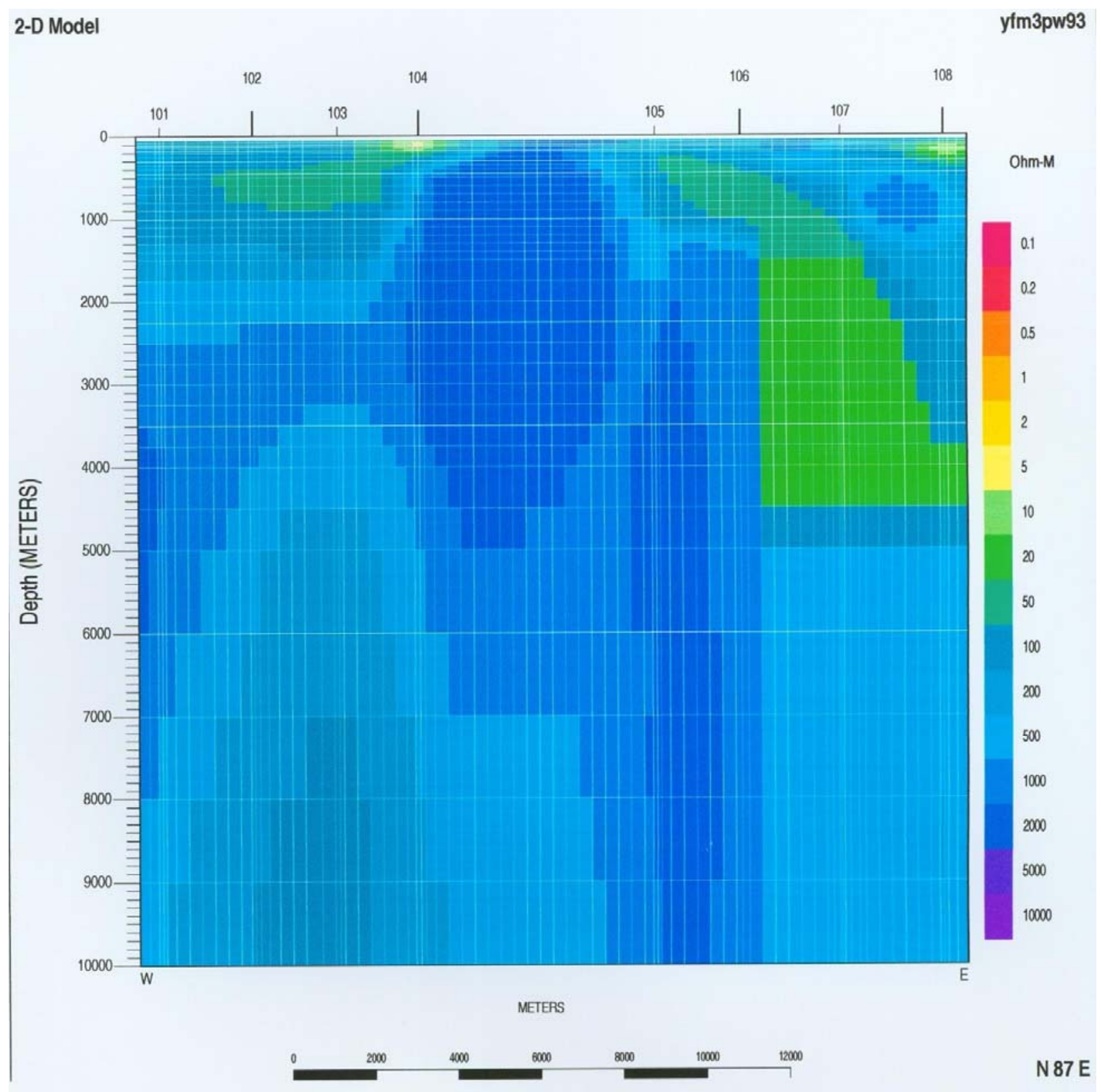

Figure A20. Profile 3, 2-D resistivity model 93 - depth section. 

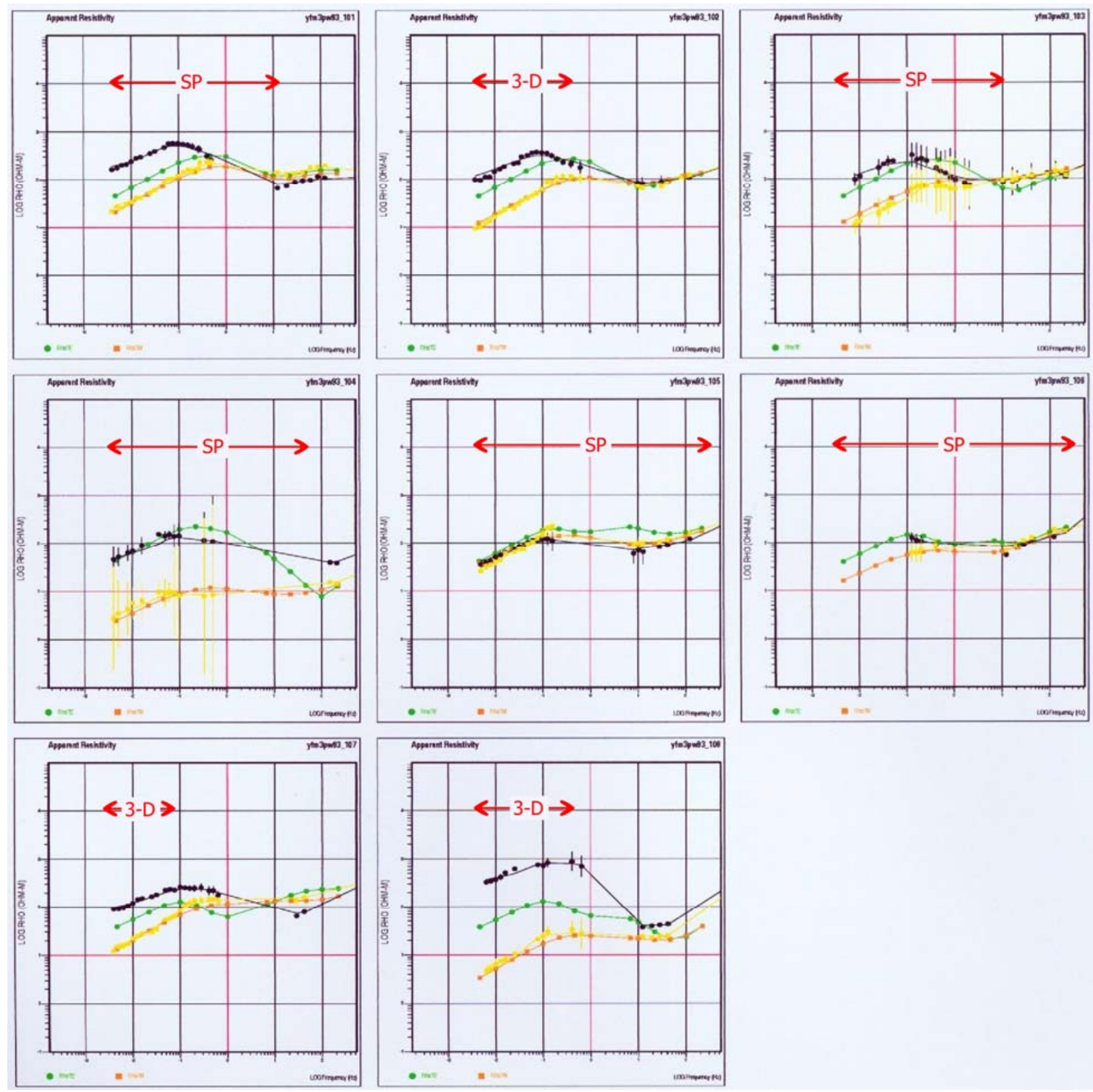

Figure A21. Profile 3, 2-D resistivity model 93 - observed (TE-black, TM-yellow) and calculated (TE-green, TM-orange) MT apparent resistivity sounding curves. 3-D label indicates threedimensional character of electromagnetic response. SP label indicates electrical resistivity structure is sub-parallel to the profile direction. 

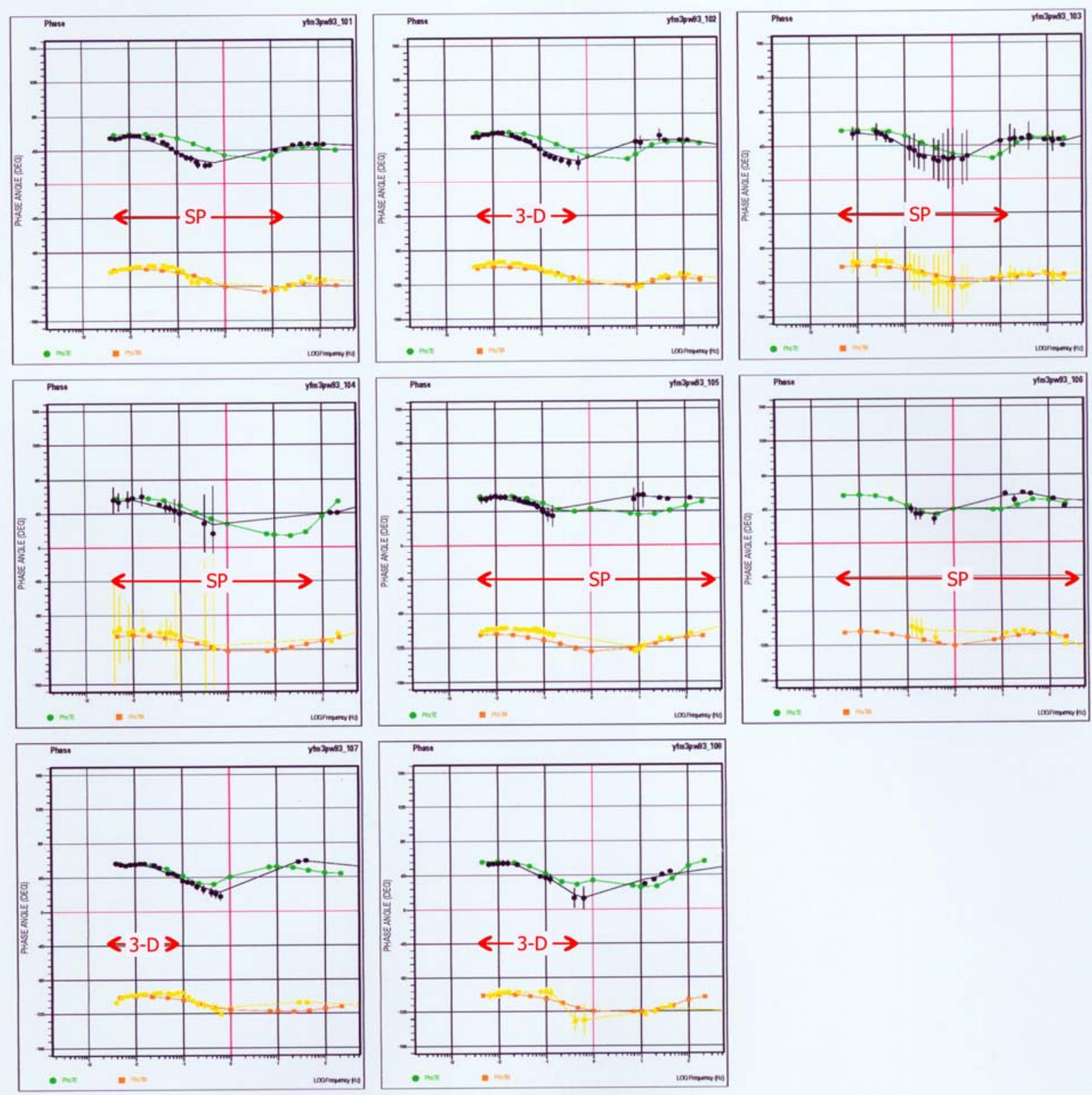

Figure A22. Profile 3, 2-D resistivity model 93 - observed (TE-black, TM-yellow) and calculated (TE-green, TM-orange) MT impedance phase curves. 3-D label indicates three-dimensional character of electromagnetic response. SP label indicates electrical resistivity structure is subparallel to the profile direction. 


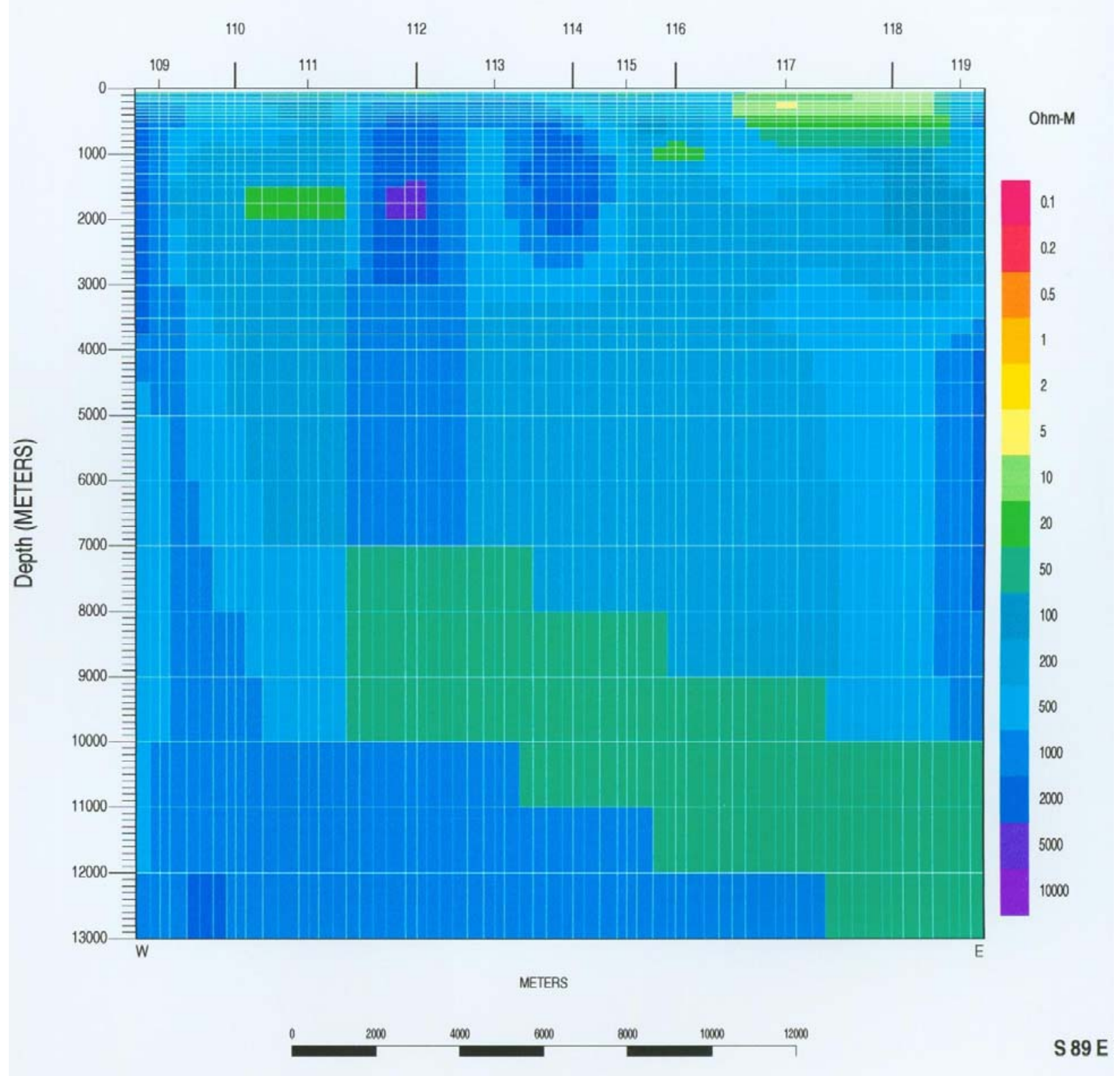

Figure A23. Profile 4, 2-D resistivity model 53 - depth section. 

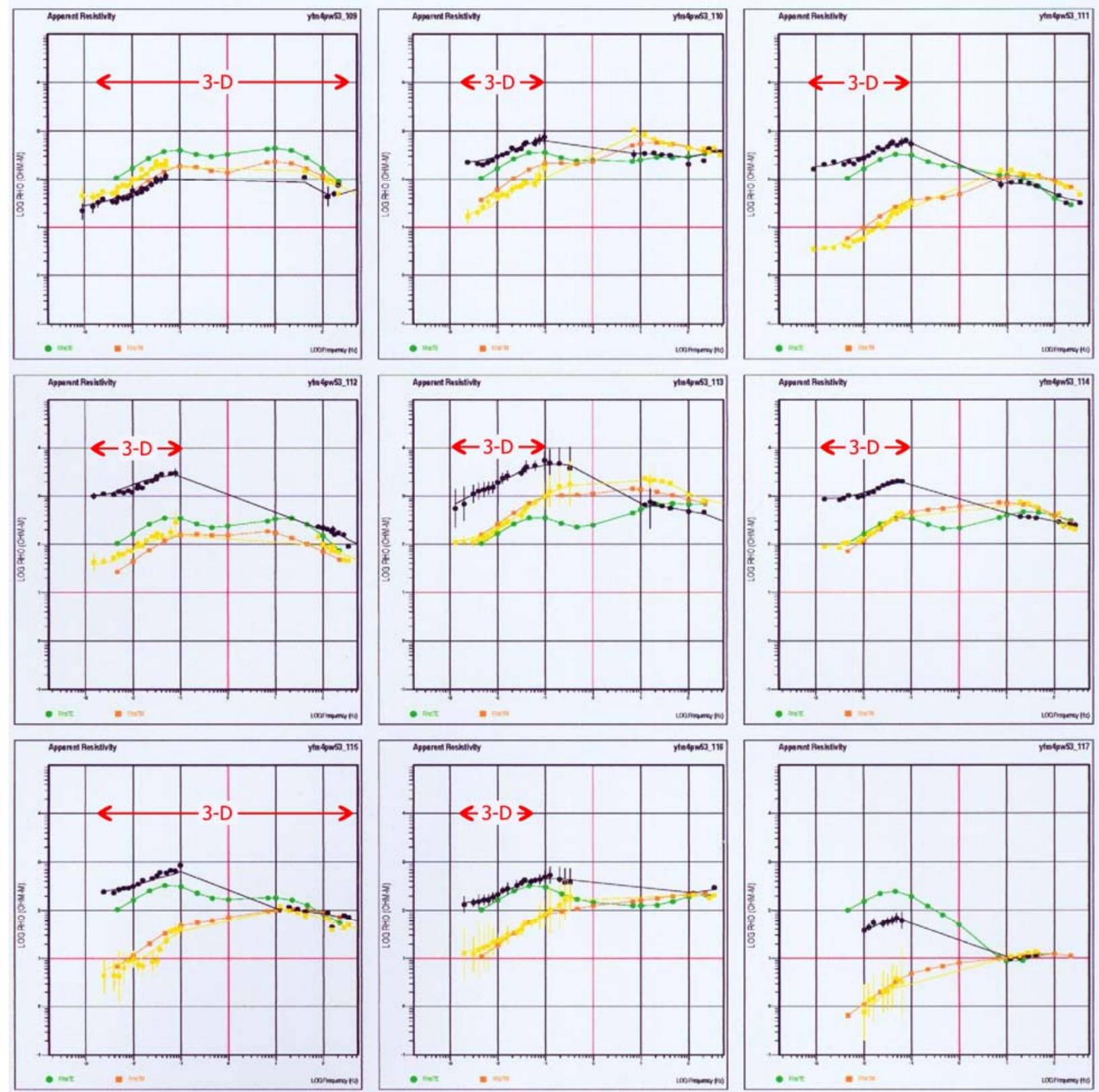

Figure A24a. Profile 4, 2-D resistivity model 53 - observed (TE-black, TM-yellow) and calculated (TE-green, TM-orange) MT apparent resistivity sounding curves. 3-D label indicates threedimensional character of electromagnetic response. SP label indicates electrical resistivity structure is sub-parallel to the profile direction. 

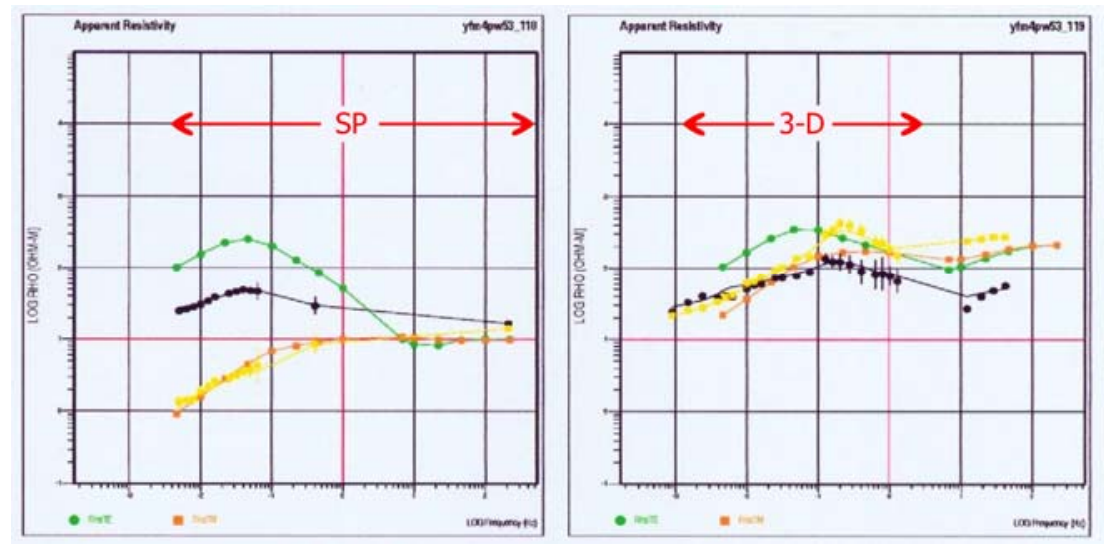

Figure A24b. Profile 4, 2-D resistivity model 53 - observed (TE-black, TM-yellow) and calculated (TE-green, TM-orange) MT apparent resistivity sounding curves. 3-D label indicates threedimensional character of electromagnetic response. SP label indicates electrical resistivity structure is sub-parallel to the profile direction. 

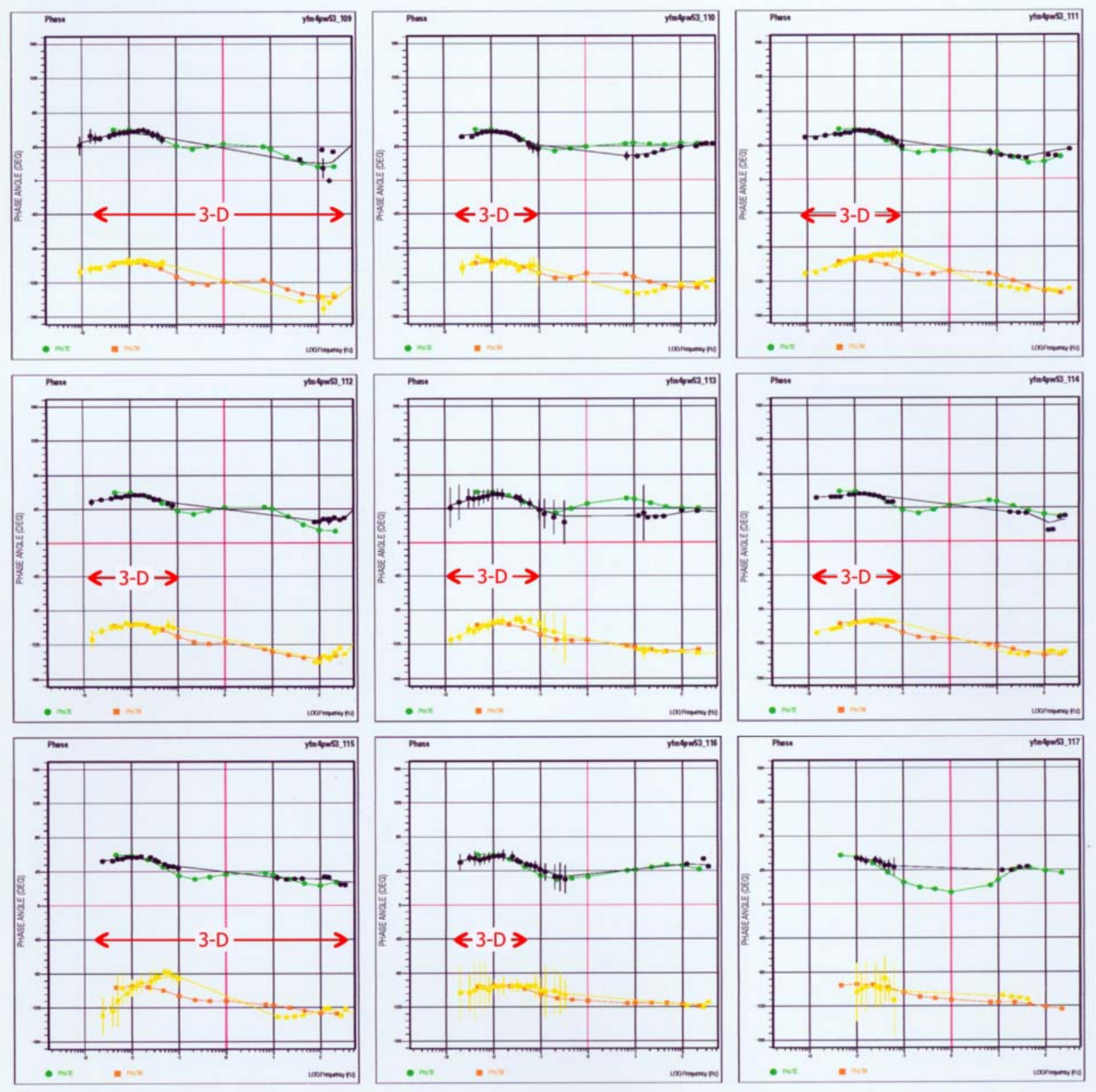

Figure A25a. Profile 4, 2-D resistivity model 53 - observed (TE-black, TM-yellow) and calculated (TE-green, TM-orange) MT impedance phase curves. 3-D label indicates three-dimensional character of electromagnetic response. SP label indicates electrical resistivity structure is subparallel to the profile direction. 

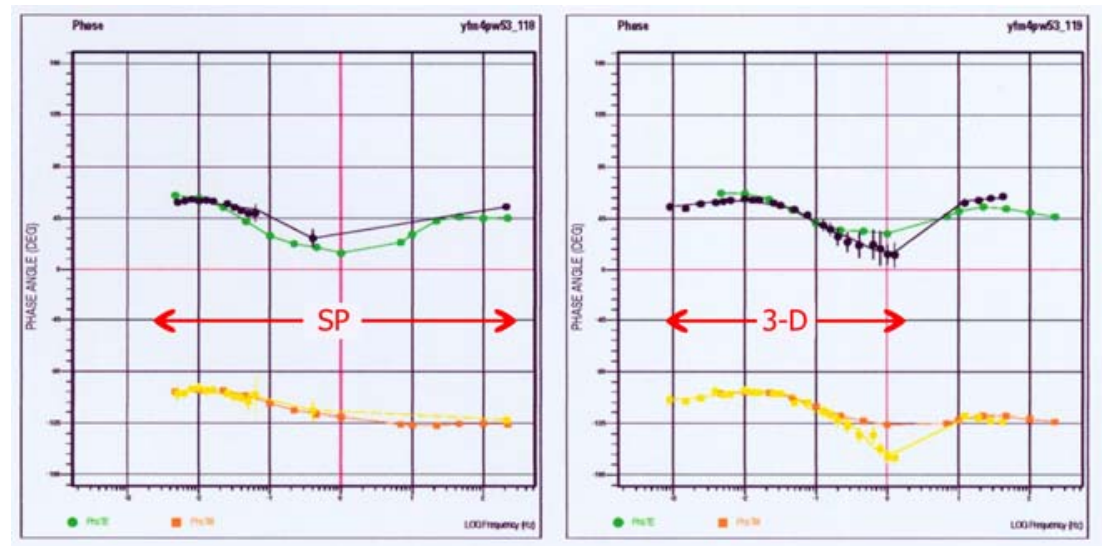

Figure A25b. Profile 4, 2-D resistivity model 53 - observed (TE-black, TM-yellow) and calculated (TE-green, TM-orange) MT impedance phase curves. 3-D label indicates three-dimensional character of electromagnetic response. SP label indicates electrical resistivity structure is subparallel to the profile direction. 


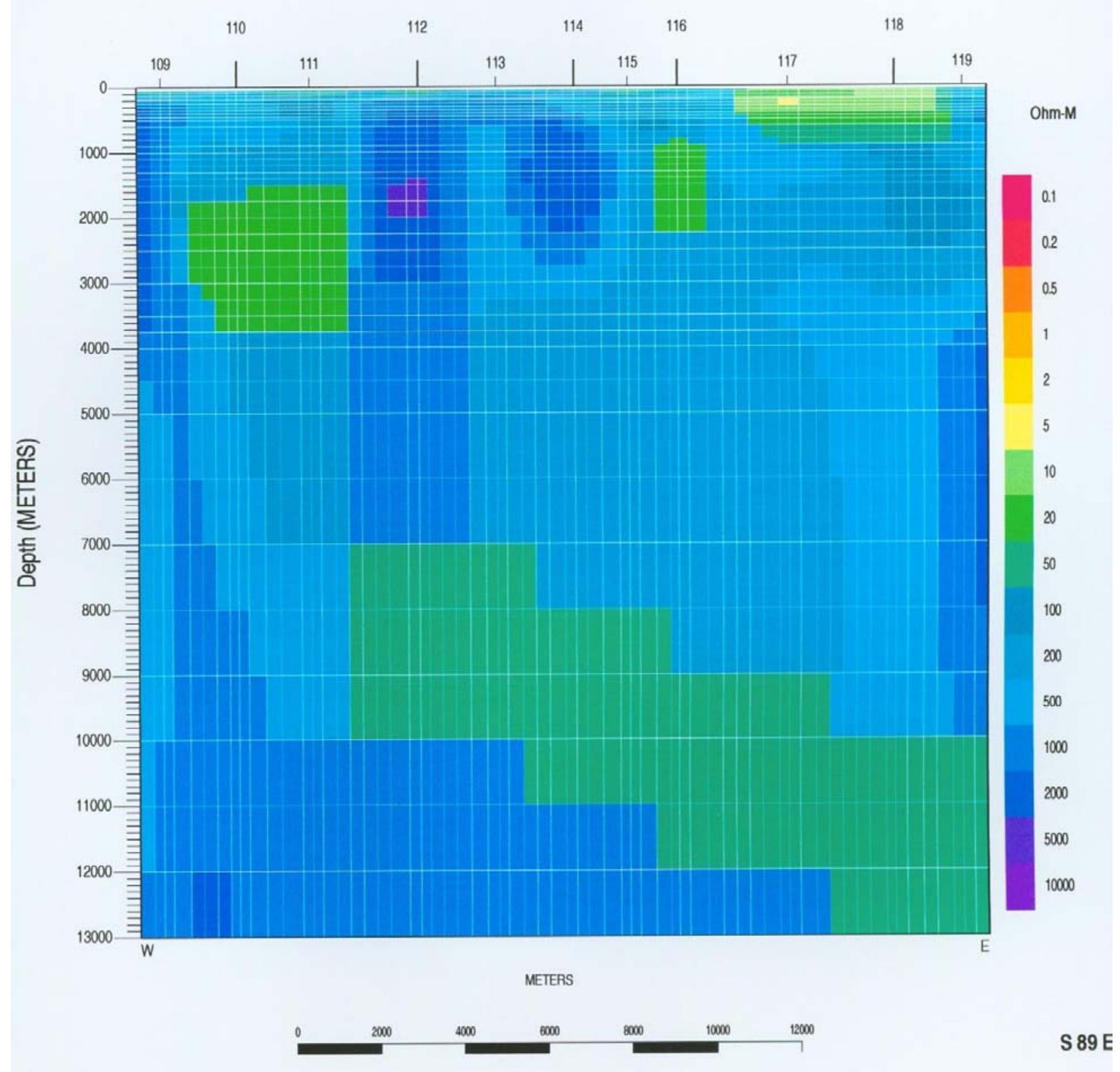

Figure A26. Profile 4, 2-D resistivity model 60 - depth section. 

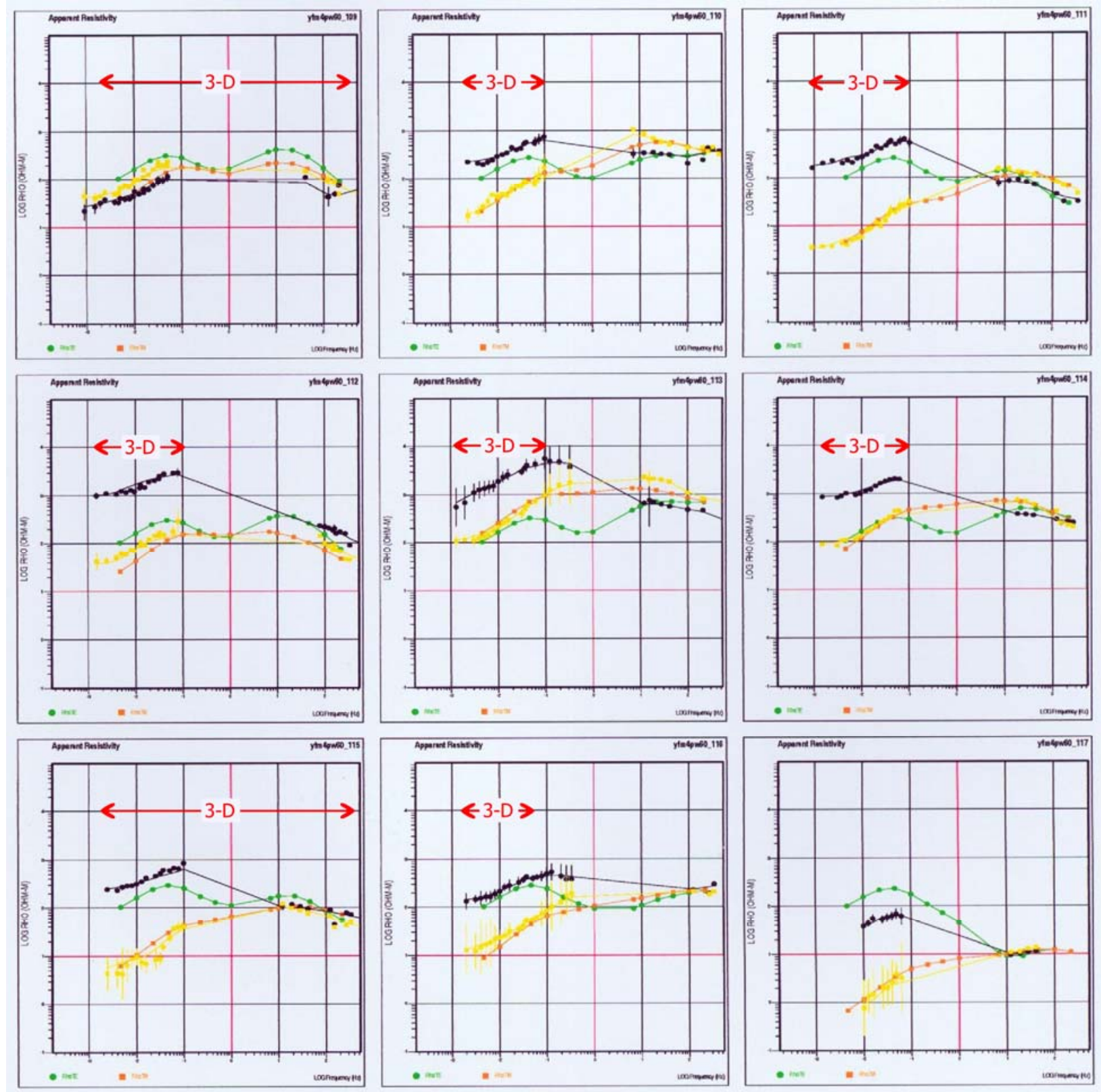

Figure A27a. Profile 4, 2-D resistivity model 60 - observed (TE-black, TM-yellow) and calculated (TE-green, TM-orange) MT apparent resistivity sounding curves. 3-D label indicates threedimensional character of electromagnetic response. SP label indicates electrical resistivity structure is sub-parallel to the profile direction. 

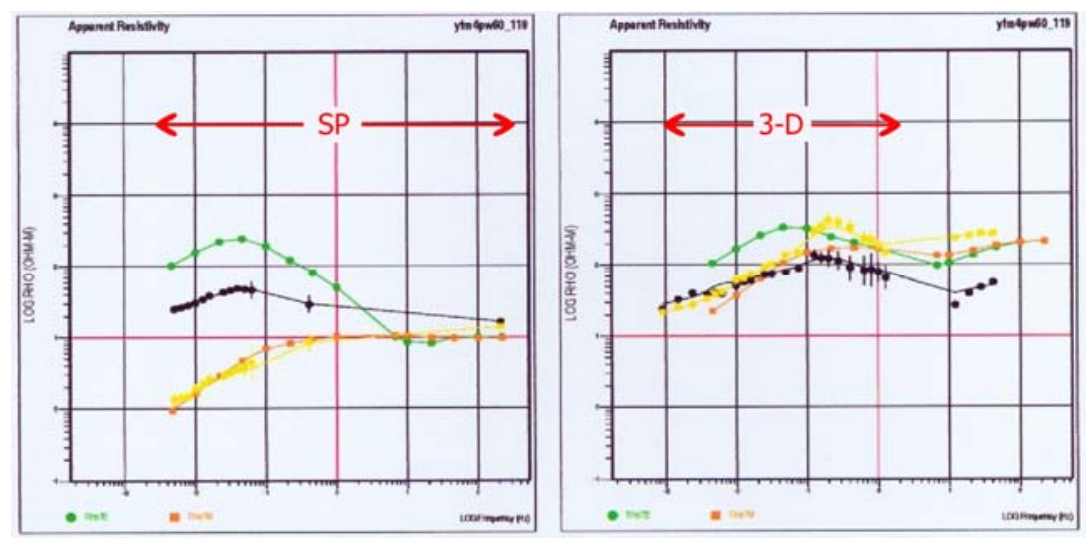

Figure A27b. Profile 4, 2-D resistivity model 60 - observed (TE-black, TM-yellow) and calculated (TE-green, TM-orange) MT apparent resistivity sounding curves. 3-D label indicates threedimensional character of electromagnetic response. SP label indicates electrical resistivity structure is sub-parallel to the profile direction. 

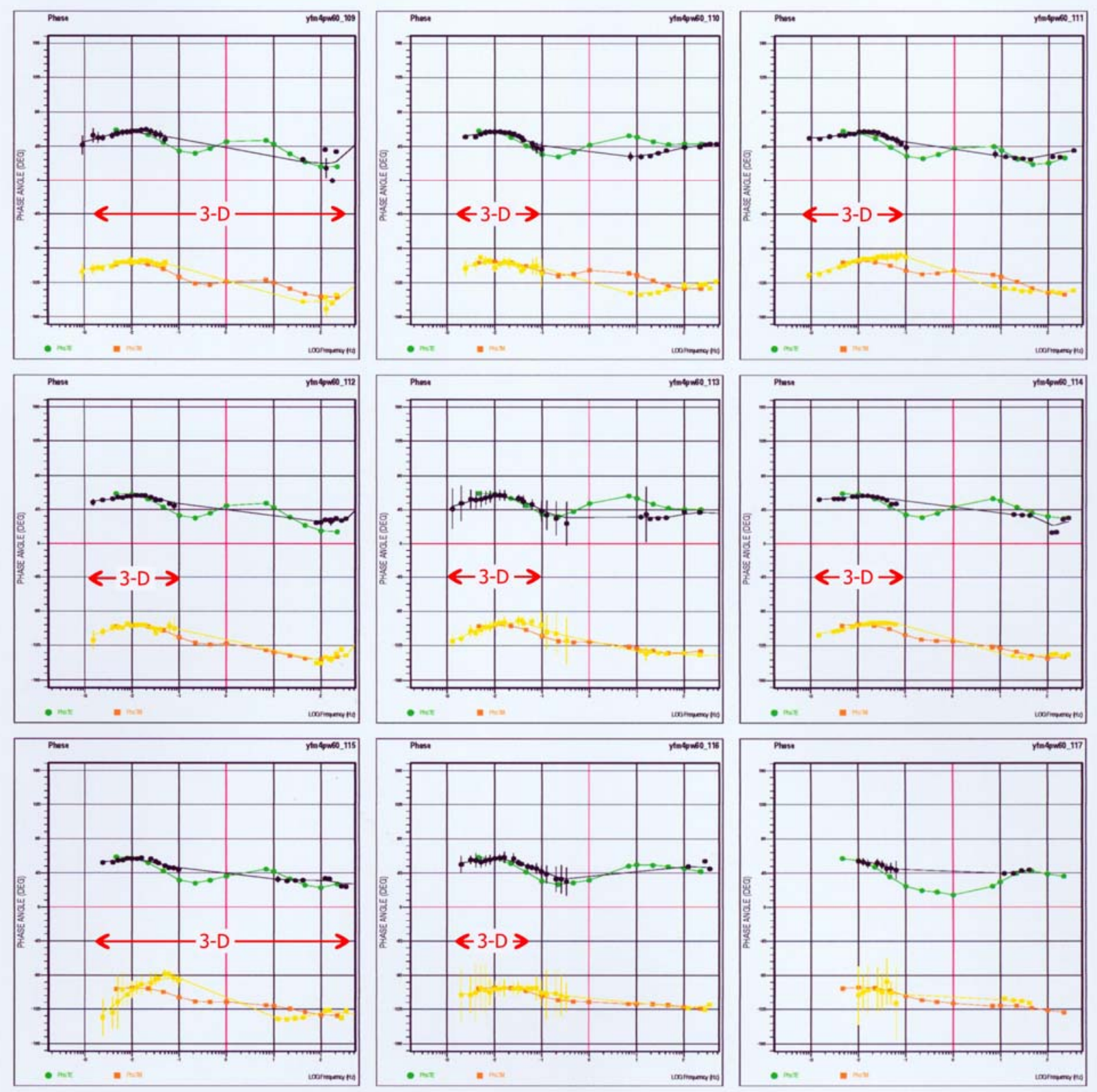

Figure A28a. Profile 4, 2-D resistivity model 60 - observed (TE-black, TM-yellow) and calculated (TE-green, TM-orange) MT impedance phase curves. 3-D label indicates three-dimensional character of electromagnetic response. SP label indicates electrical resistivity structure is subparallel to the profile direction. 

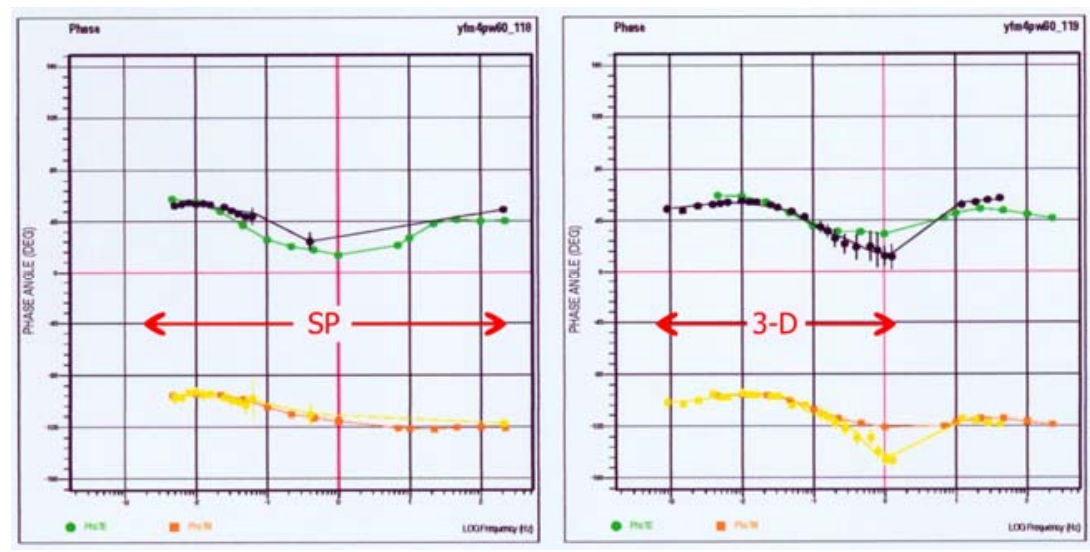

Figure A28b. Profile 4, 2-D resistivity model 60 - observed (TE-black, TM-yellow) and calculated (TE-green, TM-orange) MT impedance phase curves. 3-D label indicates three-dimensional character of electromagnetic response. SP label indicates electrical resistivity structure is subparallel to the profile direction. 


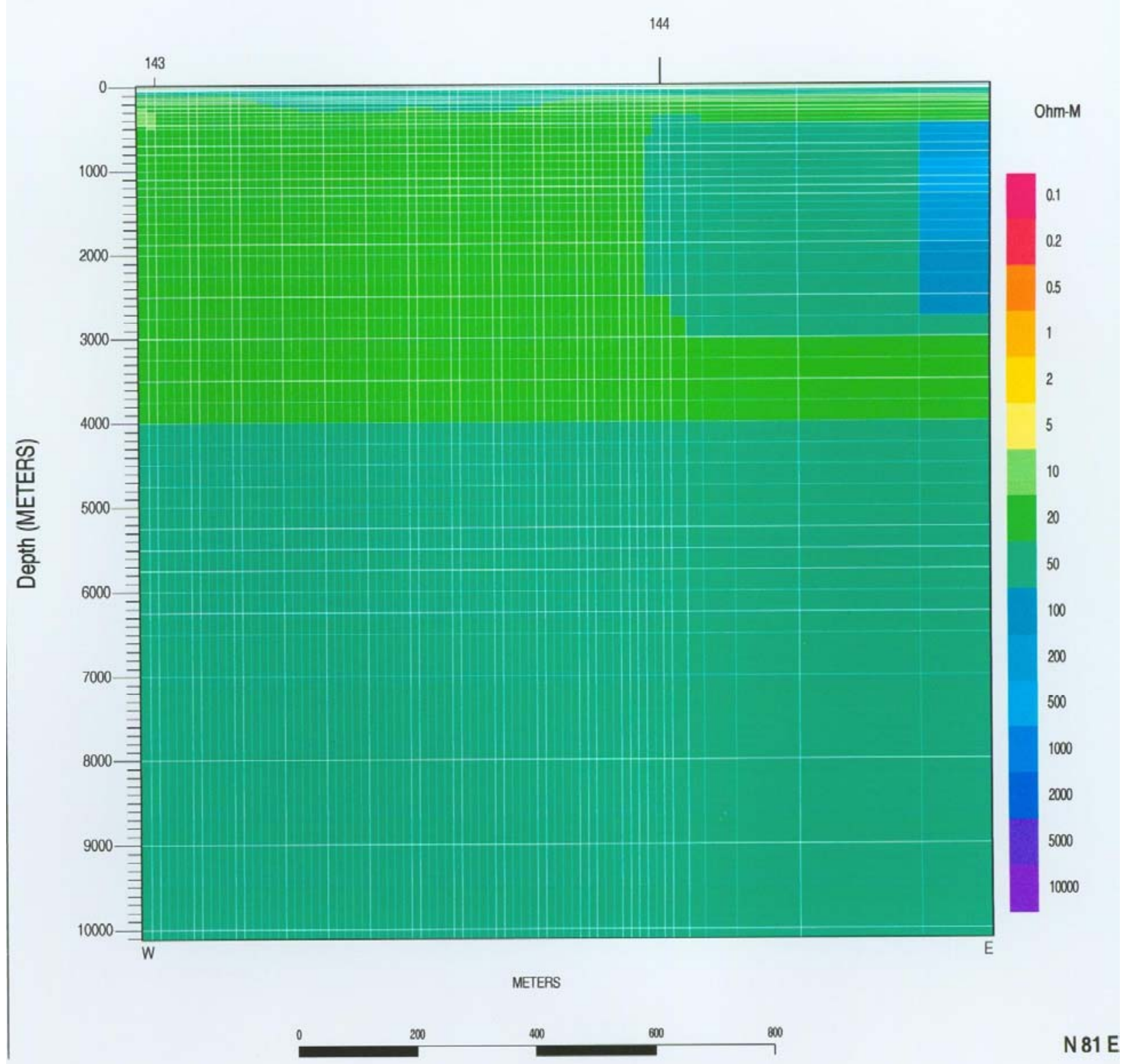

Figure A29. Profile 5, 2-D resistivity model 24 - depth section. 

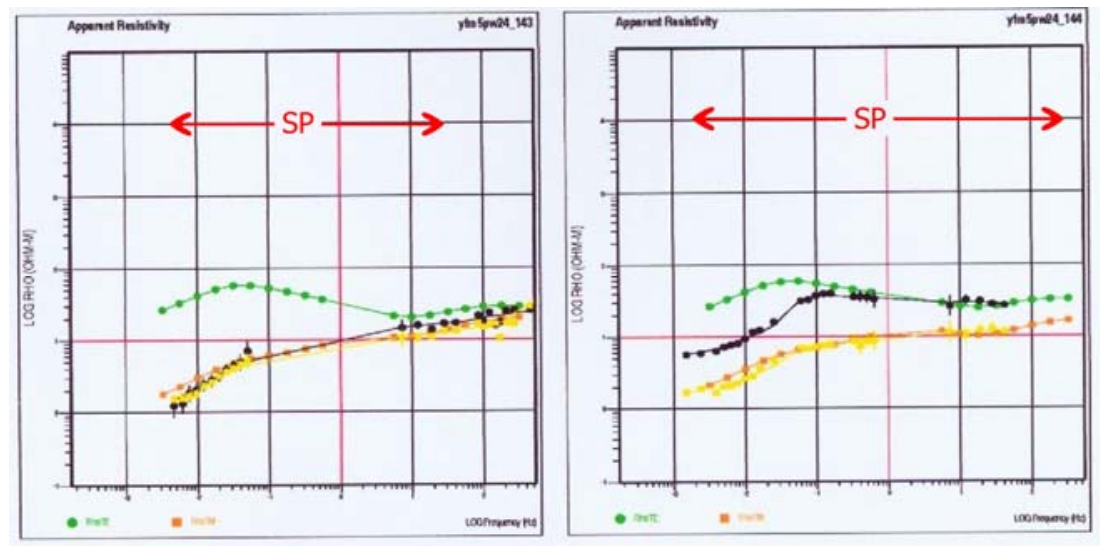

Figure A30. Profile 5, 2-D resistivity model 24 - observed (TE-black, TM-yellow) and calculated (TE-green, TM-orange) MT apparent resistivity sounding curves. 3-D label indicates threedimensional character of electromagnetic response. SP label indicates electrical resistivity structure is sub-parallel to the profile direction.
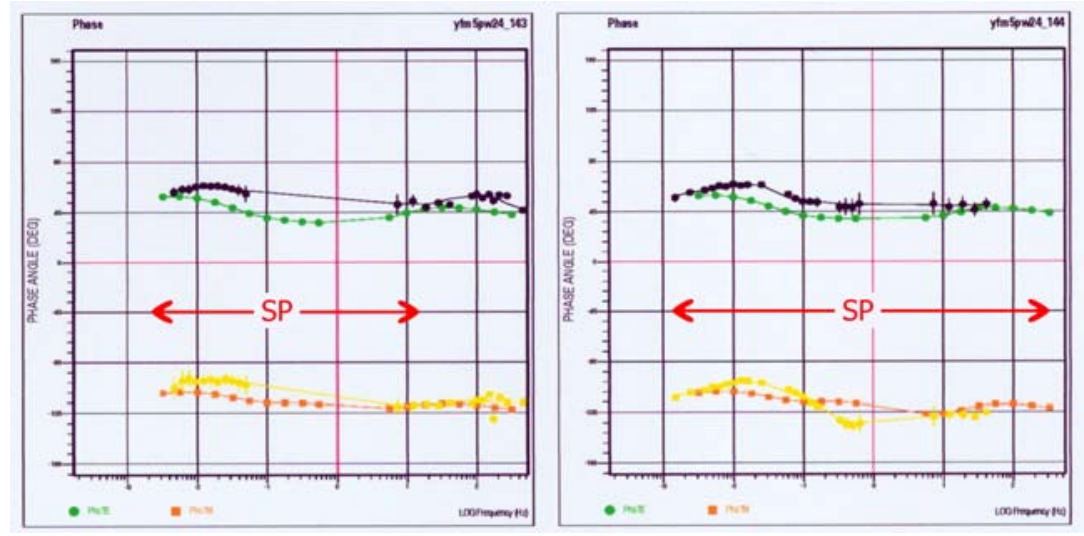

Figure A31. Profile 5, 2-D resistivity model 24 - observed (TE-black, TM-yellow) and calculated (TE-green, TM-orange) MT impedance phase curves. 3-D label indicates three-dimensional character of electromagnetic response. SP label indicates electrical resistivity structure is subparallel to the profile direction. 


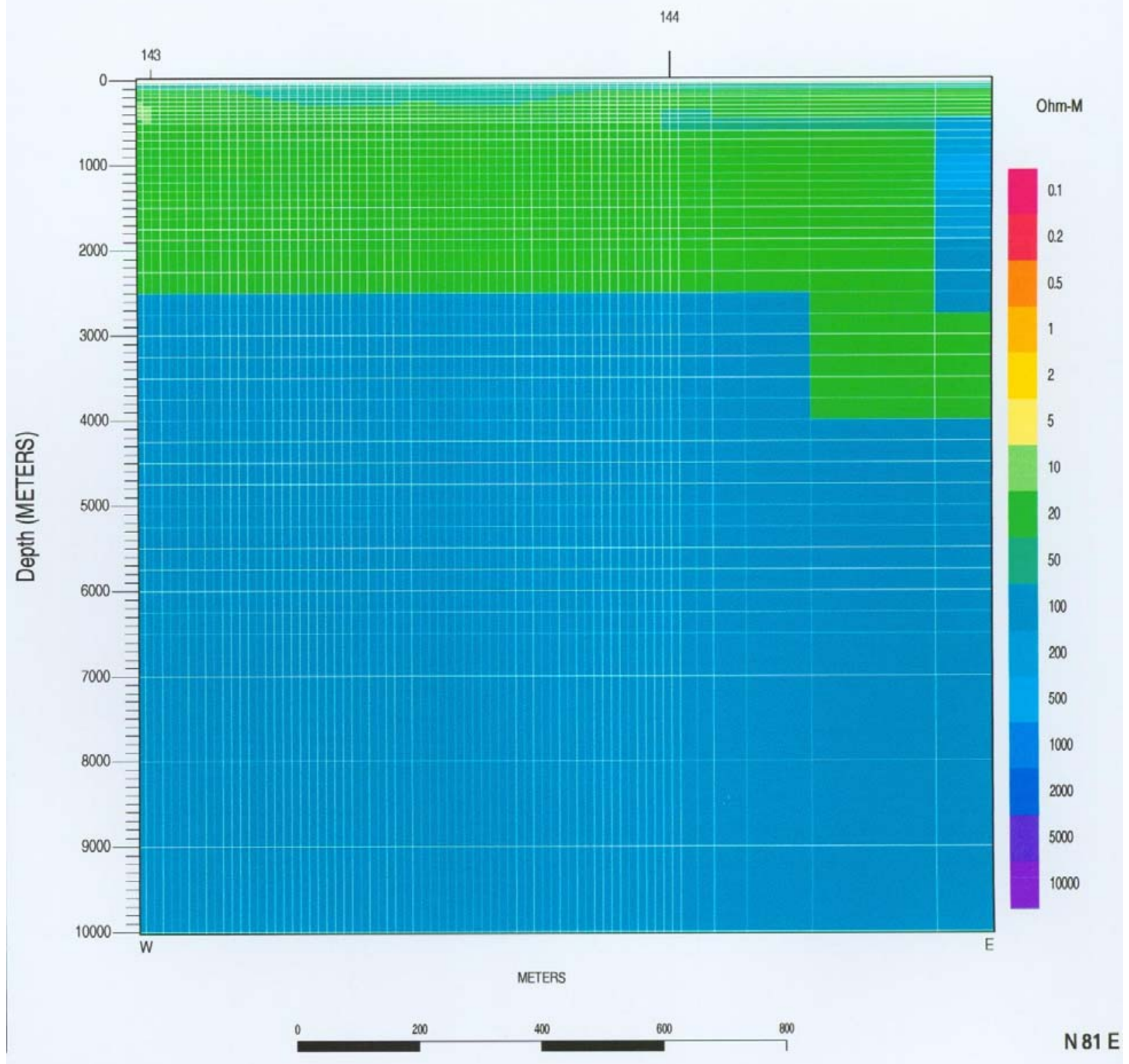

Figure A32. Profile 5, 2-D resistivity model 31 - depth section. 

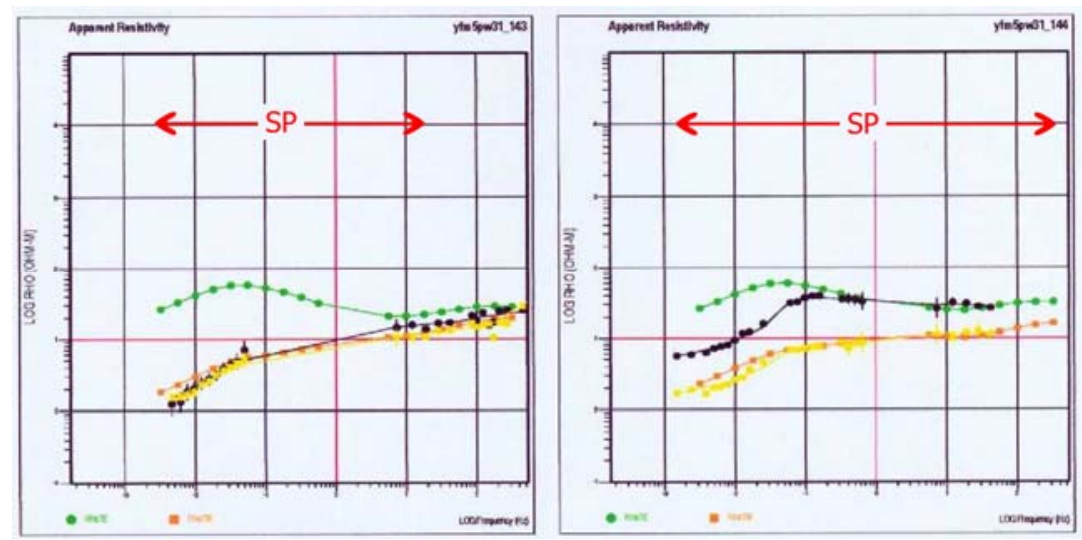

Figure A33. Profile 5, 2-D resistivity model 31 - observed (TE-black, TM-yellow) and calculated (TE-green, TM-orange) MT apparent resistivity sounding curves. 3-D label indicates threedimensional character of electromagnetic response. SP label indicates electrical resistivity structure is sub-parallel to the profile direction.
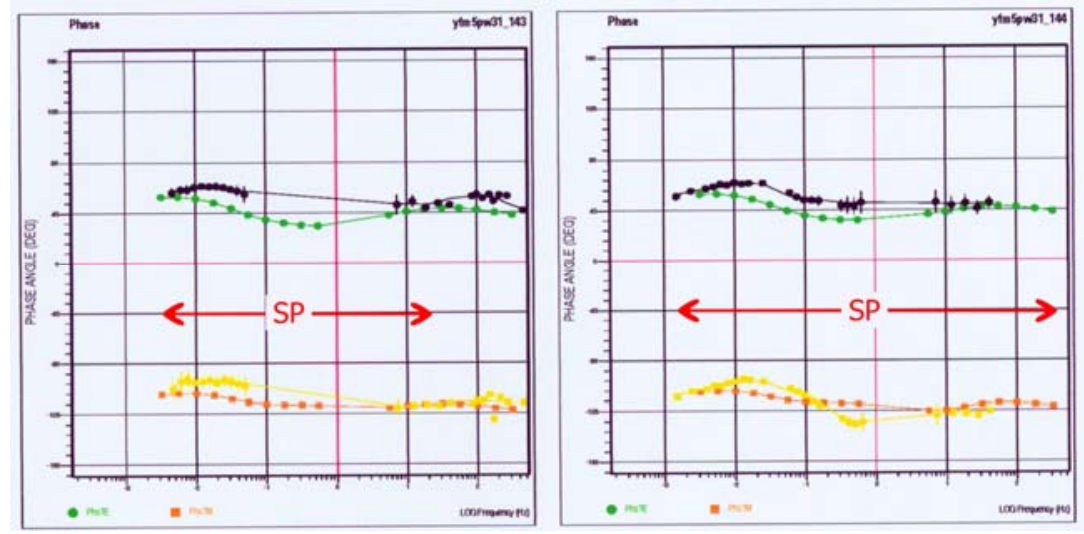

Figure A34. Profile 5, 2-D resistivity model 31 - observed (TE-black, TM-yellow) and calculated (TE-green, TM-orange) MT impedance phase curves. 3-D label indicates three-dimensional character of electromagnetic response. SP label indicates electrical resistivity structure is subparallel to the profile direction. 


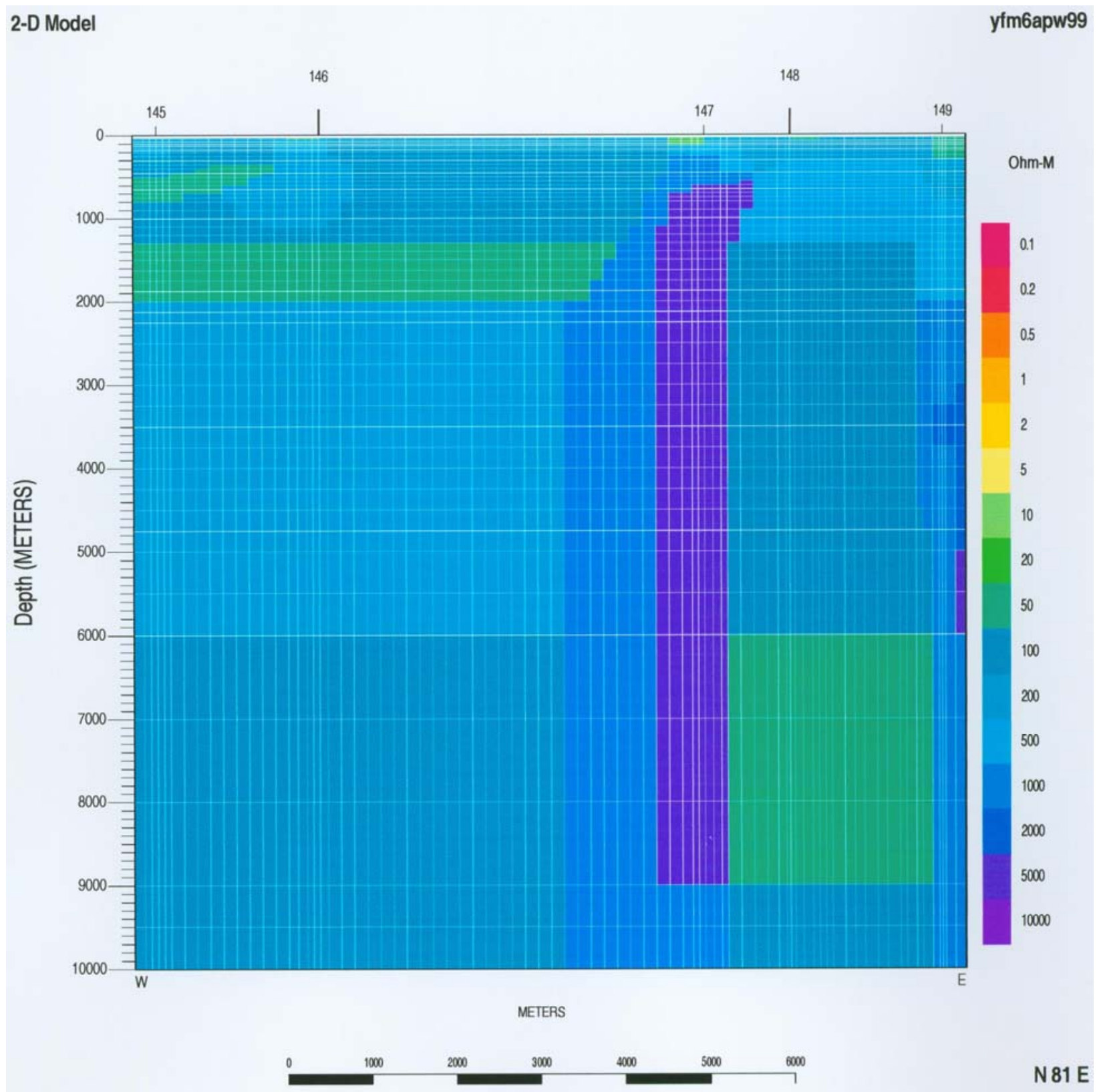

Figure A35. Profile 6a, 2-D resistivity model 99 - depth section. 

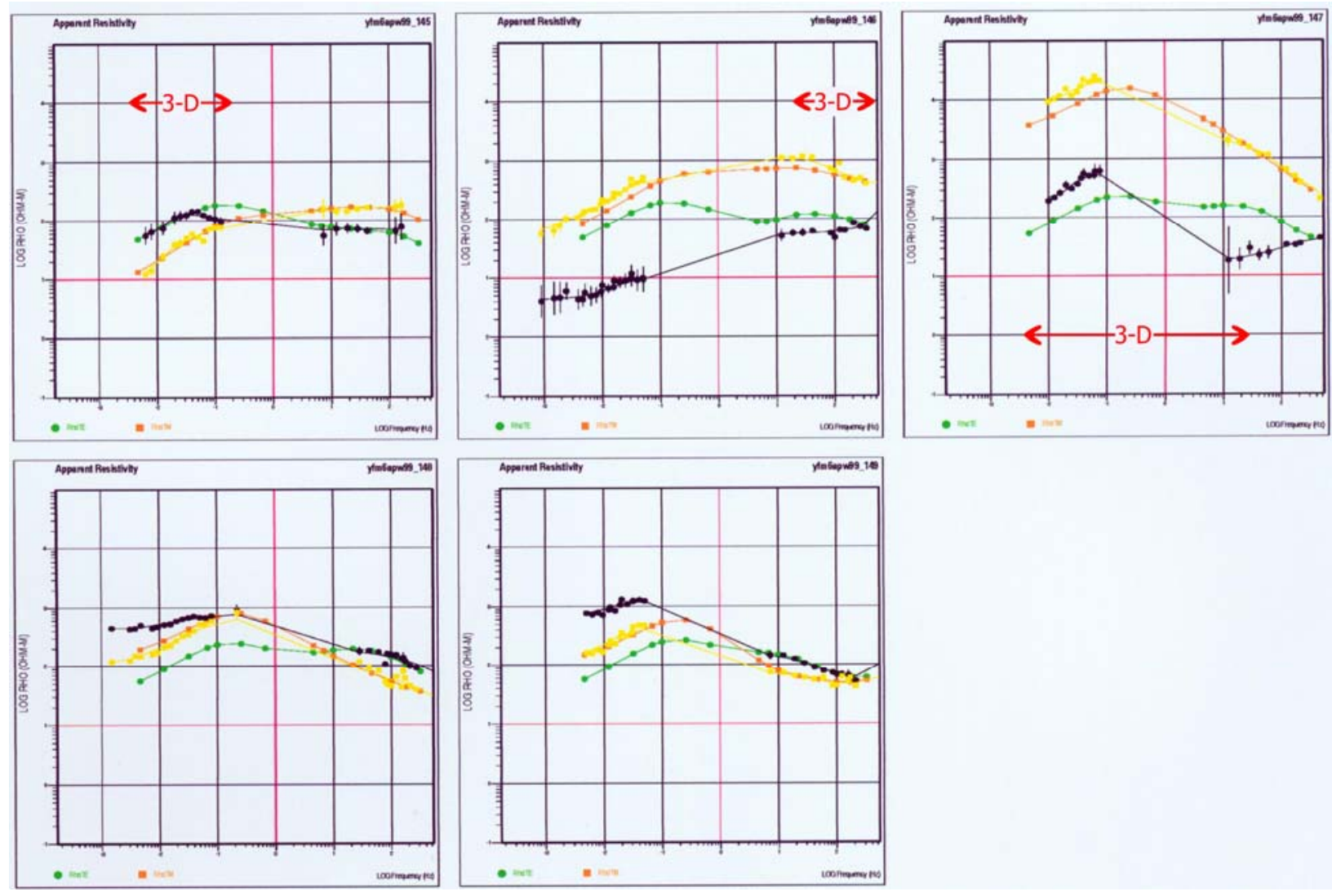

Figure A36. Profile 6a, 2-D resistivity model 99 - observed (TE-black, TM-yellow) and calculated (TE-green, TM-orange) MT apparent resistivity sounding curves. 3-D label indicates threedimensional character of electromagnetic response. SP label indicates electrical resistivity structure is sub-parallel to the profile direction. 

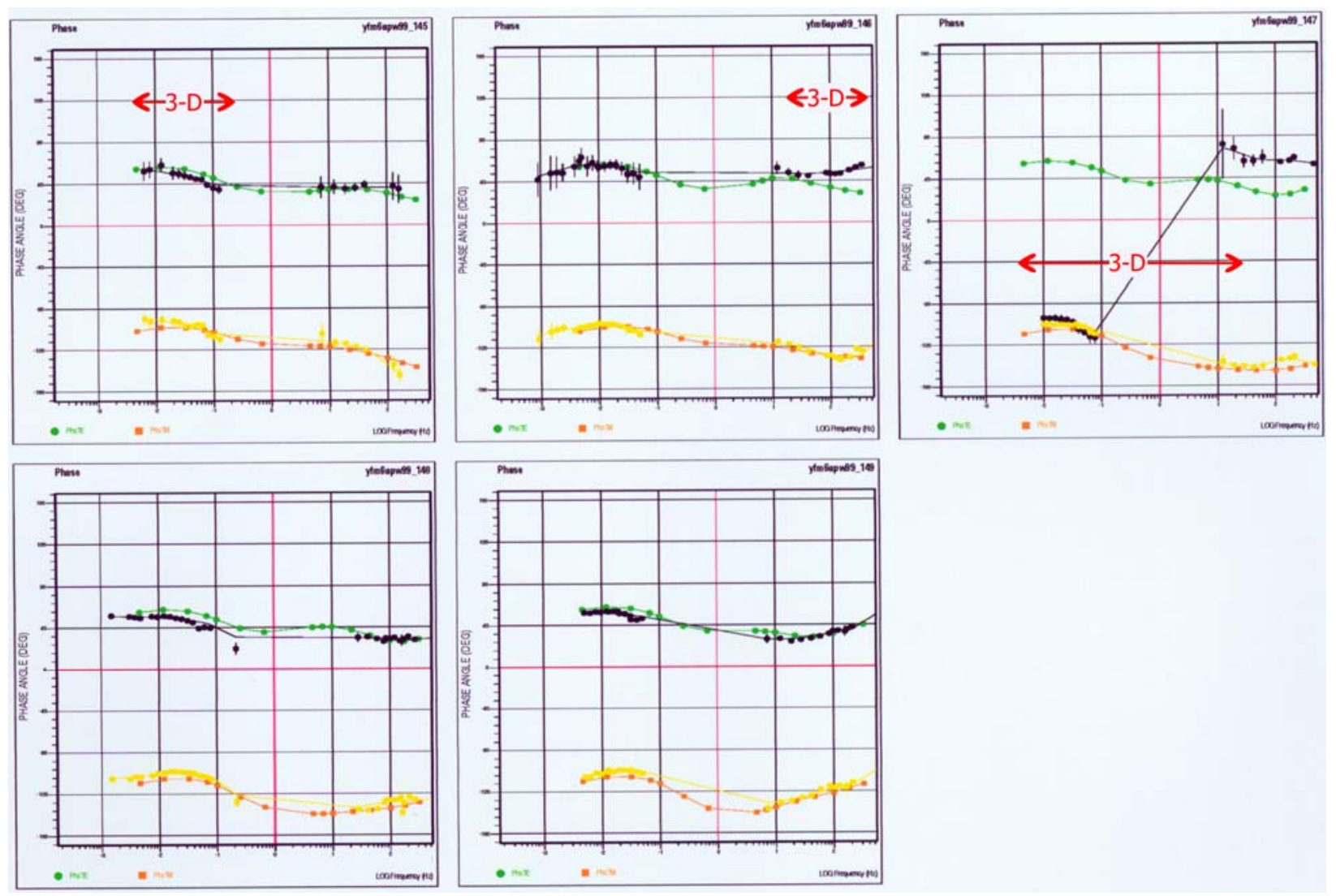

Figure A37. Profile 6a, 2-D resistivity model 99 - observed (TE-black, TM-yellow) and calculated (TE-green, TM-orange) MT impedance phase curves. 3-D label indicates three-dimensional character of electromagnetic response. SP label indicates electrical resistivity structure is subparallel to the profile direction. 


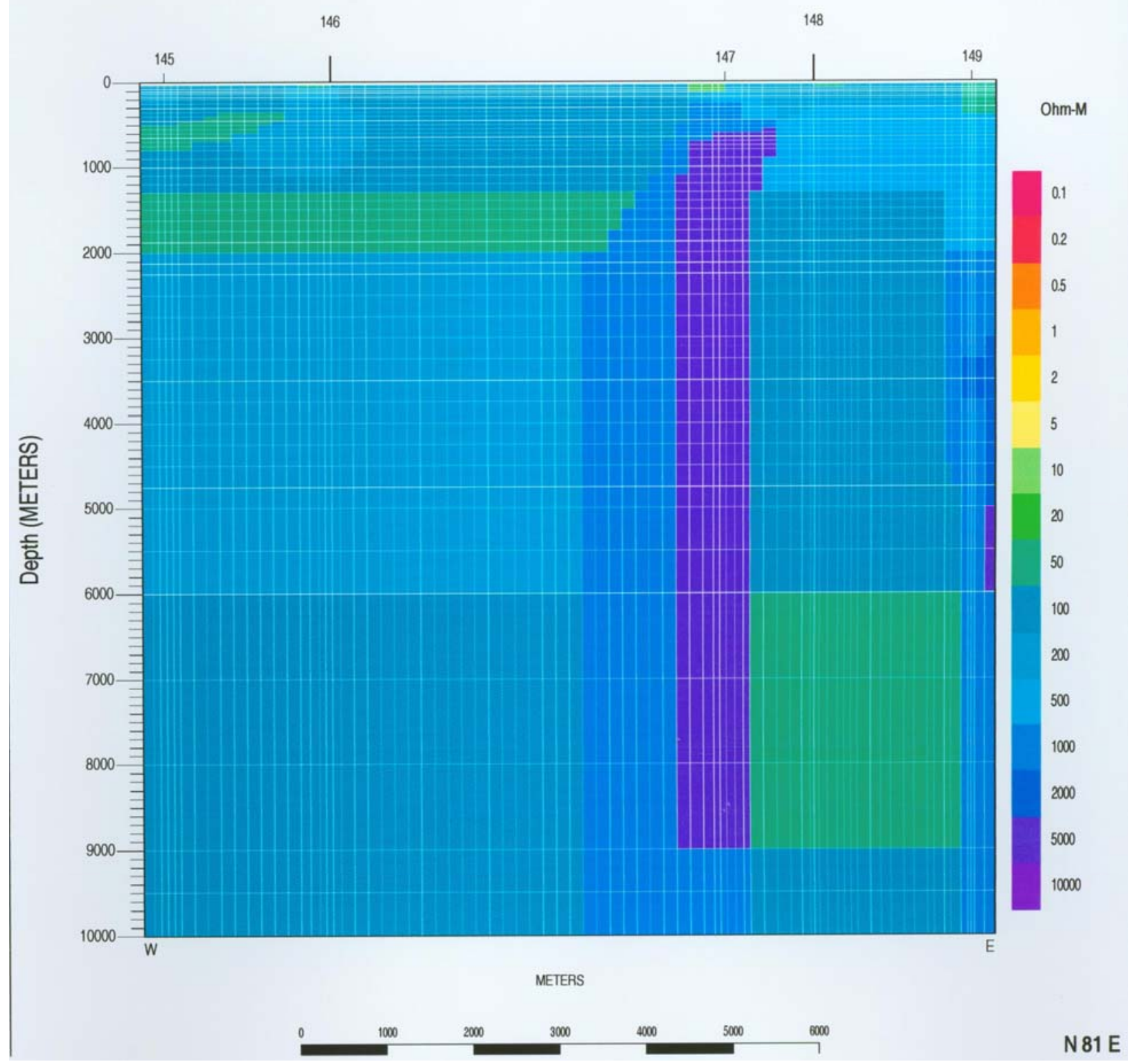

Figure A38. Profile 6a, 2-D resistivity model 100 - depth section. 

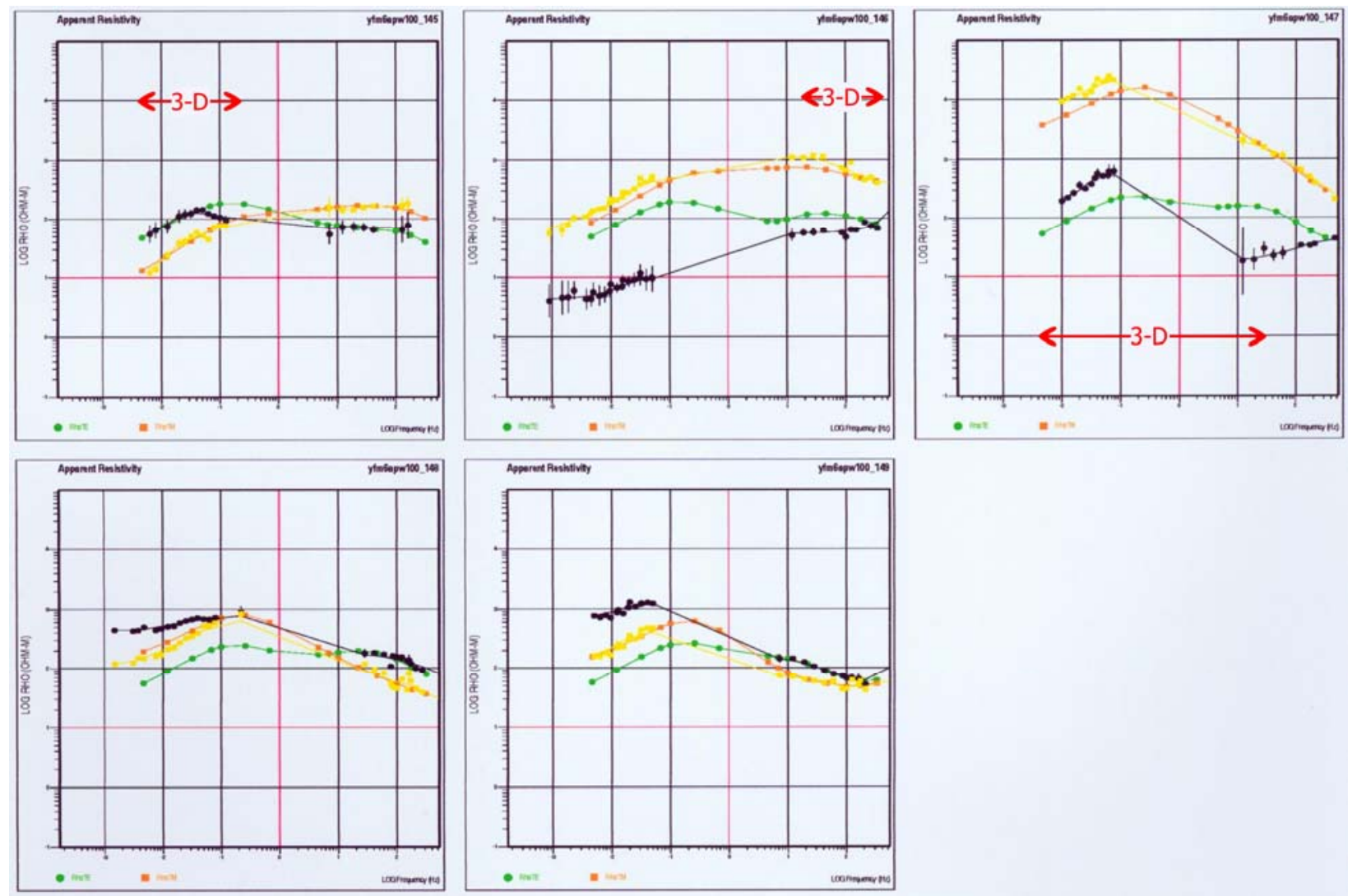

Figure A39. Profile 6a, 2-D resistivity model 100 - observed (TE-black, TM-yellow) and calculated (TE-green, TM-orange) MT apparent resistivity sounding curves. 3-D label indicates threedimensional character of electromagnetic response. SP label indicates electrical resistivity structure is sub-parallel to the profile direction. 

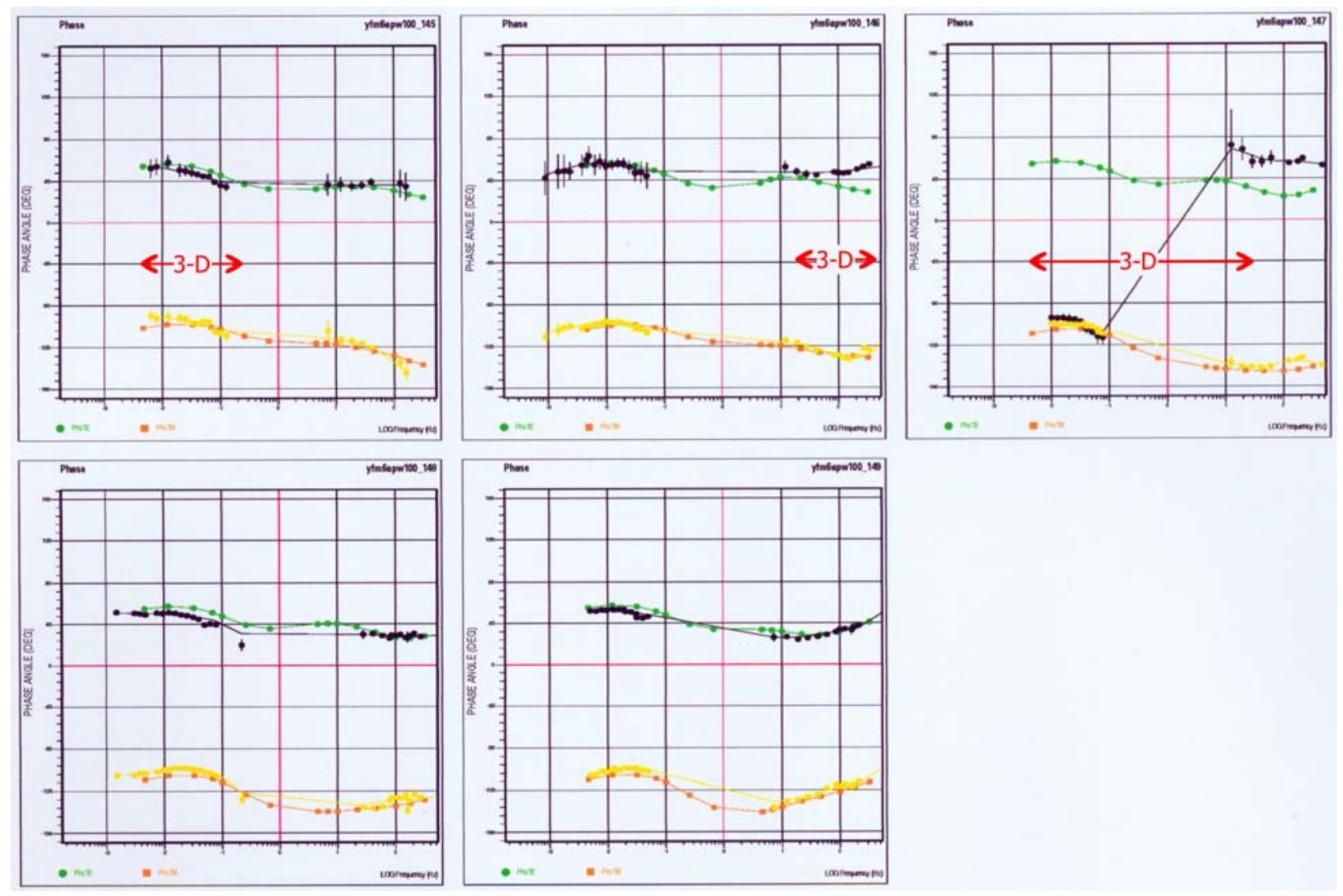

Figure A40. Profile 6a, 2-D resistivity model 100 - observed (TE-black, TM-yellow) and calculated (TE-green, TM-orange) MT impedance phase curves. 3-D label indic ates three-dimensional character of electromagnetic response. SP label indicates electrical resistivity structure is subparallel to the profile direction. 


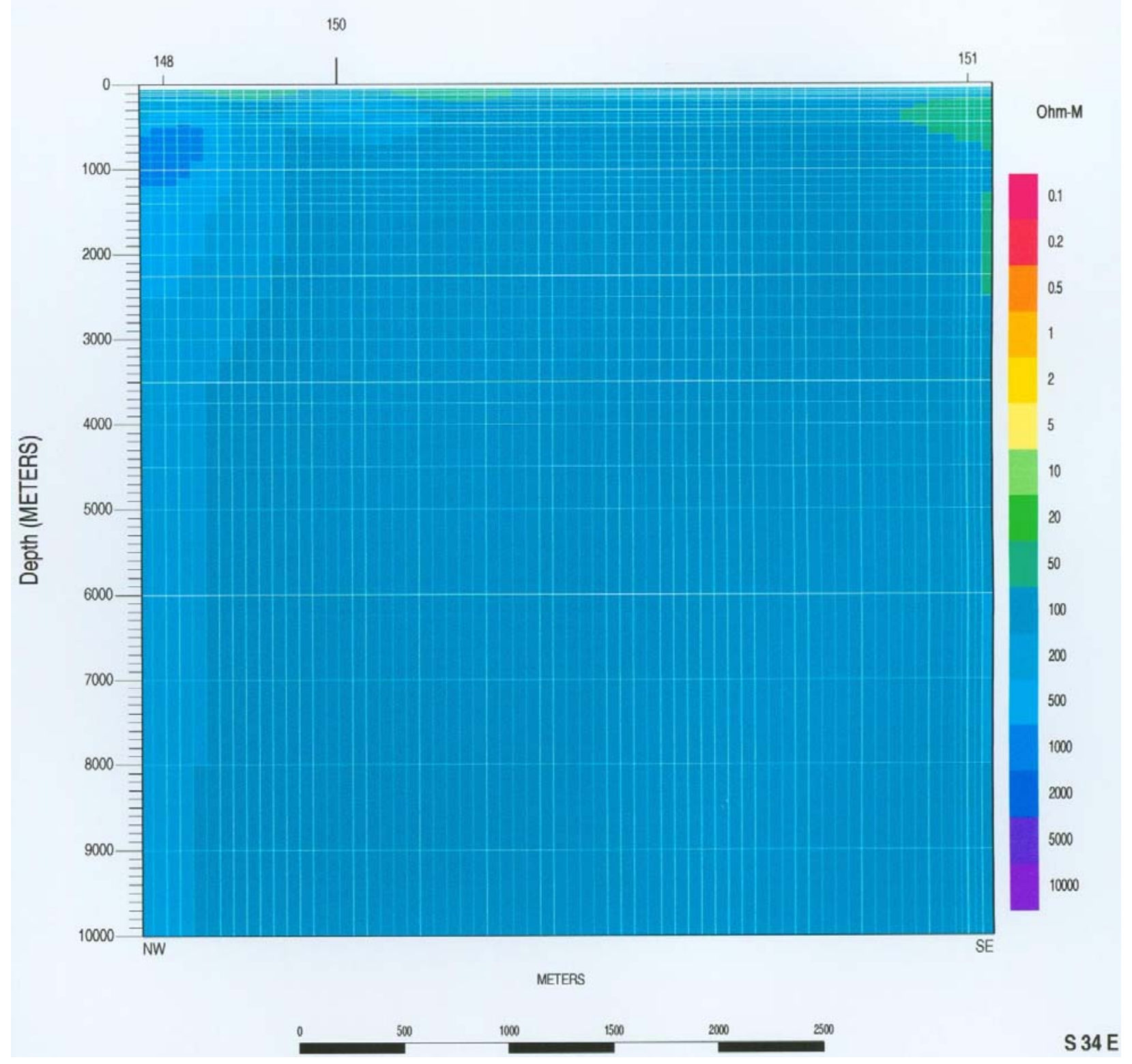

Figure A41. Profile 6b, 2-D resistivity model 1 - depth section. 

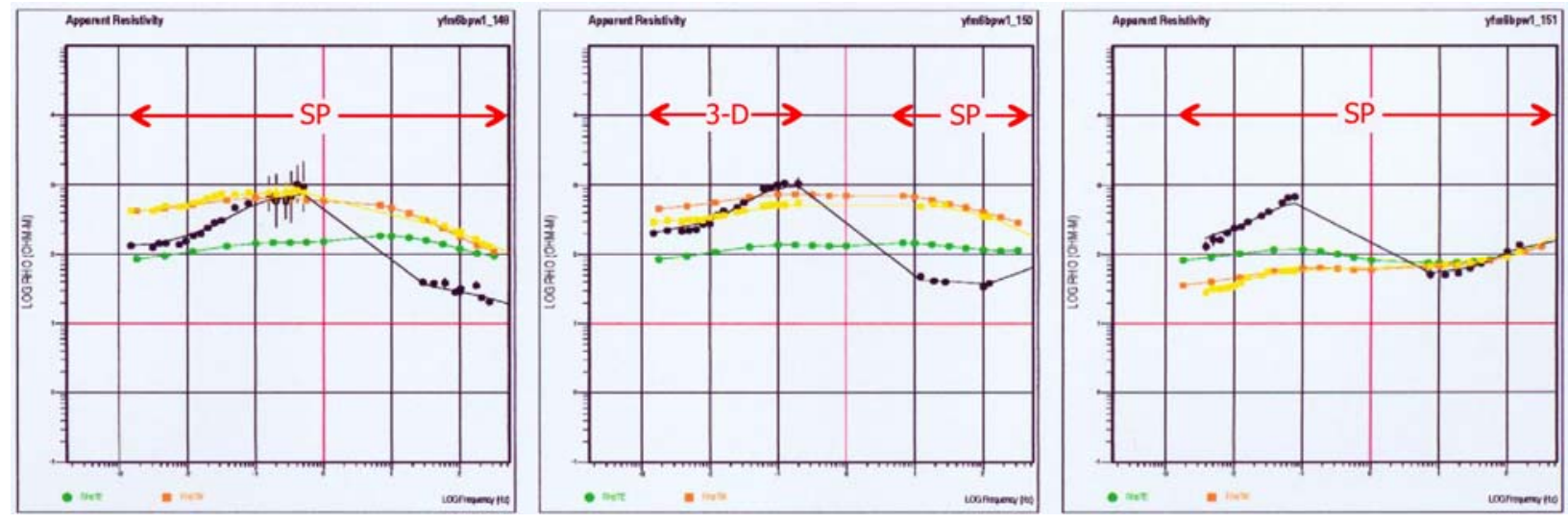

Figure A42. Profile 6b, 2-D resistivity model 1 - observed (TE-black, TM-yellow) and calculated (TE-green, TM-orange) MT apparent resistivity sounding curves. 3-D label indicates threedimensional character of electromagnetic response. SP label indicates electrical resistivity structure is sub-parallel to the profile direction.
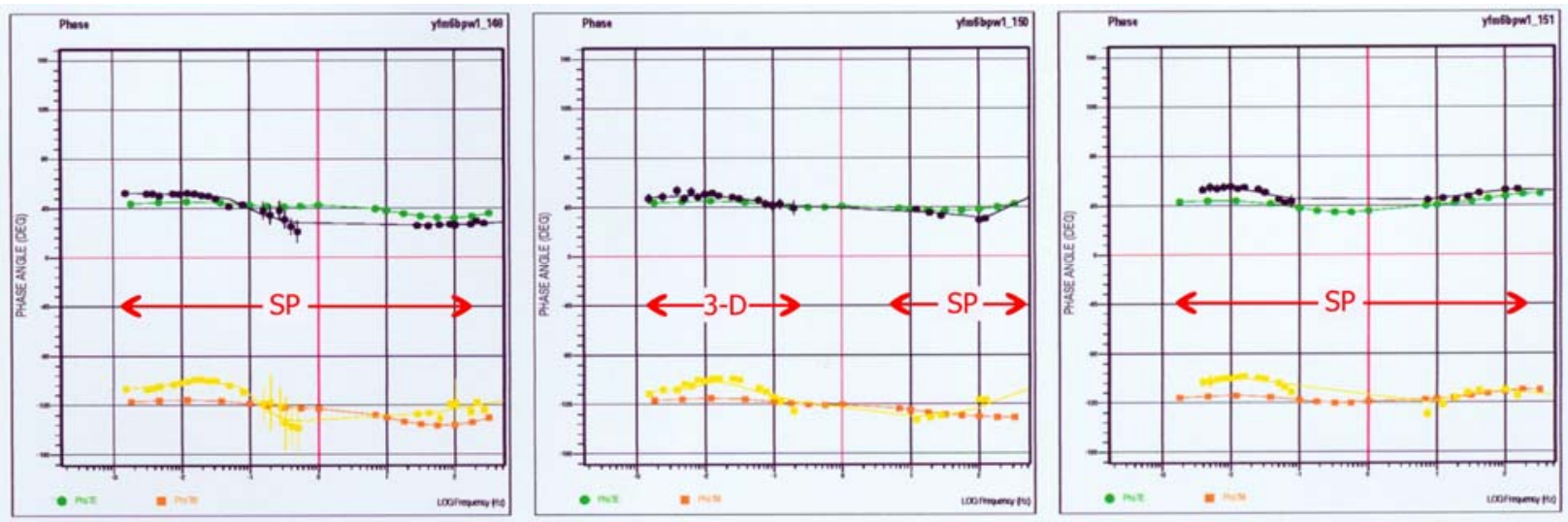

Figure A43. Profile 6b, 2-D resistivity model 1 - observed (TE-black, TM-yellow) and calculated (TE-green, TM-orange) MT impedance phase curves. 3-D label indicates three-dimensional character of electromagnetic response. SP label indicates electrical resistivity structure is subparallel to the profile direction. 


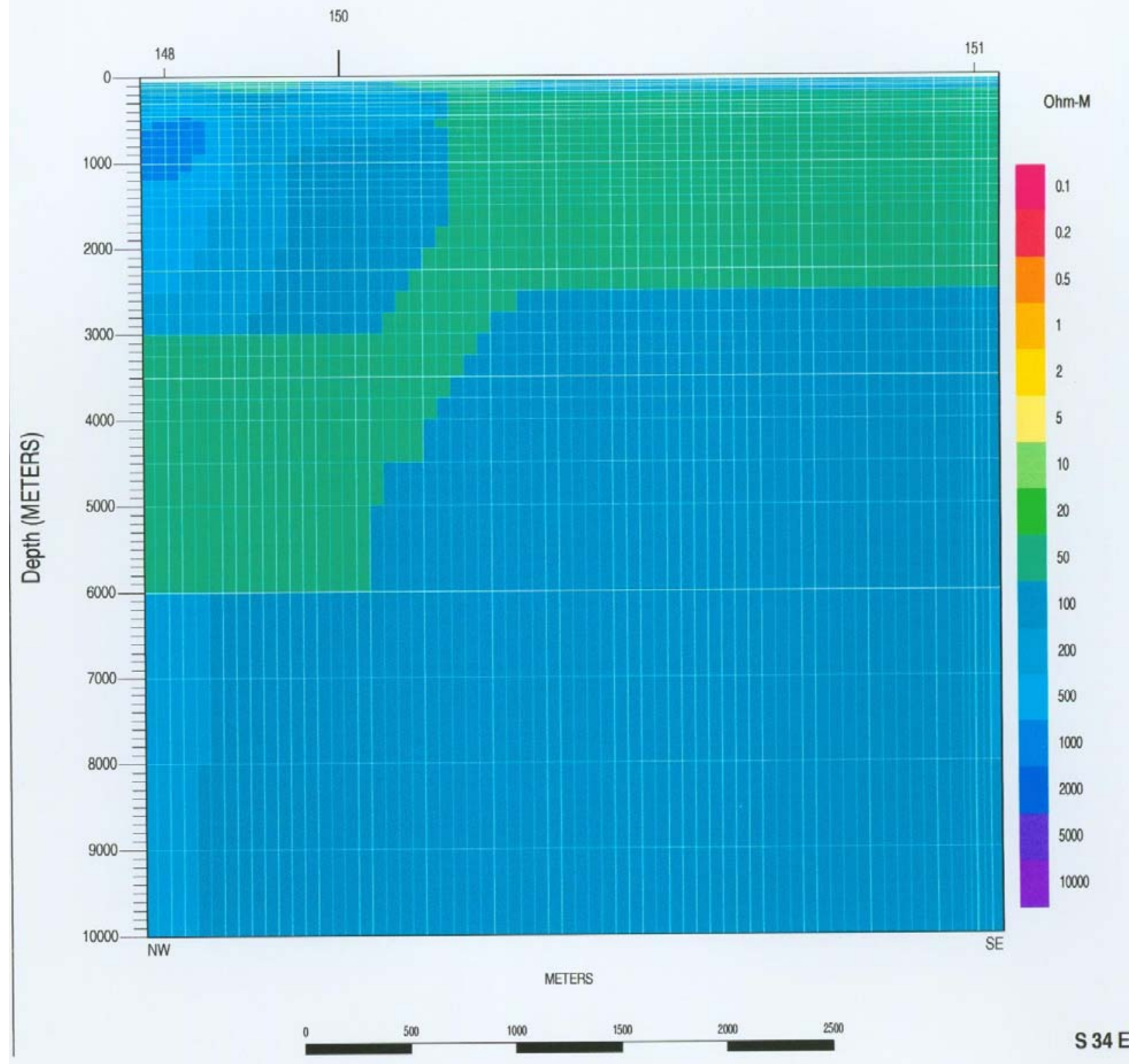

Figure A44. Profile 6b, 2-D resistivity model 9 - depth section. 

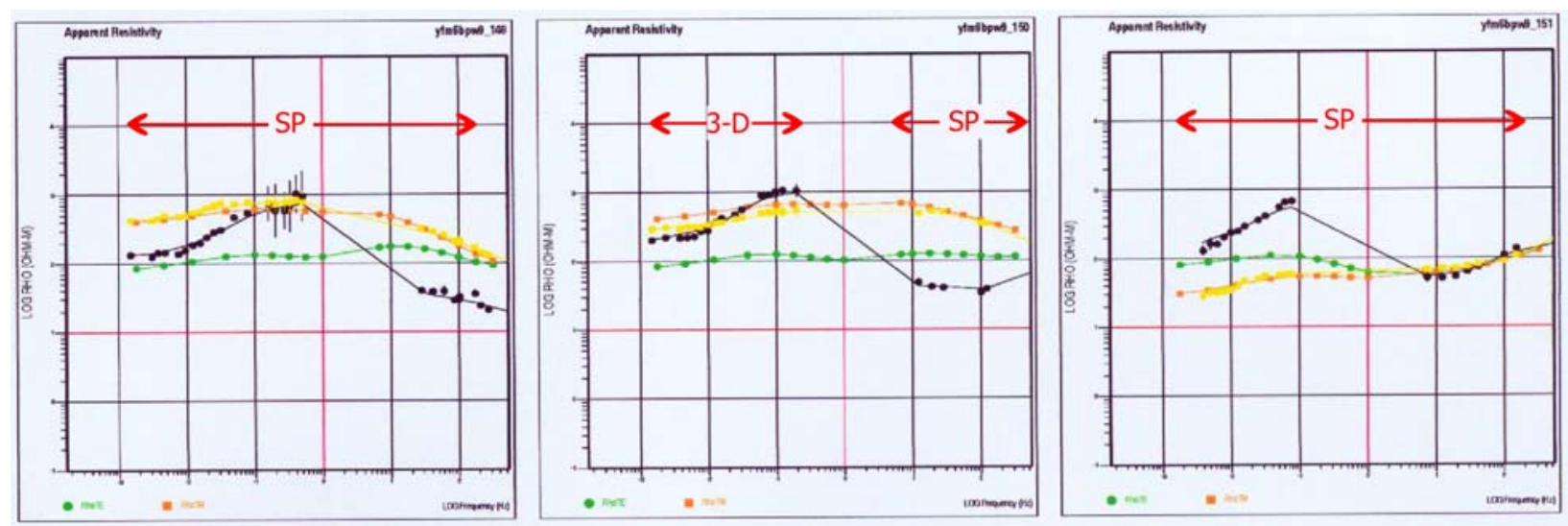

Figure A45. Profile 6b, 2-D resistivity model 9 - observed (TE-black, TM-yellow) and calculated (TE-green, TM-orange) MT apparent resistivity sounding curves. 3-D label indicates threedimensional character of electromagnetic response. SP label indicates electrical resistivity structure is sub-parallel to the profile direction.
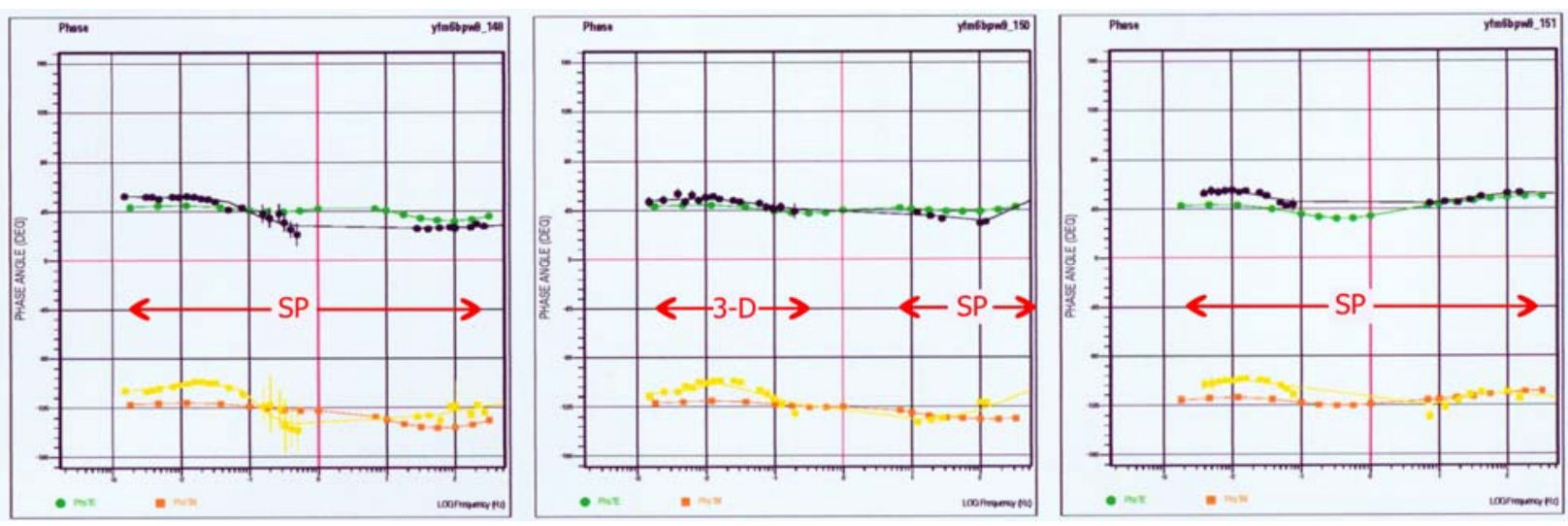

Figure A46. Profile 6b, 2-D resistivity model 9 - observed (TE-black, TM-yellow) and calculated (TE-green, TM-orange) MT impedance phase curves. 3-D label indicates three-dimensional character of electromagnetic response. SP label indicates electrical resistivity structure is subparallel to the profile direction. 


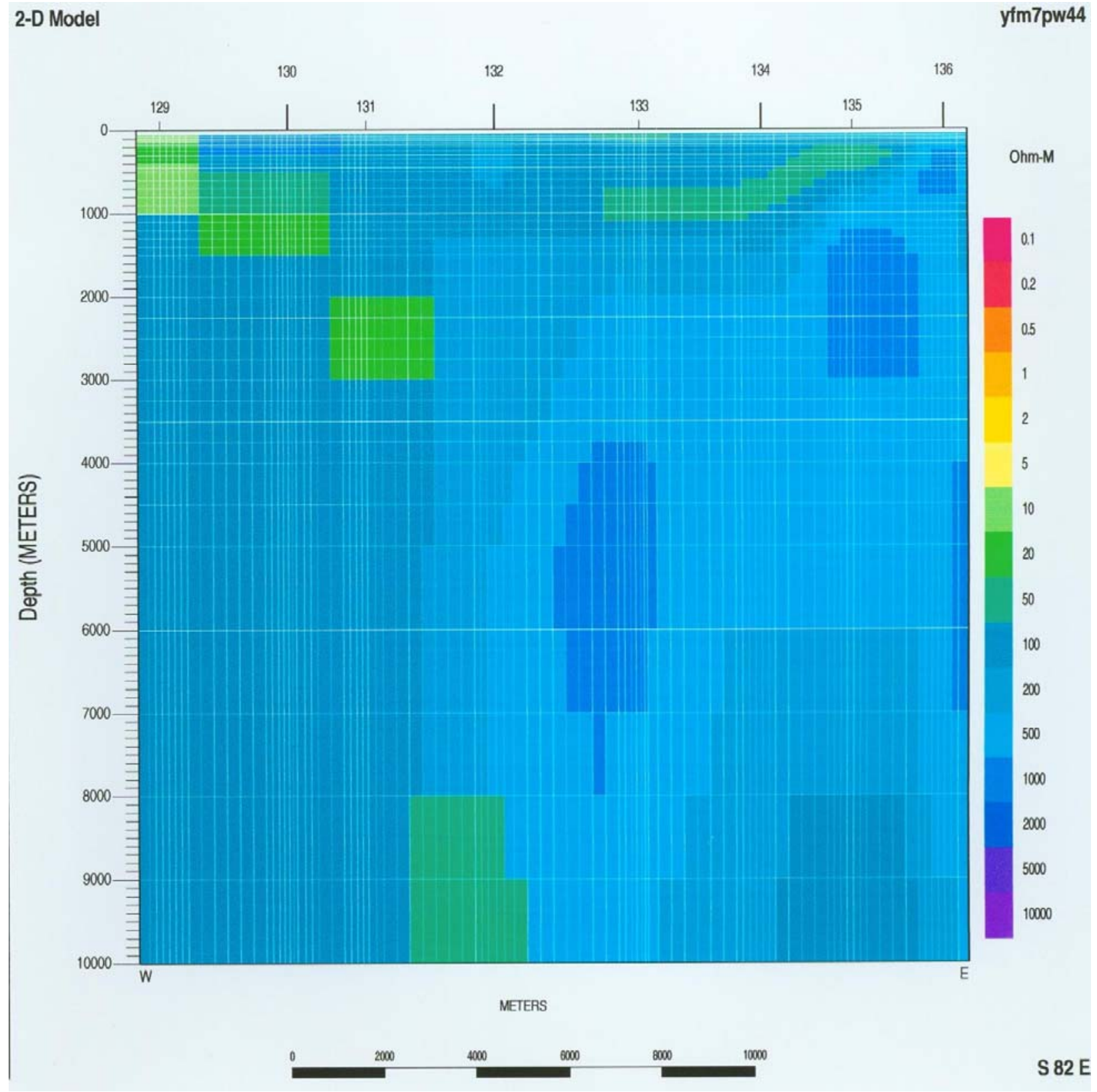

Figure A47. Profile 7, 2-D resistivity model 44 - depth section. 

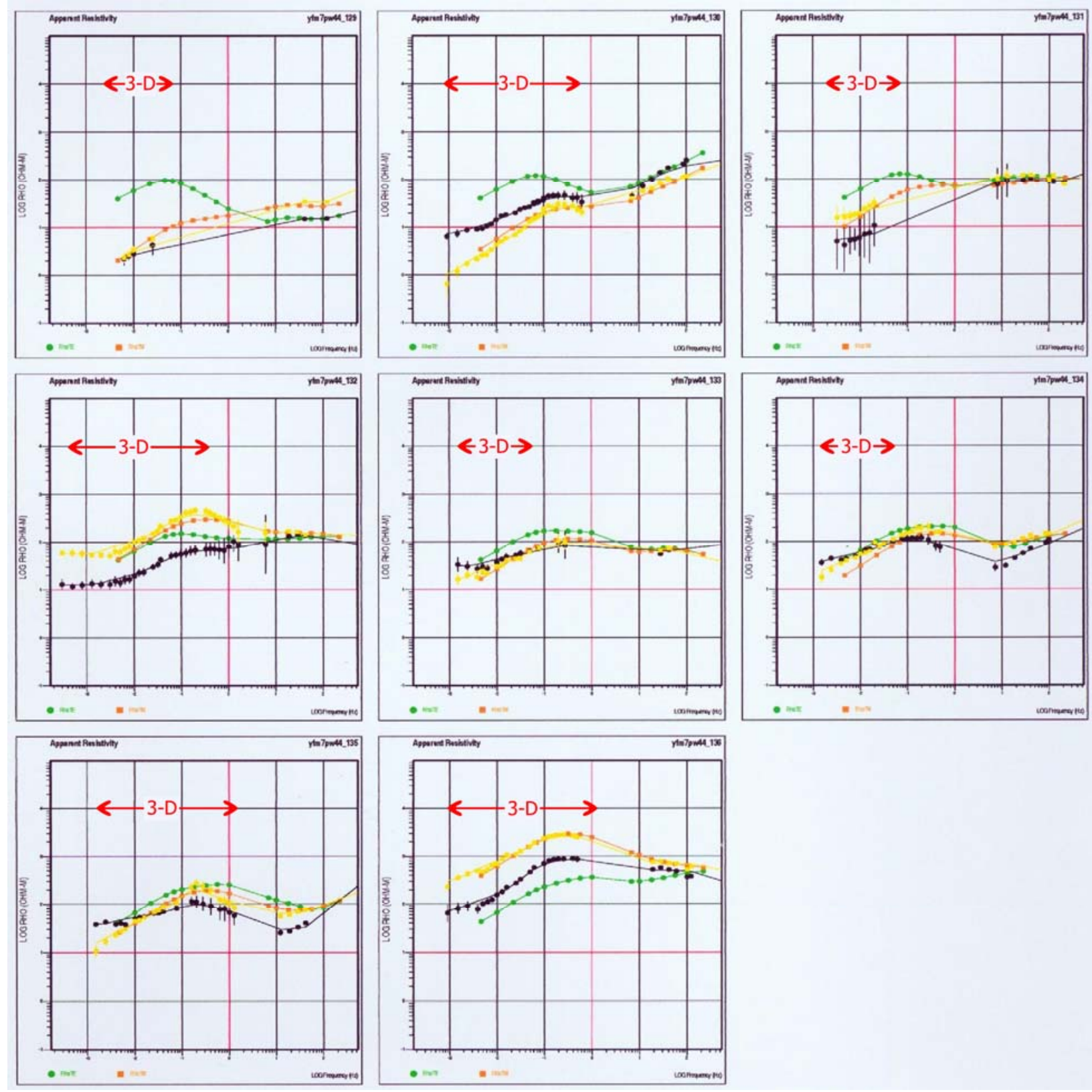

Figure A48. Profile 7, 2-D resistivity model 44 - observed (TE-black, TM-yellow) and calculated (TE-green, TM-orange) MT apparent resistivity sounding curves. 3-D label indicates threedimensional character of electromagnetic response. SP label indicates electrical resistivity structure is sub-parallel to the profile direction. 

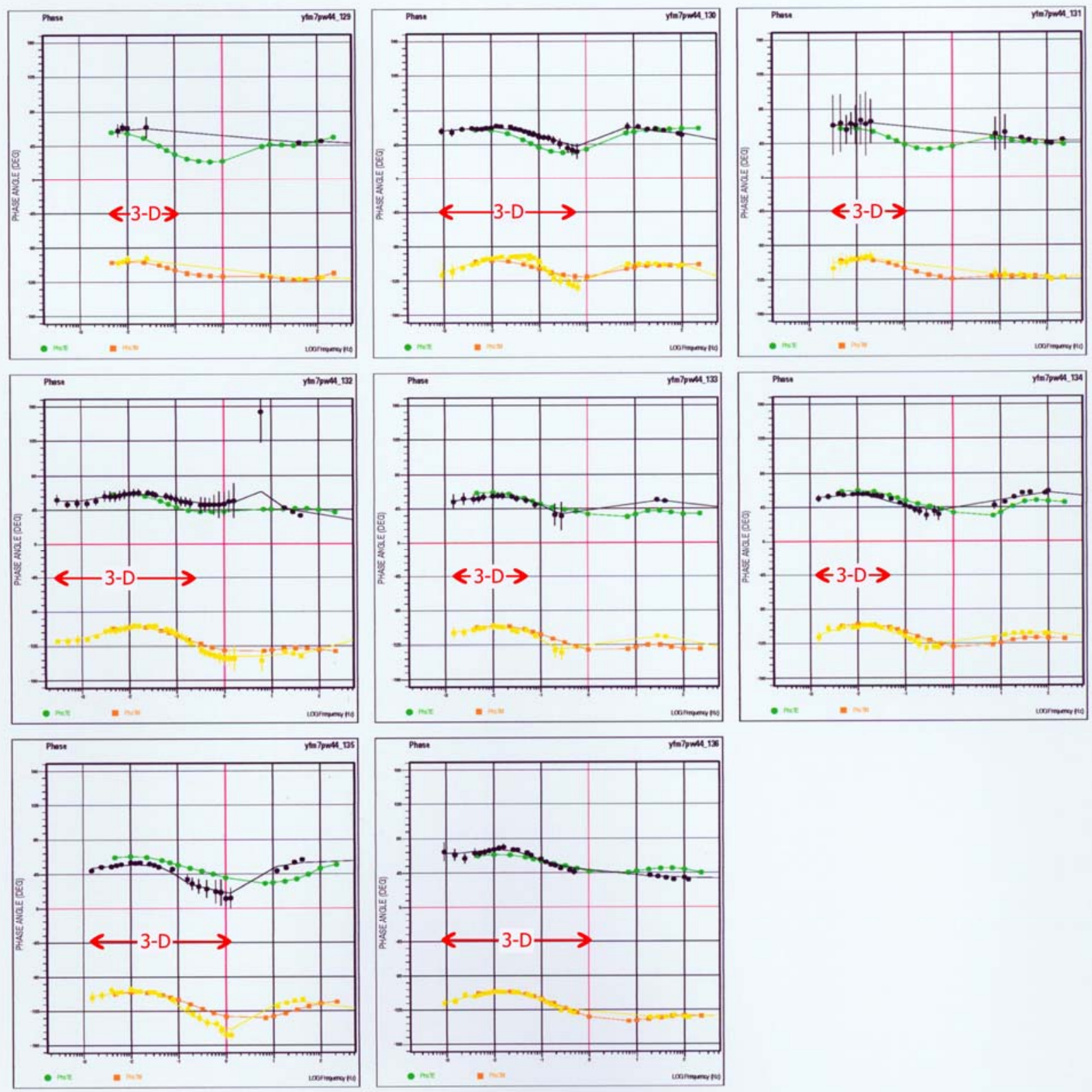

Figure A49. Profile 7, 2-D resistivity model 44 - observed (TE-black, TM-yellow) and calculated (TE-green, TM-orange) MT impedance phase curves. 3-D label indicates three-dimensional character of electromagnetic response. SP label indicates electrical resistivity structure is subparallel to the profile direction. 


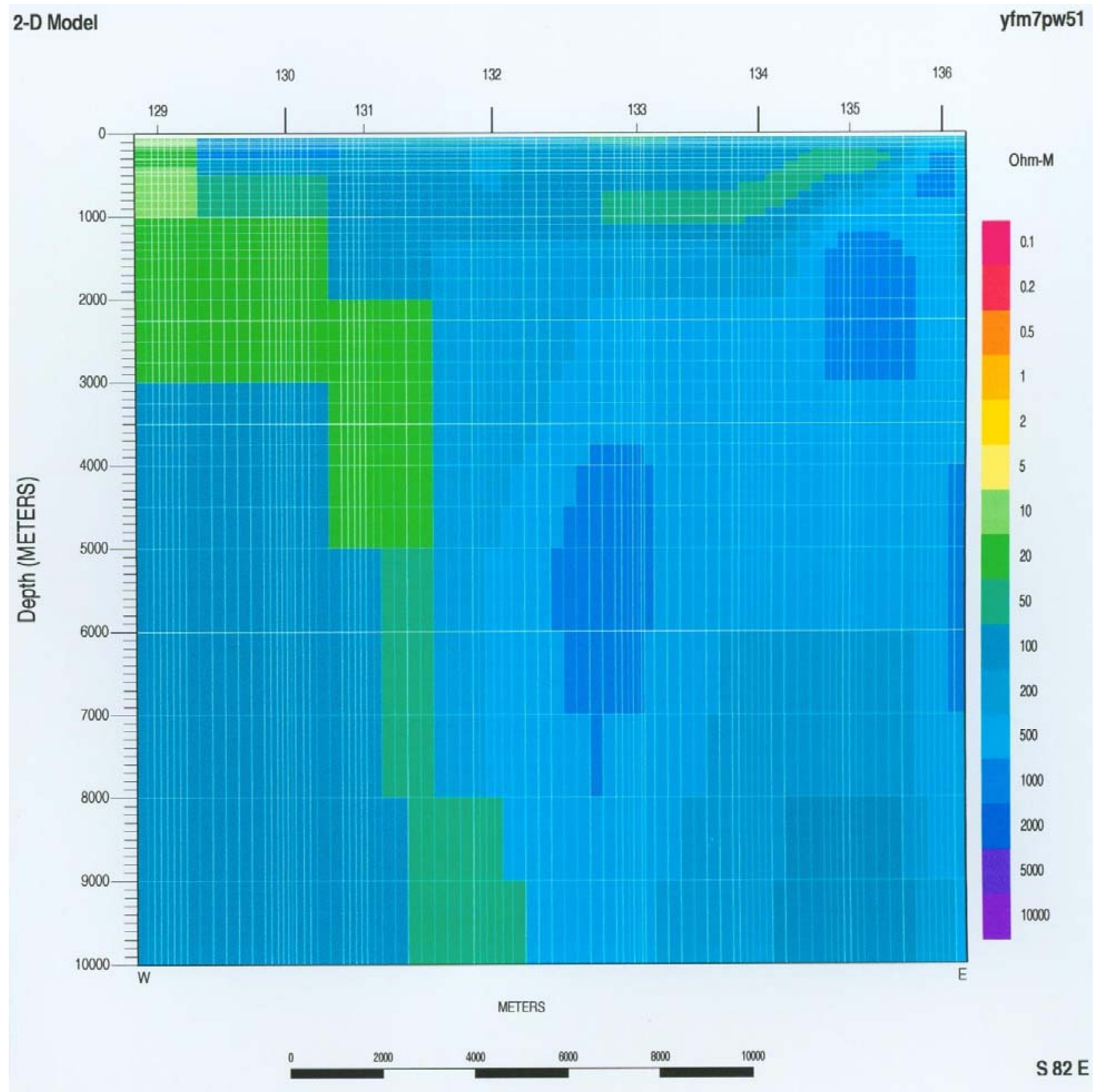

Figure A50. Profile 7, 2-D resistivity model 51 - depth section. 

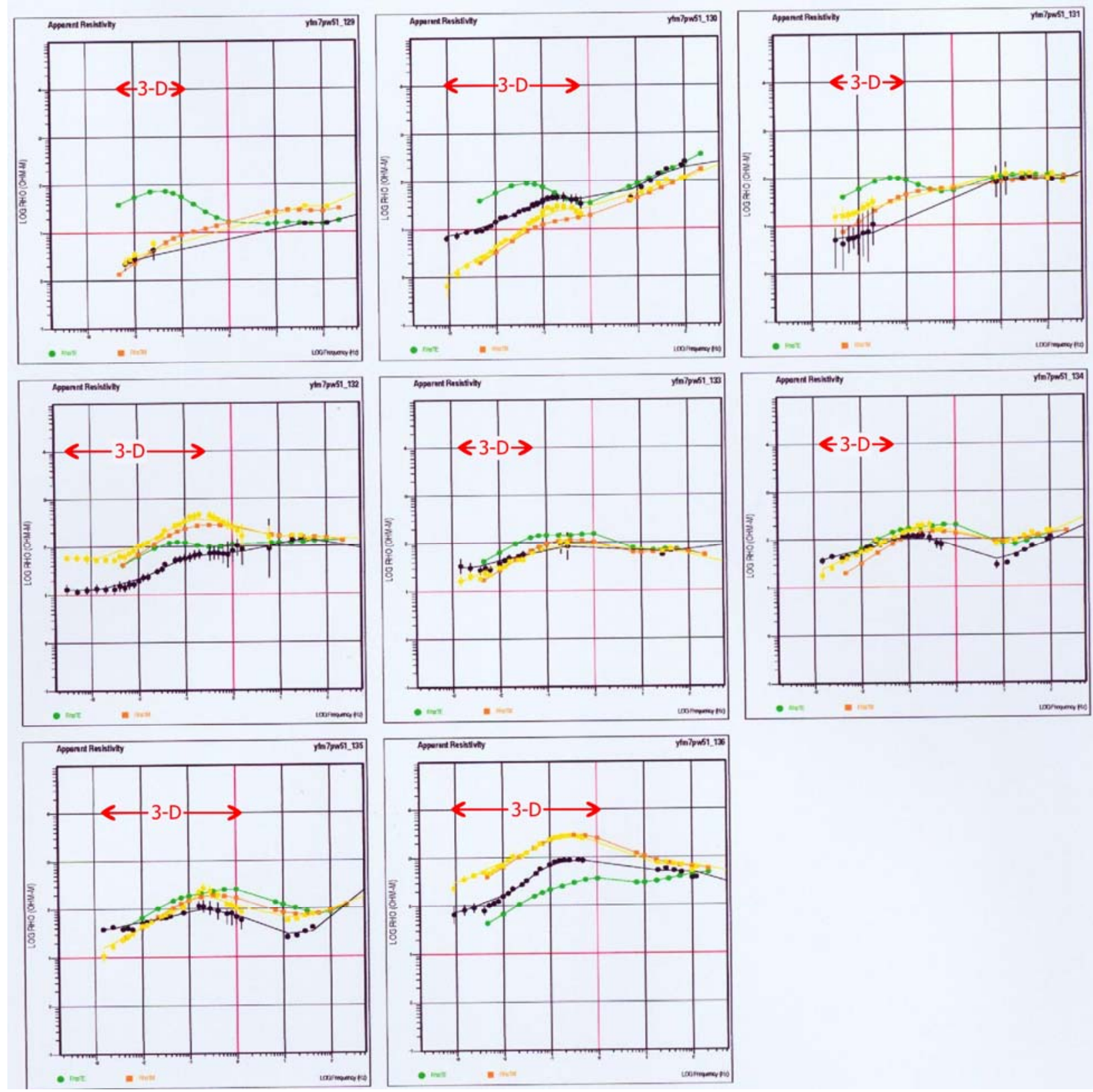

Figure A51. Profile 7, 2-D resistivity model 51 - observed (TE-black, TM-yellow) and calculated (TE-green, TM-orange) MT apparent resistivity sounding curves. 3-D label indicates threedimensional character of electromagnetic response. SP label indicates electrical resistivity structure is sub-parallel to the profile direction. 

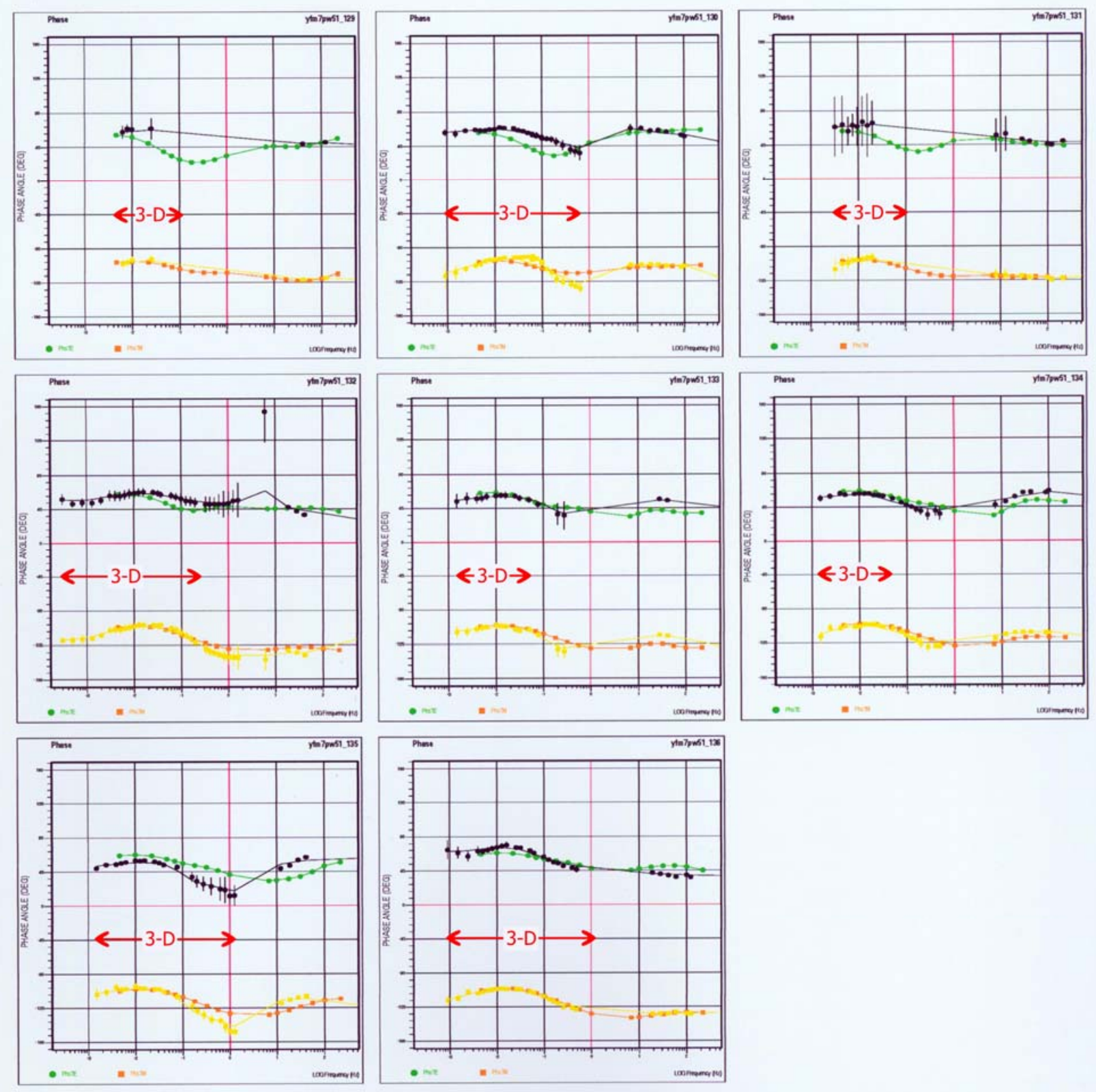

Figure A52. Profile 7, 2-D resistivity model 51 - observed (TE-black, TM-yellow) and calculated (TE-green, TM-orange) MT impedance phase curves. 3-D label indicates three-dimensional character of electromagnetic response. SP label indicates electrical resistivity structure is subparallel to the profile direction. 


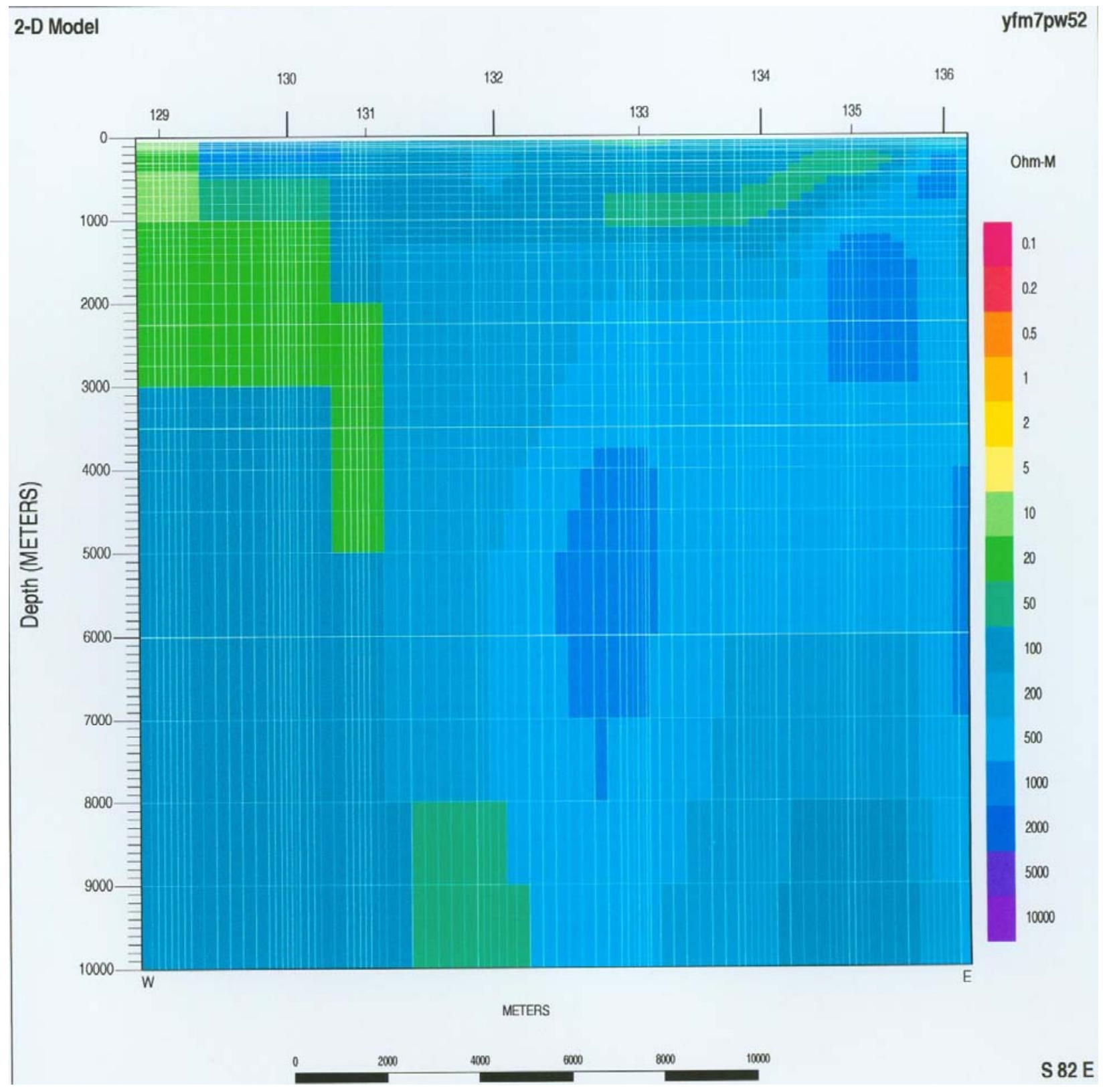

Figure A53. Profile 7, 2-D resistivity model 52 - depth section. 

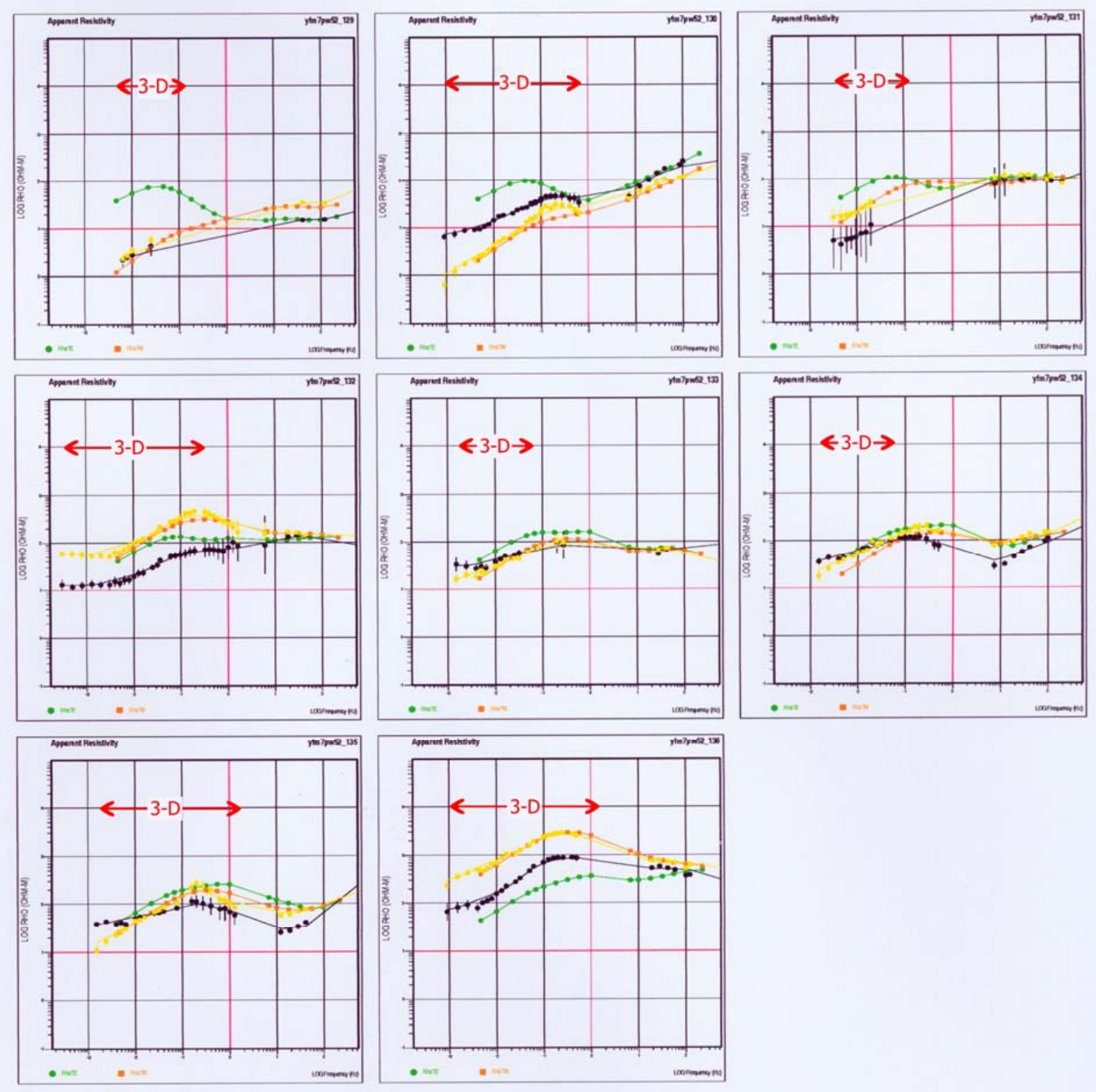

Figure A54. Profile 7, 2-D resistivity model 52 - observed (TE-black, TM-yellow) and calculated (TE-green, TM-orange) MT apparent resistivity sounding curves. 3-D label indicates threedimensional character of electromagnetic response. SP label indicates electrical resistivity structure is sub-parallel to the profile direction. 

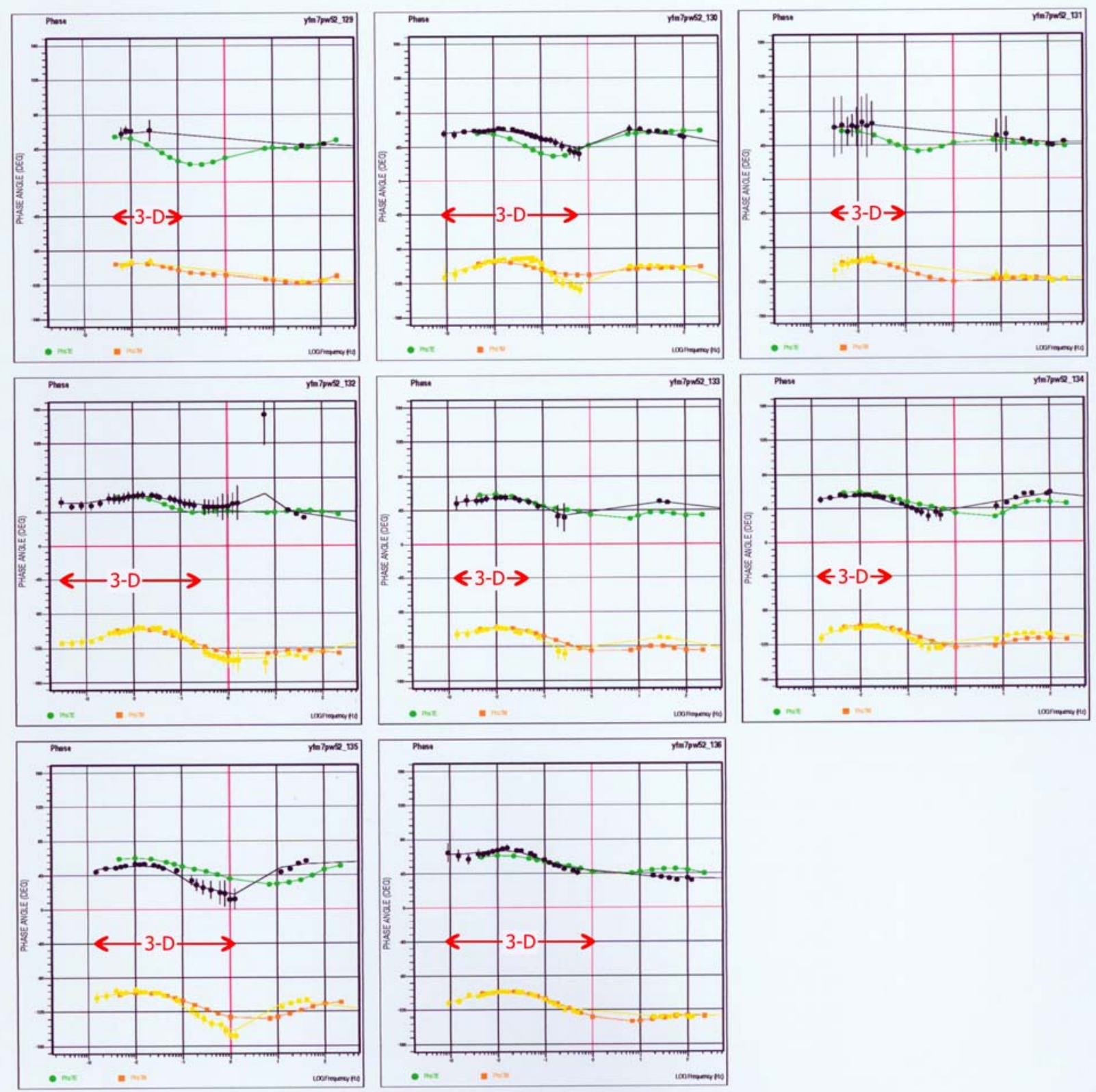

Figure A55. Profile 7, 2-D resistivity model 52 - observed (TE-black, TM-yellow) and calculated (TE-green, TM-orange) MT impedance phase curves. 3-D label indicates three-dimensional character of electromagnetic response. SP label indicates electrical resistivity structure is subparallel to the profile direction. 